\title{
COMENTARIOS Y DISCUSIONES EN EL ENCUENTRO "REFLEXIÓN SOBRE PATRIMONIO CULTURAL, COMUNIDADES INDÍGENAS Y ARQUEOLOGÍA”
}

\author{
COMMENTS AND DISCUSSIONS AT THE MEETING \\ "REFLECTION ON CULTURAL HERITAGE, INDIGENOUS \\ COMMUNITIES, AND ARCHAEOLOGY"
}

\author{
Transcrito y editado por Patricia Ayala, Sergio Avendaño, Mónica Bahamondes \\ Ulises Cárdenas y Álvaro Romero
}

Esta transcripción corresponde a los comentarios vertidos en el "Encuentro de Reflexión sobre el Patrimonio Cultural, Comunidades Indígenas y Arqueología”, que integró un grupo heterogéneo de personas del ámbito dirigencial, público, de la investigación académica y educacional, que dieron a conocer sus ideas y perspectivas relacionadas con el patrimonio arqueológico. Hubo posiciones opuestas y debates, pero siempre con respeto y valorando este primer espacio de diálogo. Esta transcripción busca exponer la variedad de tópicos, intereses y reflexiones. La tarea fue difícil, ya que distintas formas de discurso y vocabulario se hicieron presentes.

Las opiniones grabadas se presentan en un formato coloquial para facilitar su lectura, a partir de la edición de la transcripción original. Este documento tiene por fin dar a conocer la voz de personas que difícilmente pueden exponer sus inquietudes y posiciones dentro del ámbito académico y son sin duda un valioso aporte al tema central del Encuentro. Considerar lo que esperan y comentan los miembros de las comunidades indígenas del quehacer arqueológico y patrimonial significa cambiar las relaciones tradicionales entre el ámbito indígena y académico.

\section{3 de Noviembre}

Palabras de bienvenida de dirigentes de Ollagüe

Donato Gabrieli: Primero que nada, buenos días; quisiera presentarme, soy Donato Gabrieli, comunero de Ollagüe y a la vez también quisiera darles la bienvenida a todos los integrantes, profesionales, así como también a nuestro vecino país Bolivia y algunas de sus comunidades. Que tengan muy buen día.

Luis Fernández: Mi nombre es Luis Fernández, también represento a la comunidad de Ollagüe, estoy contento de que ustedes hayan llegado bien y que estén compartiendo con nosotros estos dos días del Encuentro.

Donato Gabrieli: Bueno, primero voy a empezar por la formación de nuestra comunidad. Para nosotros organizarnos como comunidad fue muy importante, de esa manera nosotros podemos tener más voz y voto, confiadamente. También nosotros somos reconocidos por la CONADI a través de la Ley 19.253, la que nos da una oportunidad de abrirnos un espacio para poder tener confianza y derechos. Derecho de que se esté haciendo este seminario aquí en Ollagüe, ya que para nosotros es un espacio muy importante, es un espacio grande para nosotros y desde ese punto de vista yo les quiero dar gracias a todos los integrantes, a todos los profesionales, arqueólogos, antropólogos y otros personeros que se me escapan.
Para nosotros esto es muy importante y de esa manera mostrar nuestras culturas. También yo quiero decir que nuestro patrimonio cultural es muy importante porque de esa manera nosotros podemos proyectarnos; que quiero decir con eso, mostrando nuestra cultura, nuestras tradiciones, nuestras costumbres y por qué no decirlo, nuestro entorno, estos bellos parajes que existen alrededor de nuestro hermoso pueblo. De esa manera nosotros a través del turismo podemos mostrar nuestra fauna, nuestra flora, nuestros restos arqueológicos y podemos, en alguna medida, mejorar nuestra calidad de vida. Porque si bien es cierto nosotros tenemos un museo, que quizás no está muy bien implementado, pero eso se puede hacer con pequeños restos arqueológicos. Pero la idea nuestra es mantener los restos in situ, o sea en su lugar de origen, nuestros restos arqueológicos, resguardarlos pero eso no quita el derecho de poder habilitar acceso para que nuestros visitantes, nuestros turistas, puedan visitar en su magnitud los restos arqueológicos y llevarse una mayor impresión, no así como poder ver los restos en el museo aunque es muy importante.

Ahora desde el punto de vista de nuestro patrimonio cultural, la base principal es la pacha mama, la madre tierra. Para nosotros eso es muy importante porque nosotros ya hemos empezado a hacer nuestros rituales, donde nosotros vamos a la tierra hacemos un pago a la tierra, hacemos ceremonias, para qué, para que de alguna manera la pacha mama nos devuelva recíprocamente, que haya buena cosecha, que haya lluvia, no cierto, y desde ese punto de vista también nosotros, por ejemplo, una de las costumbres que nosotros tenemos es el floreamiento de nuestro ganado que nosotros le ponemos en la oreja algunas flores de lanas de colores, muy hermosos y eso también es en agradecimiento del sustento que nos dan esos animales. Entonces eso es en alguna manera lo que le pedimos a la pacha mama. Y también decir la parte de la agricultura que es lo mismo y ahí nace el carnaval, la comparsa y cada integrante de la comparsa se carga una porción de la siembra, de la nueva cosecha. Entonces de alguna manera nosotros le damos el agradecimiento a la agricultura a la siembra. Y también no nos olvidamos del tata Inti porque usted sabe que una semilla no nos puede germinar, necesita tierra, necesita agua, calor y por eso siempre esta presente el tata Inti y también nosotros nos acordamos y le hacemos algunas ceremonias. Entonces eso es, y cuando nosotros al empezar un carnaval sacrificamos un ganado, entonces nosotros votamos la sangre, ahí nosotros decimos que entra a prevalecer la ciclicidad, porque en la pacha mama nace, crece, vive y muere y vuelve nuevamente a la tierra, entonces eso para nosotros es muy importante.

Yo quiero también que todos los profesionales de alguna manera nunca se olviden de nosotros, nosotros estamos muy agradecidos porque ellos nos asesoran a nosotros, porque siem- 
pre se ha dicho que la práctica con la teoría van de la mano siempre, y eso es muy importante, no se olviden de asesorarnos, por qué no decirlo en estos momentos, decirles a ustedes que aquí en Ollagüe como somos quechuas el Inka vive, así es que por favor no se olviden de nosotros.

Luis Fernández: Yo les voy a hablar de las capacitaciones que nosotros recibimos de parte de los antropólogos y arqueólogos que tuvimos acá en el museo. A mí, en particular me pareció importante saber cosas que desconocía. Una de esas capacitaciones fue acerca de cómo los habitantes llegaron a América, otra fue conocer la Ley Indígena, la 19.253, en la cual en el artículo primero se nos reconoce a nosotros como etnia quechua, y que con eso basta para que nosotros nos expresemos como comunidad y decir un poco lo que hemos callado y demostrar que tenemos tanta cultura y patrimonio cultural que explotar. Gracias a esta ley tenemos la facultad para explotar todo lo que tenemos acá en la zona. Eso más que nada sería mi parte, gracias.

\section{Presentaciones de dirigentes y profesionales}

Ximena Cruz: Mi nombre es Ximena Cruz, yo represento a la Comunidad Atacameña de Coyo. A este encuentro tenía que venir otra persona, pero él renuncio y lo estoy reemplazando yo. Tenemos a cargo un sitio arqueológico, Aldea de Tulor, hace cinco años. Nosotros comenzamos con una caseta donde vendíamos los tickets. Más adelante surgieron proyectos para construir una pasarela y un mirador. [...]

Carlos Aguilar: Saludo al pueblo quechua de Ollagüe y a toda la gente que participa en este Encuentro de patrimonio cultural. Bueno, yo me siento contento de poder participar y de conocer el trabajo también de los organizadores y creo que es una de las pocas actividades de este tipo en que participan los pueblos originarios. Soy presidente de la comunidad de San Pedro de Atacama.

Cuando decimos patrimonio cultural, ¿qué entendemos por esas palabras? Quiero citar algo que siempre nos han dicho nuestros abuelos y que es que siempre nos han indicado de no tocar $[\ldots]$. Es algo que durante todo este tiempo hemos visto, de alguna forma quizás, le hemos dado el valor de no perecible, porque no hemos hecho lo que nos han dicho los abuelos, no hemos planificado, hemos tocado todo esto.

Tampoco me voy a referir a esta cosa, no se cómo le llaman, el escudo [de San Pedro de Atacama], entonces se dice: Capital Arqueológica de Chile, bueno, para algunos. Para nosotros ha sido una forma bien dolorosa y creo que este emblema que tiene la municipalidad muestra el sentimiento que tiene el pueblo atacameño, pueblo Lican-antai, hay un cierto orgullo de tener esa capital arqueológica de Chile, [aunque] mucha gente del sector de Atacama creemos que este trabajo que conocemos como arqueológico, consideramos que es saqueo con título de todos los sitios. Y no sólo lo que es el trabajo arqueológico, sino también lo que comprendemos como trabajo antropológico, ya que mucha gente que trabaja en esas áreas se ha metido en nuestras comunidades y lo ha hecho también de una forma muy violenta. Creo que no ha habido este espacio de poder conocerse, primero que nada, es bueno pedir permiso. Por eso creo en este trabajo que están haciendo los jóvenes le dan una mirada distinta, creo que es desde ese lado importante.

Pasa el tiempo y empiezan a ser conocidos los pueblos por su trabajo entre comillas arqueológico-antropológico y después se dice revalorización de una cultura o revalorización del patrimonio, como que si los pueblos no pudiéramos o todavía no valoramos este patrimonio que tenemos. Resulta que lo valoramos, pero lo valoramos de otra forma, y se ha promovido una tendencia también en los pueblos y comunidades a trabajar en función de estos sitios con el turismo. Pero el turismo empieza con la cantidad de gente que ha llegado a los pueblos y también ha desordenado muchas cosas por no tener un cierto, no sé si control, sino más bien hablo de este encuentro, de esta mirada que nunca hubo con los turistas, sino más bien llegaron y se metieron en los pueblos y comunidades y eso también nos parece mal en realidad.

Y todo esto empieza también con estos títulos que dicen "revalorización del patrimonio cultural"; reflexionando sobre ese tema nos parece que no corresponde en realidad. Pone de manifiesto un interés económico y sabemos que este interés económico va de la mano con esta cultura minera que es una cultura de la explotación; discrepamos de una forma tan sucia que no es entregar o dar a conocer o invitar a conocer una cultura de los restos antiguos, sino de darle a esto un interés de alguna forma influenciado por la misma, por un movimiento de estudio que muchas veces está tocado por la vanidad. Y bueno, que es importante reflexionar entre todos nosotros, quienes trabajan en lo arqueológico, y en todos los "lógicos". Creo que este Encuentro es un buen acercamiento, pensamos y lo hemos constatado entre los más jóvenes, podemos ver que hay una disposición y una forma distinta de trabajar y eso tiene un valor. Creemos que hay una disposición a trabajar. Creemos que estamos hoy día acá para conversar sobre este tema y podamos discutir con algunos puntos más. Y pueden aplaudirme.

Ricardo Vilca: Buenos días, en mi calidad de presidente de la Comunidad de Quitor de San Pedro de Atacama, es un gran honor dirigirme ante todos ustedes. Hoy día es un día muy especial por estar compartiendo todos juntos temas muy importantes de la administración de la parte turística. Mi comunidad está compuesta por 53 socios, 120 personas y les traigo los más calurosos saludos a todos ustedes en nombre de ellos. Tenemos grandes proyectos como comunidad; desde el 13 de octubre del año 1996, tenemos canalizados los canales a través de proyectos, tenemos un tractor funcionando para la comuna de San Pedro de Atacama y tenemos el gran objetivo de administrar el Pukara de Quitor.

Hemos tenido algunos problemas, digamos a partir del 19 de junio tuvimos algunos percances en la construcción de baños. Monumentos Nacionales no está de acuerdo con la arquitectura, pero son todos problemas solucionables y tenemos el objetivo de que vamos a administrar y que vamos a andar bien. Espero que con la ayuda de todos los arqueólogos y de todas las personas que quieren que se administre el Pukara de Quitor podamos conseguir ese objetivo. Y como presidente de la Comunidad de Quitor, que me hice cargo el año 2000, ha sido mi sueño echar a andar el Pukara; como digo pienso positivo y lo he tirado para adelante, también me he equivocado, pero si en la vida uno piensa positivo todo lo que quiere lo consigue y espero conseguirlo para la Comunidad de Quitor y para el pueblo atacameño, porque el Pukara de Quitor es de todos los atacameños. Así es que me siento realizado por ese lado y espero con la ayuda de todos los arqueólogos y los que estudian podamos realizarlo; así que muchas gracias y gracias por compartir con todos ustedes, esto es importante y tenemos la oportunidad de crecer todos juntos. Así como dice el gobierno, si Chile crece todos crecemos, así como las comunidades indígenas vamos a crecer todos y somos capaces de administrar bien. Muchas gracias.

Roberto Mamani: Yo soy de la Comunidad de Larache. La presidenta se llama Felisa Mamani, pero no pudo venir y me mandó a mí. La comunidad recién está empezando, como pueblo chico, y estamos recién tomando experiencia para dirigir. Vine para tener nuevas ideas y tener experiencia, como dice Ricardo Vilca, de ser otro. Eso no más sería. Gracias. 
Sara Plaza: Yo (representante Comunidad Atacameña de Peine) no tengo mucho que decir, pero le agradezco a toda la gente de la organización, hemos podido participar acá para tener más experiencia y aprender muchas cosas más, porque el pueblo de Peine es muy nuevo en este sentido del turismo y este año recién empezó a funcionar un albergue que se construyó el año 2000. Con esto nos pondremos a trabajar y entender el turismo y la parte de Monumentos Nacionales y cosas arqueológicas, ya que para nosotros es muy nuevo, demasiado nuevo, recién estamos empezando a conocer. Nosotros nos hemos empezado a preocupar de la llegada de mucho turismo a nuestro pueblo y no nos ha quedado nada.

Tenemos Peine Viejo, que es muy atrayente para el turista, pero nosotros no tenemos todavía en las manos el poder sacar algo o hacer cosas bonitas que tiene nuestro pueblo. Tulán también es algo bien atrayente, pero no lo tenemos en nuestras manos, incluso ahora estamos preocupados por Peine Viejo porque en estos momentos hay geólogos, antropólogos y toda la gente que estudia estas cosas, que nos enseñaran a cómo manejarlo, cómo cerrarlo, cómo poder tener nosotros alguna entrada. Con las pinturas también, ya nosotros tenemos cerrada la parte de pinturas, pero no lo tenemos todavía todo cerrado porque no tenemos el permiso de Monumentos Nacionales. Eso les pediría mucha ayuda e información porque nosotros somos muy nuevos en esto, sabemos que llegan arqueólogos a hacer estudios pero de eso nada tenemos nosotros, ni siquiera alguna información, de qué años viene, cuánto tiempo existen esas cosas, nada de eso. Así que eso sería todo porque no tengo mucho que decir. Muchas gracias.

Herminda Varas: Yo soy la secretaria de la Comunidad Indígena de Socaire. Soy bastante nueva porque no hace mucho que me entregaron el cargo y no tengo mucho que contarles. Tengo que llevar nuevas ideas para presentar a mi comunidad. Eso no más, gracias.

Lucas Condori: Vengo de parte de la Comunidad de Río Grande. Creo que lo que estamos haciendo acá es bueno, porque de aquí yo creo que tenemos que reflexionar más ideas y reafirmarnos más como comunidad y unirnos más a los sectores sur y norte.

Yo les quería decir para muchos que no conocen Río Grande; Río Grande está de Calama a $100 \mathrm{~km}$. La mayoría somos agricultores, somos una comunidad de agricultores que está produciendo hoy en día fuertemente el ajo para dar a conocer la comuna, que eso yo creo que es bueno, estamos sembrando para la juventud, eso es lo que queremos, que la gente no se vaya de nuestros pueblos, que siempre esté, además que somos pocos. Río Grande es un poblado de alrededor de 90 o 100 personas, desde niños hasta abuelitos, pero nosotros como pueblo chico estamos bastante unidos y yo creo que con eso podemos lograr muchas cosas.

Ahora, para asimilar más nuestro patrimonio, a través de la CONADI, a nosotros nos entregaron un título, ya muchos sabemos que es publicado en Chiu-Chiu y con eso reconocemos lo que nos corresponde en nuestra comunidad, para sacarle más provecho a futuro porque lo que tenemos es bueno y tenemos que explotarlo, tenemos muchas riquezas y tenemos que ir descubriendo muchas más. Creo que gracias a esta Ley Indígena que ahora tenemos está uniendo a la comunidad y eso para nosotros es muy bueno.

Ahora en el caso del turismo, a nosotros mucho nos han invitado, SERNATUR ha ido tantas veces, pero como la comunidad no ha aceptado las razones de un principio, llevamos muy poco tiempo, ya que tuvimos ideas nuevas, gente nueva, viendo para trabajos, sacando conclusiones, porque en Río Grande tenemos muchas personas de edad. Sabemos que hay dos clases de turismo, turismo bueno y turismo malo. Entonces se ha visto todo eso y al final con la gente que fue creciendo, gente joven que se ha ido dando cuenta de lo que es el turismo, se ha ido a votaciones, la comunidad es chica de 44 personas, pero se llegó por mayoría que sí, entonces se está trabajando ya fuerte en el turismo, por un albergue; ya tenemos casi organizado los circuitos, tenemos bastante, por eso yo creo que se han ido jóvenes a cursos; entonces yo creo que es bueno y ahora nosotros lo que tenemos que hacer es más propuestas, dónde y cómo, de esto hay que llevar ideas o traer ideas y afirmarnos nosotros como comunidad. Yo creo que todos, cada pueblo merecemos un respeto y uniéndonos creo que hicimos cosas. Reconozcamos más a nuestra Ley y seamos más de lo que estamos haciendo. Eso sería con la invitación y muchas gracias.

María Teresa Planella (arqueóloga, Consejo de Monumentos Nacionales): He escuchado con atención lo expuesto por los arqueólogos y los representantes de las comunidades indígenas en esta extraordinaria oportunidad. ¿Cuál es al respecto de estos interesantes temas la mirada y cuáles son las acciones participativas desde el Consejo de Monumentos Nacionales? Vemos surgir concretamente los primeros frutos de que estén trabajando en conjunto el Consejo de Monumentos Nacionales, importantes instituciones como CONADI, las distintas instancias de gobierno regional, las universidades y las comunidades de pueblos originarios. Es un enorme avance, que demuestra también un enorme esfuerzo de las partes por coincidir y consensuar criterios, metas y procedimientos en la búsqueda de una adecuada protección del patrimonio cultural y natural de nuestro país.

Sí, se puede decir que estamos en un momento coyuntural de estas acciones compartidas y, por tanto, deben aprovecharse como una base sólida las aproximaciones alcanzadas y no permitir que se diluyan las oportunidades y perspectivas de optimización que nos ofrece al respecto este momento de encuentro en Ollagüe. El reconocimiento de la importancia de vincular el patrimonio arqueológico con las comunidades indígenas locales ha llevado a la formulación y ejecución de líneas de acción que sostiene que la administración ilustrada, económica y de divulgación, puede recaer en las propias comunidades. Es en esta dirección que se encuentran en coordinación y desarrollo algunos proyectos interinstitucionales a los que nos vamos a referir, y que reflejan que es posible concretar intenciones fuertemente compartidas por diferentes instituciones, en funciones de un objetivo común.

En primer lugar nos vamos a referir al proyecto de "Conservación, Administración y Difusión del Patrimonio Arqueológico de la Provincia de El Loa, II Región”, convenio firmado en julio de 2001, en conjunto con la Secretaría Regional de Bienes Nacionales de la II Región, la Corporación Nacional de Desarrollo Indígena (CONADI), la Corporación Nacional Forestal (CONAF), la Ilustre Municipalidad de San Pedro de Atacama y el Instituto de Investigaciones Arqueológicas y Museo R. P. Gustavo Le Paige (IIAM) de la Universidad Católica del Norte. En lo sustancial, los objetivos de dicho proyecto son los siguientes: La conservación del patrimonio arqueológico a través de la implementación de medidas básicas de protección, vigilancia y uso público de sitios del área de la provincia de El Loa. La definición de una estrategia de administración de los sitios arqueológicos, centrada en la conservación y en la coordinación de instituciones estatales, universitarias, municipio local y comunidades indígenas, planteando como una primera etapa la ejecución de un sistema de vigilancia, protección e implementación de medidas para el uso público. Desarrollar un proyecto de formación de monitores indígenas en patrimonio cultural y natural centrado en la realidad atacameña, el que se va a materializar con los programas de la actividad denominada Escuela Andina el año 2002.

El estado de avance del mencionado proyecto da resultados positivos: los convenios han sido aprobados y firmados; se 
han conseguido los fondos requeridos para el año de ejecución y se ha hecho traspaso de ellos a IIAM. No cabe duda que la orientación de la sensibilidad del quehacer arqueológico hacia las comunidades indígenas, que propiciaron en forma pionera desde la década de 1970 los investigadores del área ToconceCaspana, ha dado sus frutos, y debemos agradecer en esta oportunidad sus incansables gestiones al respecto. A su vez, es pertinente destacar el trabajo y dedicación del equipo de la Secretaría Ejecutiva del Consejo de Monumentos Nacionales para lograr dar cuerpo a tan importante proyecto.

Un segundo hito, de gran relevancia en el acercamiento a los legítimos intereses de las comunidades indígenas con respecto a su patrimonio, dice relación con la declaratoria de sitios ceremoniales de comunidades mapuches tales como canchas de nguillatun, menokos y otros, en la categoría de Monumento Histórico. Algunos de los sitios, como el "Complejo Ceremonial y Religioso de Monopaine" que se encuentra en la comuna de Padre de las Casas en la IX Región, fueron presentados oficialmente al Consejo de Monumentos Nacionales en la sesión del 5 de septiembre de 2001 por el señor Cristián Catricura, encargado del área de patrimonio de la CONADI, y la moción fue aprobada por unanimidad. Esto da cuenta de un procedimiento ágil, en conjunto con la CONADI, para responder sin dilaciones a valorizar la indiscutible riqueza patrimonial de este tipo de sitios.

Otra de las tareas del Consejo de Monumentos Nacionales, que ha significado el logro de proyectos acotados que se han podido realizar, dice relación con los Consejos Regionales, en los que tienen una definida participación miembros de las comunidades locales junto a entidades gubernamentales, a través de distintas instancias. Es el caso del Consejo San Pedro, por ejemplo, cuyo secretario ejecutivo es atacameño; y el Consejo Rapa Nui, que incluye la significativa e irreemplazable cooperación del Consejo de Ancianos de Isla de Pascua. El objetivo de estos consejos locales es proveer a las comunidades de un espacio de participación activa en opiniones, sugerencias, revisiones y observaciones que nazcan desde dentro de la propia comunidad, de tal modo que redunden en que éstas sean las beneficiarias directas de los proyectos sobre patrimonio cultural y natural que se configuren en el área.

Quisiera concluir agradeciendo a los organizadores de este encuentro no sólo por la invitación cursada al Consejo de Monumentos Nacionales, sino principalmente por permitirme compartir este intercambio de ópticas tan sentido y profundo, lleno de compromisos contraídos hacia trabajar por aún mejores nexos y entendimientos con las comunidades y su patrimonio.

Cristián Catricura (Corporación Nacional de Desarrollo Indígena): [...] de acuerdo con la reforma procesal se hizo toda una etapa de investigación a cargo del fiscal en la cual nos da la orden a nosotros para poder investigar y luego incautar. Se antecedió a eso todo un proceso educativo que se hizo en la reforma y se hizo caso omiso. Por tal motivo, por primera vez en la historia, recuperamos 600 piezas del patrimonio cultural del pueblo mapuche en Temuco y en Santiago recuperamos alrededor de 200 piezas, entre ellas, cosas que son de incalculable valor para los mapuches: dos rewes vendidos en millones en una galería en Providencia. No pudimos hacer nada por los demás pueblos, ciertamente estaba ahí a la venta su patrimonio, porque la reforma procesal no nos permitía y el fiscal, sin la orden del juez de garantía, decía bien claro que era solamente para piezas históricas mapuches.

Con mucho temor actuamos al principio porque veíamos que eran grandes intereses económicos, topamos a ellos, pero los recuperamos. En este momento el juzgado de garantía lo puso en custodia en el Museo Regional de la Araucanía.

Vemos que a los elementos que yo describí anteriormente, como la ley, hay que saber darle una interpretación para que el indígena y su comunidad puedan recuperar lo suyo, lo propio. A la fecha hoy tiene mucha cautela la gente de la novena región a cualquier huaquero, como ustedes le dicen, cualquier traficante de los bienes culturales del pueblo mapuche. Eso esperamos proteger y cautelar para todos los pueblos indígenas. Entonces, tiene que haber una educación, un proceso educativo hacia todas estas personas, como por ejemplo en Perú, donde dice bien claro en los aeropuertos y en las Aduanas en un afiche: "Cuidado al sacar cualquier pieza patrimonial indígena, porque está castigado por ley", y eso significa cárcel si alguien toma este bien cultural. El proceso educativo significa invertir y educar a la población. Durante el transcurso del año 2002 nosotros vamos, conjuntamente con el Consejo de Monumentos Nacionales, a invertir en educación, educación para que se cautele este patrimonio, que sepa la gente lo qué es este patrimonio cultural y en que se puede proteger.

[...] No optamos por ser castigadores, del criterio que hay que recuperar todo, más bien hay que conversar con la comunidades, hay que conversar con los dirigentes del pueblo indígena, hay que educar para que no sientan que el patrimonio nuestro, que es también religioso y cultural como lo dije yo, es llegar y sacarlo de cualquier forma o de mantener en colección. Nosotros sabemos que las colecciones están, tanto en Europa, en América del Norte o acá en Chile, la ley lo permite; pero cómo nosotros conversamos con el indígena, cómo nuestro Consejo Nacional conversa para modificar estas leyes, cómo interpretarlas, o que de ahora en adelante, si están esas colecciones que se mantengan pero que no se acrecienten de ahora en adelante. Eso es lo que nosotros esperamos: proteger el patrimonio cultural de las poblaciones indígenas mediante tres propuestas.

Primero, fomentar la participación de las comunidades indígenas en la protección y administración de los sitios arqueológicos históricos en concordancia con la Ley de Monumentos Nacionales, con organismos pertinentes como CONAF y Bienes Nacionales.

Segundo, promover la preparación de técnicos indígenas en arqueología y restauración de bienes históricos. Para que vean que estamos preparados, que llegue un científico y no que la comunidad no esté preparada. Preparémonos, como bien lo decía la arqueóloga del Consejo de Monumentos Nacionales, la Escuela Andina para preparar monitores en el manejo patrimonial, entonces no va haber una excusa para decir que no estamos preparados.

Tercero, mantener el culto de las comunidades indígenas en torno a sitios de valor patrimonial o arqueológico que tengan un significado para la cultura, desde un punto de vista religioso, para que los rituales no sean afectados o profanados por turistas que visitan el lugar. Eso es fundamental, no interrumpir el vivir diario de un indígena y de sus ceremonias, que no sean una recreación como se da en otros países. Que no sea solamente una recreación por un recurso económico, entonces ya no estaríamos haciendo una ceremonia en sí, sino que estamos haciendo una teatralización de una ceremonia.

Que se incluyan los criterios religiosos y culturales en la conservación e investigación científica para limitar el uso turístico de sitios arqueológicos que las comunidades así lo estimen de acuerdo a sus costumbres ancestrales. Damos el ejemplo concreto de los tratados que ha hecho el gobierno de Australia con los pueblos indígenas y el gobierno de Estados Unidos con algunas tribus y comunidades indígenas. El antecedente internacional está ahora con nosotros como bienes nacionales, nos manejamos desde este punto de vista y podemos trabajar para que se cautele y se proteja.

En todas las presentaciones se ha hablado del patrimonio que es invaluable, imperturbable. Como dije anteriormente se ven como objetos determinados en peso o en dólares y eso está hasta el día de hoy. Ahora, cómo calculamos eso, es propio de las comunidades indígenas que deben plantear a las autorida- 
des competentes, como se ha dicho acá, municipalidades, gobiernos regionales, la CONADI, sus representantes legislativos que así lo estimen conveniente.

Eso es lo que se debe tratar de establecer ahora en concordancia con cada pueblo; cada pueblo tiene su forma de ser, no podemos establecer con parámetros del pueblo mapuche lo que deberían de hacer el pueblo rapanui, son totalmente diferentes. Si ellos operan así o lo hacemos todos igual, pero la idea es proteger, proteger de ahora en adelante ya veremos cómo, pero hay que conversarlo. Yo sé que las comunidades están inquietas, las comunidades lo tienen presente, ya es tema de conversación de ellos, pero cómo nivelamos el nivel de ingreso turístico con la producción, hasta dónde pasamos a llevar eso y también el estudio científico. Hay que conversar con las comunidades, no vaya a ser que usted le diga a una comunidad: bien vamos a establecer con ustedes y van a trabajar ustedes cinco meses y le vamos a pagar tanta cantidad en dólares y la comunidad dice sí; pero luego de eso viene un par de años y sus hijos y sus nietos ven que perdieron todo su patrimonio, ya que no quedó nada de eso y ¿donde está la conciencia de la comunidad? A eso apelamos.

Como CONADI responsablemente se los digo: nosotros vamos a congelar de acuerdo a las peticiones de las comunidades indígenas, ellos son los que tienen la voz y quienes no tienen que canjear. Ya nos planteó un pueblo determinado cautelar su patrimonio, si plantean otros pueblos nosotros los vamos a cautelar igual. Justamente estamos atentos a todo lo que pase en el medio nacional. Eso era lo que quería conversar con ustedes.

\section{Discusión}

Carlos Aldunate (arqueólogo, Director Museo Chileno de Arte Precolombino): Se trata de crear una etapa de discusión, claro que no es "agarrarse del moño", sino que es una etapa en que todos tenemos oportunidad de presentar lo que nosotros creemos, lo que nosotros opinamos, y para un orden, tratemos de presentárselo a la mesa, a nosotros, y no hacer discusiones entre dos personas porque de eso no se puede sacar mucho y tampoco se puede escuchar bien. Así es que vamos a tratar de comenzar esta discusión.

Para iniciarla me gustaría decirles primero que yo como no soy de los organizadores, yo venía con mucha esperanza de esta reunión pero tampoco sabía mucho a lo que venía, y en realidad de esta primera etapa que hemos visto aquí, por lo menos mi impresión personal es que he quedado tremenda y muy gratamente impresionado de todo lo que aquí se ha dicho; encuentro que las comunidades y los investigadores se han expresado con una enorme claridad y con mucha honestidad, con mucha franqueza en sus posiciones, y eso yo creo que es vital para este encuentro que pretende justamente eso, un acercamiento entre las comunidades, entre los investigadores y entre algunas instituciones y autoridades tan importantes como el Consejo de Monumentos Nacionales y la CONADI que están aquí presentes.

Yo, por mi lado, he anotado aquí ciertas cosas que podrían ser el inicio de alguna conversación y puede haber varias otras que ustedes tengan también en mente, no es verdad, esto no quiere limitar la discusión, sino que quiere solamente abrir un espacio. Por ejemplo, yo vi dos posiciones, las dos muy respetables sobre el patrimonio, una posición que tiene mucho que ver con el turismo y con explotar el patrimonio como un recurso turístico, cultural y económico a la vez, y por otro lado, una posición de tomar el patrimonio como algo que el turismo también podría perjudicar. Estas dos posiciones son muy interesantes y creo que todos de alguna manera u otra pensamos lo mismo, pensamos que estas dos posiciones pueden ir hacia una cosa común, que el turismo no perjudique el patrimonio por un lado y que el patrimonio a la vez sea un recurso, porque como muy bien se dijo aquí, hay una cosa muy bonita del patrimonio para las comunidades y es que las comunidades se están mostrando a sí mismas a través del patrimonio, se están dando a conocer a través del patrimonio. Entonces, estas dos posiciones podrían servir como para iniciar algo.

También he visto cosas que me han parecido muy extraordinarias, que se han mostrado aquí como experiencias que ya han sucedido, del Consejo de Monumentos Nacionales, CONADI, de cómo las comunidades pueden ser actoras, cómo las comunidades pueden ser verdaderos actores y liderar ellas el proceso de su patrimonio; hemos visto casos en que las comunidades han iniciado la restauración, han pedido o concurrido a las autoridades, hemos visto casos en que las comunidades han declarado sitios que les interesan como patrimonio cultural y como monumentos nacionales de Chile, están inscritos dentro del patrimonio oficial de Chile. O sea las comunidades pueden cautelar, pueden preocuparse de su patrimonio, hay un sistema legal, hay una vía legal institucional para que las comunidades tengan este acceso, eso a mí me pareció que es otro punto en el que se pueden intercambiar opiniones.

En este momento me acuerdo cuando estaba en el Consejo de Monumentos Nacionales y recuerdo que la primera Comisión Regional del Consejo de Monumentos Nacionales fue la de San Pedro de Atacama, porque fue la comunidad de San Pedro de Atacama la que se preocupó de tener una comisión regional de Monumentos Nacionales, así como la hay en San Pedro puede haber también en otros lugares, también ahí hay un resorte de la comunidad para intervenir. Y en la relación de las comunidades con los investigadores, lo que más he visto a través de lo que se ha dicho en la mañana es esto de la capacitación, de la información, de la comunicación de los datos, también este es otro punto muy necesario de discutir. Tengo más o menos esos tres puntos y doy la palabra.

Donald Jackson (arqueólogo, Presidente Sociedad Chilena de Arqueología): Bueno, yo creo que sería bueno insertar en la discusión lo que es el robo y el tráfico de piezas arqueológicas.

Carlos Aldunate: Lo estábamos pensando y creo que ahí no va a haber discusión; pienso que esto puede ser una conclusión de mañana, porque es demasiado relevante, yo pienso que estamos todos muy de acuerdo con eso.

Carlos Aguilar: Por qué tendría que ser una conclusión cuando se ha visto el problema de un solo lado y yo creo que es importante ver el problema desde otro lado como lo hemos planteado en la mañana; ver el tráfico no solamente a partir de lo que sale fuera del país, sino también ver el tráfico como el tomar ilegalmente, principalmente de las excavaciones que se han hecho. Mirarlo de ese lado también, que haya una reflexión sobre el tema.

Carlos Aldunate: Claro, eso ya no sería tráfico ilícito de bienes culturales, o sea, sería ilícito desde el punto de vista de las comunidades probablemente, entonces ese es un tema; la verdad, que lo pusieron, que yo lo tengo aquí, para tratar con los investigadores no sólo lo de la comunicación y difusión, sino que también sería ya la excavación de los cementerios, que fue lo que aludiste esta mañana. En el fondo es eso, y de qué se hace con estos bienes que los arqueólogos recuperamos en las excavaciones, qué hacer con ellos, entregárselos a la comunidad, hacer museos regionales, ese tipo de cosas y también la conveniencia de excavar o no excavar ciertos lugares sagrados.

Sergio Avendaño (antropólogo, Proyecto Ollagüe): A nombre del proyecto Ollagüe también me siento muy gratificado en el 
sentido de que para nosotros es muy importante esta instancia, realmente no teníamos la certeza de cómo iba a resultar, nos parece que ha resultado muy bien. En relación al punto que tocaba Carlos Aguilar creo que, y es parte de nuestro proyecto, se debe establecer esta nueva relación entre las comunidades con el mundo científico arqueológico-antropológico. Yo creo que existe un diagnóstico acertado de parte de las comunidades en términos de que en las investigaciones que se han hecho, no podemos englobarlas a todas obviamente, porque hay muchas excepciones, no se ha establecido un canal de comunicación fructífero entre arqueólogos, antropólogos y las comunidades indígenas que se han estudiado. Creo que es un punto global que permanece en toda la discusión que se ha producido.

Donald Jackson: Quisiera agradecer a los organizadores su gentil invitación y al mismo tiempo la acogida que nos ha dado la comunidad de Ollagüe y quisiera hacer un comentario general. Me parece tremendamente importante estar reunidos aquí porque de alguna manera nos reconocemos como un país, como un pueblo diverso. Creo que esto es un ejemplo para comenzar a aprender a vivir en comunidad, a vivir en la diversidad y el vivir en la diversidad implica que compartamos opiniones comunes y otras opiniones que no son comunes; esto también implica que en nuestras posiciones tengamos que ceder y en otras posiciones no. En el fondo no esperemos que nuestras posiciones las logremos ganar en su totalidad, creo que cuando nos reconocemos en la diversidad también tenemos que reconocer las inquietudes y las necesidades del otro y a veces esas necesidades del otro implican que nosotros cedamos.

Creo que este encuentro es un primer paso en este diálogo, creo que la comunidad indígena, la comunidad arqueológica, la comunidad antropológica, la comunidad nacional tienen conflictos y lo primero que tenemos que hacer es reconocer esos conflictos llanamente y dialogarlos, creo que ese es el primer camino a través del cual podemos comenzar a solucionar aquellos conflictos.

Victoria Castro: Mi nombre es Victoria Castro, soy profesora, arqueóloga también, yo quisiera ir a una cuestión bien puntual que tiene que ver con la vuelta de mano, la vuelta de mano en términos de lo que nosotros estudiamos como interesados en la humanidad, no hay solamente aquí arqueólogos y antropólogos, está también la gente indígena, que es el conocimiento y la curiosidad que nos reúne a todos, también a los pueblos. Están también colegas que son personas valiosísimas para la preservación del patrimonio tangible, que es la gente que se dedica a la conservación, restauración, a cómo cuidar, cuestión que los arqueólogos materialmente no sabemos. Pero finalmente a todos nos reúne un interés por aquello que construye la identidad de los pueblos originarios, pero también de esta nación que se llama Chile hoy día y somos parte de una nación mayor: el mundo andino.

Ahora volviendo con el tema de la vuelta de mano, nosotros hacemos un tipo de trabajo muy concreto que después se vierte en publicaciones. Estudiamos patrimonio tangible e intangible, nos interesa, de acuerdo a los enfoques que estudiamos, lo material, pero también la filosofía que está detrás de la comprensión del mundo que cada pueblo tiene y de cómo integra la naturaleza dentro de su cultura. En este sentido, si nosotros queremos valorar su patrimonio más bien tangible del pensamiento, queremos también entregar un aporte en mostrar cómo la ciencia universitaria, llamémosla así, pueda ser paritaria de la ciencia indígena. Por qué, porque a los pueblos y a la ciencia universitaria, a ambos sistemas de conocimiento, les sirve esta forma de exponerlo ante una oficina extranjera, para hacer tal o cual estudio.

Por lo tanto, hay un drama con lo que hacemos y con lo que recepcionan las comunidades, es el tema de que a nosotros nos pueden dar un pasaje, dar para comer en terreno, cosas así, pero nunca tenemos un organismo que nos dé un recurso para publicar y distribuir. Entonces, el sistema nacional que tiene las revistas para publicar que son los museos, las universidades, una vez que nosotros entregamos el material sobre lo que hemos estudiado en las comunidades para que se publiquen, nos entregan de vuelta uno o cinco ejemplares, nosotros de nuestro bolsillo hacemos un esfuerzo, hacemos diez ejemplares más y mandamos a las comunidades, pero no basta.

Entonces, quizás mañana en la mesa redonda deberíamos ver cómo los sistemas nacionales, a lo mejor un aporte del área de patrimonio de la CONADI, que sé yo, nos diera para remitir esto y ellos lo pueden distribuir más masivamente a los actores precisos, para que cada comunidad tenga los estudios que nosotros hemos hecho, aquellos que dejamos en el papel, que queda fijo en un tiempo. Creo que es muy importante, es un tema muy concreto, pero creo que es un tema extremadamente fundamental para la comunicación y esta educación dialéctica que tenemos entre estudiosos formados en la universidad y estudiosos formados en la vida de cada comunidad. Bueno, sobre eso hay mucho más pero quería dejarlo un poco para que se pusiera mañana.

Mauricio Uribe: Yo soy arqueólogo, miembro de la Sociedad Chilena de Arqueología y también creo que así como dicen Donald y Vicky hay que reconocer que este es un país diverso, que hay una identidad, que somos todos partícipes de este espacio y de su patrimonialidad, así como también tenemos que devolver la mano en términos de lo que nosotros producimos, de lo que hacemos. Pero también obviamente pedir disculpas a todas las comunidades y a toda la población indígena originaria si en algún momento se han sentido pasadas a llevar o uno lo ha hecho mal. Lo que quiero intentar decirles es que hay que reconocer que hay un proceso, un proceso en que la ciencia se va haciendo, un proceso en el cual los científicos se van formando y la arqueología es una ciencia que se formó en Chile en los años setenta. Antes eran personas que por sus intereses y por sus propios medios hicieron arqueología; lamentablemente por esos intereses, por esa curiosidad, por el esplendor de las culturas originarias, por el maravillarse con esa cultura originaria o esas culturas originarias de nuestro país cometieron errores. Hoy día existe una formación universitaria, hoy día existe una Sociedad Chilena de Arqueología, existe una ética en la cual se está intentando reconocer que existe un proceso en el cual los arqueólogos tenemos toda la intención de transformar nuestras formas de acercarnos al pasado de nuestros pueblos originarios y donde no hay mala intención.

En estas reuniones la idea es aportar con lo que nosotros sabemos hacer, no sabemos hacerlo de otra manera, los conservadores lo saben hacer de otra manera y así los múltiples especialistas. El patrimonio se construye en la medida que es reconocido en la diversidad de intereses que existen. Porque aquí hay intereses económicos, hay intereses científicos, hay intereses de las poblaciones originarias y si no existieran esos intereses no existiría una necesidad de proteger ese patrimonio. Ese patrimonio tiene valor porque existen esos intereses y en ese sentido entendernos mutuamente.

Pero también corresponde comprender nuestra historia como ciencia, como disciplina. Nuestra intención es hacerlo lo mejor posible, no es destruir, no queremos destruir ni atropellar a nadie, es poder hacer un trabajo serio, científico, bajo un método y ojalá las mismas comunidades pudieran decirnos cuál es la metodología que ellos prefieren que ocupemos. En la medida en que nosotros seamos capaces de mostrarles nuestra metodología de trabajo, en la cual obviamente no es necesario siempre excavar, no es necesario siempre abrir las estructuras o sacar las tumbas, hay múltiples otras opciones y posibilidades, para generar y definir en conjunto los canales regulares, porque cla- 
ro, de parte de muchos de nosotros hay una intención por acercarnos, por compartir nuestro conocimiento, pero uno nunca sabe a quién llegar, con quién hablar, con quién comunicarse, por dónde deben pasar todas estas discusiones y estas conversaciones, y en ese sentido creo que sería prioritario preocuparnos por los canales que articulen, vías regulares que articulen nuestros múltiples intereses, esos múltiples intereses que dan valor a nuestro patrimonio y que lo constituyen. Y por sobre todo muchas gracias a todos y a los organizadores por habernos invitado.

Patricia Ayala (arqueóloga, Proyecto Ollagüe): Lo que yo quería decir es que sin duda se ve una necesidad de parte de las comunidades de que nosotros como investigadores entreguemos la información con que contamos al hacer investigaciones arqueológicas. Pero quisiera que la comunidad sepa que también hay una necesidad de parte de nosotros como investigadores, de algunos quizás, de buscar un sentido más social a lo que estamos haciendo en términos de que haya un producto más directo de nuestras investigaciones, porque nosotros difundimos nuestro conocimiento en los congresos arqueológicos y demás, pero también queremos ver en qué medida nuestra disciplina, nuestra carrera, puede aportar en términos más concretos a la sociedad en general. Aportar en la construcción de sus identidades yo lo encuentro valioso y quiero expresarles que también es una necesidad de los investigadores este tipo de acercamiento.

María Teresa Planella: Yo soy arqueóloga, en el fondo quisiera dar una opinión bien personal. Yo he trabajado toda mi vida profesional en la zona central de Chile. En esa región no quedan comunidades indígenas, por lo tanto, que ustedes tengan la posibilidad de trabajar en conjunto con estas poblaciones vivas, que tienen sus ancestros en cada una de las comunidades, yo encuentro que es algo maravilloso, es un tesoro que ustedes debieran aquilatar y tratar de trabajar en conjunto, con una amplitud, tal como decían mis colegas, que va más allá de las cosas personales, de las cosas políticas, de las cosas que atañen a todas nuestras poblaciones, yo quisiera agradecer esto porque a mí me ha enseñado mucho. Es primera vez que tengo la oportunidad de participar en algo así y pretendo que a futuro ojalá que mi cooperación desde el Consejo de Monumentos, o desde donde sea, pueda ser útil para todos ustedes.

Wilson Galleguillos (Comunidad Atacameña Chiu-Chiu): Hermanas, hermanos, bienvenidos, un saludo muy especial, con el permiso de la madre tierra me dirijo a todos ustedes. En primer término he escuchado con mucha atención, me quedan muchas dudas, dudas en el sentido de que por ejemplo se dice que se trabaja en conjunto con las comunidades, sin embargo muchas veces se toman determinaciones con derechos públicos como es el caso aquí de la señora de Monumentos Nacionales, CONADI, CONAF, entre otros; sin embargo allí no se consideró la participación de la comunidad.

Ahora si bien es cierto hay un representante atacameño, pero en ningún caso representa a la comunidad como tal, así es que ahí hay que tener mucho cuidado. Por otro lado, también se habla mucho de patrimonio arqueológico, sin embargo, día a día yo veo que hay gente con muy buena intención y también hay gente con muy mala intención que le hace mucho daño al pueblo atacameño. Es decir, hay mucha gente que hace cosas que no debiera hacer. Me da mucha pena cuando veo arqueólogos que se lucran con nuestra cultura, que recorren el mundo hablando de la cultura atacameña; eso yo creo que no debe ocurrir nunca más, así es que yo pienso que estos talleres y estos encuentros son muy importantes porque deben marcar el inicio de que nosotros somos personas y no meros números, estamos vivos, una cultura que está presente en todo instante.
Es cierto que hay un conocimiento ancestral, como también uno técnico-científico, pero yo creo que ambos deben respetarse mutuamente. A mí no me enseña un profesor, sin embargo, me enseñan los espíritus de mis abuelos, eso también es sabiduría, es conocimiento, día a día yo hablo con los árboles, el agua me enseña cosas, las piedras me protegen, el árbol me da sombra, el agua me quita la sed, y eso igual es conocimiento. Quisiera finalizar diciéndoles que en el proceso que hay en el trabajo arqueológico-antropológico, hay que tener mucho cuidado porque yo veo que se vienen a hacer estudios y después se llevan la información y no la entregan como es debido a las comunidades, como es el caso del turismo, que se entregan diferentes fechas, bueno, y no llegan nunca a un acuerdo, por lo tanto el turista que nos visita se va con diferentes fechas y por último dice a este no le creo y a ese sí le creo.

También hay que tener mucho cuidado porque en la etapa de la excavación muchas veces ocurre saqueo, y mi pregunta es esa: ¿Lo que se llevan llega después a la comunidad?, ¿dónde quedan después esas piezas?, ¿quién se lucra con ello? Entonces yo creo que la tarea es muy grande, demasiado grande, así es que yo les insto a que sigan trabajando igual, pero por favor, les pido por favor, que antes de pisar la tierra o hacer una excavación hagan el pago correspondiente a la pajta joiti, aquí en Atacama no es pachamama, con mucho cuidado pídanle permiso que la tierra está viva. Aquí muchas veces vienen personeros con títulos de doctorados, master, pero la naturaleza no conoce esos títulos, ella conoce el respeto y la humildad. Muchas gracias.

Ángel Bravo: Yo voy a poner el énfasis en dos cosas que creo que se han tocado horizontalmente, por un lado está el patrimonio cultural, el patrimonio de los atacameños, de los quechuas y todo el resto de las etnias en Chile que tienen un "patrimonio cultural viviente" y no es una palabra mía, sino que es una definición que hace un amauta peruano que en algún momento estuvo en San Pedro de Atacama. El habla sobre el valor que tiene, por ejemplo, para un arqueólogo, un antropólogo una vasija, por así decirlo, si esa vasija se rompe el antropólogo o el arqueólogo lo sentirá porque dejará de percibir algún elemento intangible o tangible del pasado, pero al romperse esa vasija se está perdiendo algo del patrimonio ancestral de la gente, entonces hay que tener mucho cuidado en eso. El patrimonio cultural viviente en general no es considerado, aquí los colegas arqueólogos han hecho una reflexión en torno al mea culpa, esa vuelta de mano, yo en general no he trabajado como arqueólogo en esta zona, sino más bien como difusor de la cultura y me he dado cuenta de que las comunidades están aburridas, están choqueadas, me he dado cuenta también en las múltiples salidas que he tenido allá mismo, porque yo tengo esa suerte, de que mucha de la información etnográfica que se maneja principalmente, es una información que las comunidades han dado a los arqueólogos o a los antropólogos porque ellos llegan preguntando cosas preconcebidas, y a mí muchos me dicen: Don Ángel mire, en tal momento llegó tal personaje y nos preguntó por tal cosa y nosotros le respondimos lo que ellos querían que les respondiéramos; y es así como yo creo que de la escasa etnografía que se ha hecho en esta zona, por lo menos el cincuenta por ciento no corresponde a la realidad.

Yo creo que también aquí se habló de humildad, los cientistas sociales, los arqueólogos y antropólogos no tienen esa humildad, ellos por estar en una zona una semana, dos días, después aparecen con los estudios y esos estudios no reflejan la realidad, entonces ese es un tema que es conveniente cuidar.

Creo que aquí el énfasis no está ni en la teoría ni en la metodología arqueológica, para eso hay bastantes manuales que lo van a decir muchísimo mejor que yo, pero sí el énfasis debe estar en la práctica arqueológica, y la práctica arqueológica tiene que ver, como decía Vicky, con el uso de la información, que 
después de los congresos, de las reflexiones, esa información llegue a la gente. Yo me he topado también allá en San Pedro como profesor tratando de trasladar ese lenguaje críptico que empleamos los arqueólogos, trasladarlo a los alumnos y al público en general, es un tremendo problema, cuesta, los alumnos no entienden. Cuando yo los llevo al Museo en San Pedro de Atacama: Profesor, ¿qué es un bifaz?, ¿qué es tal cosa? Entonces ahí es que yo creo que los arqueólogos mucho tienen que hacer, hay que traspasar los conocimientos con sencillez, no perdiendo la esencia sino con sencillez.

Otra de las cosas que debería hacer la arqueología en su práctica cotidiana, en este uso que se hace del pasado, es ser menos elitista y estar con la gente, con las comunidades, tener conferencias que sean especialmente para las comunidades en este caso y por qué no, los museos también. Está claro que el patrimonio cultural o el remanente del patrimonio cultural es trabajado por arqueólogos, por historiadores y por conservadores, pero entendamos de una vez que esto sale de las propias historias cotidianas y es ahí donde están fracasando en estos momentos. Aquí se ha hablado de la información, es cierto, cuando vienen los turistas acá, yo me he topado con eso porque yo he hecho turismo, dicen: "Pero a mí me han dicho tal cosa, pero a mí me han dicho tal otra, y bueno, ¿cuál es la verdad?" La verdad se supone que la tienen los investigadores que están trabajando, pero como el manejo de la información está tan desvinculado con la realidad social es ahí donde se producen los problemas.

Yo me recuerdo que el año 1995, cuando comencé a hacer clases en San Pedro, se realizó el Congreso de Arqueología de Copiapó y mandé una ponencia sin ninguna pretensión científica ni nada, que se llamaba "Arqueología en el aula". Esa ponencia la rechazaron, hasta el día de hoy yo no sé por qué, cuáles fueron los motivos y precisamente mi experiencia allí era cómo yo, como profesor de historia y como incipiente arqueólogo, trataba de pasar esta información que estaba en los museos, que estaba en los textos, a los alumnos y eso quería entonces. Y bueno no fue posible, después he seguido trabajando en esta senda porque creo que la experiencia que cada uno puede tener en las comunidades es valiosa. Además yo soy calameño, no tengo el color de piel de mis hermanos atacameños, pero yo me siento atacameño, porque Calama es un reducto atacameño. Entonces quizás yo he estado más cerca de ellos que de la ciencia, de hecho yo me he perdido de la ciencia arqueológica hace muchísimos años y lo que he venido a aportar hoy día es con mucha humildad y la verdad es que debemos reflexionar y poner los puntos ahí.

Bueno, el turismo, repito, la tríada turismo-cultura-arqueología, eso es lo que nos debe convocar, evidentemente es bueno decirnos las cosas, pero es bueno ya no tanta palabrería, sino sacar conclusiones que sean efectivas. Echo de menos, por ejemplo, si se dice que en San Pedro de Atacama se formó Monumentos Nacionales local, por qué tienen que venir las respuestas de Santiago. Entonces, que está pasando acá, qué pasa, por qué alguien del Consejo de Monumentos Nacionales plantea que destruyan o cambien de sitio esto sabiendo que ese es dinero que viene del Estado, no dilapidemos los recursos porque la CONADI, aquí hay representantes de la CONADI. Yo he escuchado con atención al hermano mapuche y veo, cierto, en las leyes todo el reglamento que también mencioné, pero hay una cosa que no está solucionada y debemos evidentemente poner el acento ahí para que de una vez por todas seamos todos amigos, yo sé que es difícil, los personalismos es complicado sacarlos, pero el espíritu que yo siento esta mañana es de total fraternidad.

Francisca Greene: Buenas tardes, soy antropóloga, vengo de San Pedro de Atacama y he trabajado durante varios años en algunos proyectos de desarrollo o en diagnósticos para proyec- tos de desarrollo. Quisiera hacer una reflexión con respecto al tema del turismo en el cual también estuve desempeñándome como empresaria turística, más o menos conozco el tema desde dentro. No sé qué es lo primero, si fue que las comunidades dijeron queremos trabajar en turismo o si llegaron por montones los proyectos turísticos a San Pedro. En San Pedro, como ustedes saben, hay un boom turístico muy grande y si las comunidades indígenas han dicho quiero administrar un sitio, quiero proteger algo o quiero desarrollar un albergue o algo la respuesta de instituciones, tanto públicas como privadas, son diez proyectos encima.

Ha sido algo que se ha dado de manera muy fuerte y con mucha presión, diría yo. Me tocó trabajar en un diagnóstico de SERNATUR y mientras íbamos a una comunidad a hacer una reunión nos topábamos en el camino con dos organismos más que estaban haciendo proyectos muy similares, entonces es un tema que se está tocando muy fuerte en San Pedro. Ahora, qué me preocupa a mí de este desarrollo turístico, es que se está implementando ya una serie de iniciativas, los albergues comunitarios, la Fundación Chile con albergues más enfocados a familias, la CONAF con las administración de las reservas nacionales y las comunidades, como ya se ha dicho antes, lo han dicho varias personas que han participado, tienen un descontento, existe una desilusión producto de la falta de traspaso de información, producto de que no hubo participación, de que los proyectos no han tenido un impacto, bueno son muchas las razones. Entonces, yo veo a los dirigentes de las comunidades que han planteado varios requerimientos para trabajar el turismo y dentro de los cuales el primero y el más importante es que el turismo no cambie la forma de ser de las comunidades, que no nos impacte nuestra forma de ser, sino que todo lo contrario, que se potencie esto, ojalá que con el turismo podamos cultivar más, podamos recuperar nuestras técnicas, podamos hacer arreos de llamas con los turistas y nuestras llamas puedan tener un mayor valor agregado, podamos mejorar la calidad de nuestros ganados, que se potencie eso.

Pero hay un grave problema de falta de información, como decía; entonces las comunidades están en espera de ver los resultados de estos proyectos que se vienen encima, para ver si entran o no entran al turismo, a mí lo que me preocupa es que no ha habido un espacio de reflexión por parte de las comunidades de ver cuál es esta forma que no se quiere cambiar, ver cuál es lo que decía esta mañana Carlos [Aguilar], o sea, queremos administrar un sitio o queremos protegerlo o no queremos acercarnos porque ahí están nuestros antepasados o qué se yo. No se ha dado este espacio para que las comunidades puedan ver realmente cómo quieren enfrentar el turismo y si ellos lo han conversado en algún momento a través de algunas reuniones, los programas y proyectos que se están implementando en este momento tienen un fin, hagamos que las comunidades tengan más experiencia en torno al manejo económico de todo este asunto. Pero se complica esto en Socaire o en los albergues, se va a dar servicio de alojamiento, servicio de alimentación. Pero las comunidades no pueden matar un cordero porque las reglas sanitarias lo impiden, o en Cámar se va a poner un albergue pero los pozos sépticos están colapsados. O sea, hay una serie de condiciones previas que se tienen que tomar en cuenta que no se están tomando y que producen que la participación comunitaria no sea tan efectiva. Eso.

Ricardo Vilca: Bueno, mi nombre es Ricardo Vilca, presidente de la Comunidad Atacameña de Quitor, San Pedro de Atacama. Sobre lo que estaba hablando Francisca, yo fui una de las personas que al asumir como presidente de la comunidad de Quitor, cuando dijeron administrar nuestro patrimonio, me entusiasmé, me motivé en realizar, con unos dineros que había, un baño y pensé en dar un buen servicio y que el baño tuviera durabilidad en el tiempo. Después que lo hice me sentí desmotivado porque 
dijeron que no tenía la arquitectura, que tapaba el Pukara (de Quitor) y todas estas cosas. Entonces, por una parte el gobierno nos da las herramientas, nos pone los administradores o los servidores públicos del Estado y por otro lado te dicen que eso está malo. Lo íbamos a inaugurar los primeros días de julio, porque en julio y agosto es la temporada alta de turistas extranjeros en San Pedro de Atacama; al Pukara de Quitor llegan al día 370 a 500 personas. Si cobramos $\$ 1.500$ pesos por persona era para pagar al personal, que se iba a ocupar: cinco personas, un administrador, dos guías turísticos, que don Ángel (Bravo) les hizo los cursos, una persona que hace el aseo y un sereno. En lo cual eso quedó en el tiempo, ya han pasado como cuatro meses y quedó botado, el baño como cinco veces he ido a cerrarlo, ya que lo han abierto, porque lo hicimos con duchas, con cerámica, tres lavamanos, tres sanitarios, como corresponde.

Ahora, en este momento Monumentos Nacionales nos pide cambiarlo de lugar o demolerlo, de esos \$5.900.000, $\$ 4.100 .000$ fue del Estado y $\$ 1.800 .000$ de la comunidad. Así por mucho que tengamos el deseo de trabajar juntos, de cambiarlo de lado, pero quién va a poner los dineros, porque todas las cosas se hacen con dinero; entonces uno de repente como dirigente piensa positivo para que tus objetivos sean cumplidos. Nosotros hicimos una propuesta concreta a Monumentos Nacionales de hacer un cierre perimetral para que el baño quedara atrás del cierre, cubrirlo con paja, con piedra o con barro, como se dice en chileno "pintarle la cara al macho", pero espero que lleguemos a un buen acuerdo, que ambas partes pensemos positivo. Monumentos Nacionales protege algo que es de riquísimo valor para la comunidad de San Pedro de Atacama y en especial para la comunidad de Quitor, y que todos los estudios que hagan los arqueólogos deben hacerlos antes. Escuchaba con atención denantes, cuando estaba exponiendo un estudiante, decía que en Arica o en Parinacota pasó algo parecido a Quitor, llegaron, hicieron un proyecto y después de que se estaba haciendo, Monumentos Nacionales dijo que no estaba de acuerdo al lugar. Yo creo que tiene que ser al revés, primero tienen que estudiar los geólogos y todos los que tienen que estudiar y después recién la comunidad realizar sus cosas para no desperdiciar los dineros que al Estado le cuesta mucho también juntar. Eso es lo que quisiera decir a corazón abierto y algo triste es lo que no pude llegar a hacer, pero espero llegarlo. Muchas gracias.

Cristián Catricura: Primero tuvieron que haberse asesorado por las mismas personas que están planteando el proyecto, porque, sólo al verlo, no va con el entorno del Pukara. Entonces plantear algunas posibles soluciones es disfrazarlo entre comillas y ponerle piedras, ponerle paja y que vaya con el entorno del Pukara. O sea, nosotros estamos de acuerdo con esa solución. Pero ante otros posibles impactos que se hagan en el Pukara, o en otro, tienen que haber asesores que planteen algo, tienen que decirles también que hay una ley, que está por sobre la Ley Indígena por ser una ley especial, entonces hay ciertos lineamientos.

Hay un Consejo Local, también se podría haber planteado ahí, antes de haber hecho esta obra de arquitectura, que nos salió bastante cara, y tampoco los recursos del Estado se pueden botar y decir que ya se perdieron esos 6 millones y ahora invirtamos de nuevo. No es eso. Cómo justificamos ante la Contraloría que se botan y se pierden las platas porque está mal construido. Ahora hay que cuidar el entorno, eso está claro, cómo protegemos eso; debiera capacitarse a las comunidades, cierto, y plantearse que cada vez que se vaya a hacer una intervención dentro de un pukara o dentro de algún sitio arqueológico tienen que hacer estos pasos: "estos son los pasos que hay que hacer, punto uno, punto dos, punto tres..." Creo que a lo mejor falta eso, capacitación y educación y luego de eso ir planteando el trabajo en conjunto.
Roxana Seguel (Conservadora, Dirección de Bibliotecas y Museos, Santiago): Estaba escuchando lo que decía don Ricardo, él me mandó un carta justamente a raíz del problema que había tenido con el tema de la implementación que se hizo, yo creo que lo bueno de esta reunión es que por primera vez podemos coordinar aquellas necesidades, inquietudes que tienen las comunidades para recuperar su patrimonio, apropiarse de ello, manejarlo y también tener una participación sobre este patrimonio que está al lado de donde ellos viven. Creo que lo que ha faltado es justamente lo que está pasando en esta reunión, o sea, no hemos tenido la voluntad de coordinarnos ante una idea de proyecto, creo es que lo que más importa, y es por eso que tenemos que coordinarnos muchas personas y mucha gente y eso no es fácil.

Por una parte está la comunidad que esta impulsando proyectos de desarrollo en las comunidades, por otro lado está el Consejo de Monumentos que a través de la ley obliga a velar por ciertas estrategias que tienen que ver dentro del marco legal, por otra parte hay organismos técnicos como el Centro Nacional de Conservación que puede prestar asesoría y el tema es cómo nos reunimos todos para sacar un proyecto de buena forma. Yo creo que todos aquí tenemos una meta común y esa es que el patrimonio no sólo se proteja, sino que también tenga un uso y tenga un buen uso. A mí me llamó harto la atención lo que dijo el dirigente de San Pedro, me pareció súper interesante su intervención sobre el tema de la puesta en valor, de la cual nosotros hablamos. Hay una puesta en valor que tiene que ver con la perspectiva de quienes estamos trabajando en el área y sacando información científica, pero también hay otros términos de cómo poner en valor y eso me llamó la atención de lo que decía el dirigente de San Pedro. Ellos tienen también su propia visión y lo que tenemos que hacer aquí es poner en acuerdo nuestras visiones, porque las visiones no están en absoluto en desacuerdo, sino que son visiones distintas y yo no creo que no podamos trabajar con visiones distintas sobre un mismo objeto y sobre un mismo patrimonio. El tema es que tenemos que sentarnos juntos a hacer un proyecto que sea en conjunto y lo que pasa, porque es lo que le pasó a la comunidad de Quitor con el Pukara, también lo vimos cuando estuvimos hace dos días atrás trabajando y conversando con la comunidad de ChiuChiu, que también tiene un proyecto de la CONADI, que también estaban pensando hacer un trabajo porque tienen los recursos; el tema es cómo hacer mejor ese trabajo y yo creo que el cómo hacer mejor un trabajo se hace a partir de que cada cual aporte el cómo piensa que es mejor y sobre eso llegar a un acuerdo. Yo creo que esta reunión marca un hito en este sentido porque antes siempre se hacía desde un lado y siempre nos encontrábamos que las cosas ya estaban hechas cuando venía el otro lado y decía: "no, en realidad esto se podría haber hecho así, habría quedado mejor", yo creo que en realidad la esencia del trabajo y de los que debiera salir de esta reunión es un compromiso de cada cual, tanto de la gente que trabaja en el ámbito de la investigación como a las comunidades, con la CONADI, como el Consejo de Monumentos que son organismos institucionales, el poder sentarnos juntos en una mesa a conversar cuando se tiene recién la idea de proyecto, no después de que el proyecto esté ejecutado, porque evidentemente cuando ya está ejecutado como decía el colega de CONADI, finalmente perdemos todo, perdemos recursos, perdemos tiempo, perdemos energía, y como decía don Ricardo, finalmente nos vamos desmotivando todos un poco.

Victoria Castro: Está claro que esta es una reunión de comunicación y cada vez que nos podamos juntar hay mejor comunicación que es lo fundamental. Nosotros podemos ofrecer nuestros conocimientos, hacer charlas, conversar, que es mucho más importante que una charla, compartir ideas, en fin, con fechas, con horarios, en los que nos pidan. Pero yo creo que con res- 
pecto a lo que señalaba Roxana, habría que partir, y es una recomendación para la mesa de mañana, que haya una circular muy clara de Monumentos Nacionales, canalizada por la CONADI, pero sin ánimo de ofender a los macrodirigentes, no necesariamente dirigida a los macrodirigentes que la van a conocer, sino a los dirigentes de cada comunidad, como ha señalado Carlos y que se solicite a cada dirigente de la comunidad que sea leída y estudiada en la asamblea comunal, porque los dirigentes también cambian y tiene que quedar inscrito en la maleta del alcalde o en los registros que lleva cada comunidad este tipo de necesidad previa a los proyectos. Digamos que por mucho que nos sentemos a conversar si esta cuestión no queda de algún modo amarrada en un papel, decir qué normas debo seguir, un instructivo, una cosa tan sencilla como eso, independientemente de los asesores, especialistas, profesionales, que cada comunidad sepa que tiene que seguir la ley tanto, y que así pueda plantear un proyecto como decía la Panchita (Greene) con estos antecedentes previos. Yo creo que esa es una recomendación útil para todos que debería quedar ahí y que recoge todo lo que hemos estado haciendo un poco.

Carlos Aguilar: Primero, no compartimos, si he entendido bien, lo que dijo el hermano Galleguillos, en cuanto a la continuación de excavaciones principalmente, no lo compartimos en el sentido de que estoy hablando en nombre de una comunidad, primero eso, y con mucho respeto lo digo. Bueno, creo que cada comunidad o cada pueblo tomará sus decisiones. Quisiera también hacer una pregunta abierta a quienes hacen el trabajo arqueológico y antropológico principalmente, creo que sería importante para nosotros que nos graficaran cuál ha sido el aporte real en dos o tres posiciones distintas dentro de este mundo, el aporte real que se ha hecho al pueblo Likan-Antai desde que ha empezado el trabajo arqueológico, en cuanto a que hay una Sociedad Chilena de Arqueología desde hace cierto tiempo y antes habían sido personas que habían hecho arqueología; entonces desde ese tiempo, quizás antes puede ser, que pudieran graficarnos cuál ha sido el aporte real para el pueblo LikanAntai con dos o tres posiciones distintas, creo que sería importante saberlo aquí cuando hay representantes de esta Sociedad Chilena de Arqueología y también de quienes no pertenecen a la sociedad.

Eso es una cosa, la otra es que, con respecto al turismo sólo quería hacer una observación con respecto a lo que decía Francisca (Greene), y volviendo un poco atrás en la primera intervención que hice, que tiene relación con el turismo, con qué poner en valor o qué revalorizar desde el punto de vista de los pueblos y también sobre estas descoordinaciones que han existido aquí si en esta reunión intentamos trabajar juntos. Bueno, primero que nada estamos aquí en una reflexión sobre el patrimonio cultural, comunidades indígenas y arqueología y creo que pasa mucho por el derecho indígena y cuando tú hablabas sobre el qué hacer... Bueno, quiero dejarlo hasta aquí por ahora.

Donald Jackson: Mire, yo puedo responder parcialmente a su pregunta, en el sentido de que yo no he trabajado en esta zona. Mira la arqueología empezó a través de una agrupación de gente que tenía interés por el pasado, que eran aficionados, aficionados bien intencionados, sin embargo no tenían una formación académica. Hacia los años sesenta, a partir de la escuela de historia de la Universidad de Chile se empieza a formar la Escuela de Arqueología, creo que la formación de esta escuela es un hito importante, ya no son gente simplemente que esté interesada, muy bien intencionada, sino que a partir de esa fecha es gente que tiene una formación en términos teóricos de cómo trabajar, y eso establece una diferencia notable. También se creó la Sociedad Chilena de Arqueología que peleó por una parte para que existiese una Ley de Monumentos Nacionales, que se formuló en el año 1970. También la Sociedad Chilena de Arqueología se preocupó por que hubiese un representante de la sociedad, de los arqueólogos, ante el Consejo de Monumentos Nacionales. María Teresa Planella es nuestro representante ante este organismo.

También como Sociedad Chilena de Arqueología, en el último Congreso celebrado en Arica el año 2000 se sancionó un Código de Ética y ese código está planteando normativas generales dirigidas al comportamiento que deberían tener en el ámbito académico, en el ámbito profesional, los arqueólogos. Se formó también con ese código de ética una Comisión de Ética, de tal manera que si hay arqueólogos que no están cumpliendo con ese código, se les sancione. Yo personalmente he tenido que sancionar arqueólogos porque he visto que no están actuando de acuerdo a las normas básicas. Creo que como seres humanos siempre estamos en la posibilidad de equivocarnos, pero hay veces que uno se da cuenta que hay negligencias y esas las necesitamos corregir; para eso se han creado estos organismos, creo que falta mucho por hacer, falta mucho para generar medidas que no vayan solamente en relación a los arqueólogos o a la comunidad científica, sino también nosotros tenemos que ir incorporando las visiones de ustedes: qué es, en definitiva, lo que les molesta de los arqueólogos; si hay situaciones que ustedes encuentran que no son permisibles, qué hacen los arqueólogos, nosotros las necesitamos saber y a mí como presidente de la Sociedad Chilena de Arqueología les voy a dejar mi dirección, me gustaría que me hicieran saber por escrito qué tipo de situaciones son inadecuadas desde el punto de vista de ustedes y ver de qué manera nosotros podemos ir corrigiendo esas situaciones, la intención de ir mejorando existe.

También creo que hay organismos que velan por este tipo de situaciones, como es el Consejo de Monumentos Nacionales, entonces hay que acudir al consejo y denunciar, si para eso existen las leyes, nosotros tenemos que hacer uso de las leyes. Entonces yo veo que hay un cambio bien importante, creo que de todas maneras la situación no es perfecta, yo creo que hay que ir corrigiendo muchas cosas. Eso es lo que te podría decir en síntesis, veo un cambio bastante grande, pero que todavía se puede seguir mejorando en muchos aspectos.

María Teresa Planella: Lo mío es muy cortito, yo quisiera ampliar un poco más lo del Código de Ética para los arqueólogos profesionales. En el fondo, dentro de ese código que recién se sancionó el año pasado, en el párrafo cuarto del código, que es un párrafo muy importante que tiene que ver con el compromiso de los arqueólogos con la sociedad en general y con las comunidades en particular, ese párrafo tiene siete artículos y de ellos cinco están dirigidos al compromiso de los arqueólogos de solucionar con respecto a las comunidades indígenas. Entonces ha habido una preocupación muy fuerte por parte de nosotros de respetarlos a ustedes, de entenderlos mejor, de una manera mucho más, diría yo, en conocimiento de todo lo que es su patrimonio cultural.

Hans Gundermann (antropólogo, Universidad Católica del Norte): Lo primero que quisiera señalar es que tanto antropólogos como arqueólogos somos responsables, en buena medida, de la construcción de una memoria histórica que se nutre con datos, con conceptos; se nutre con metáforas, se nutre con relaciones, procesos, interpretaciones, presentes en los discursos de los dirigentes atacameños, lo reconozcan ellos o no lo reconozcan. No somos los únicos responsables ni la única fuente de la construcción de los discursos étnicos de hoy, pero sí hemos jugado un papel destacado en ello; recordemos sin ir más lejos que fue Max Uhle quien fue el primero que habló de una posible y también discutible continuidad transhistórica atacameña, cuestión que los arqueólogos básicamente han se- 
guido transmitiendo, han seguido señalando. Max Uhle, a principios de siglo, o sea tenemos casi un siglo de planteamientos de este tipo de relación con los atacameños.

Un segundo aporte que quisiera consignar es el de la identidad. La identidad presupone conciencia de identidad, identidad no es lo mismo que tener una costumbre, o tener un estilo de vida, o un modo de actuar; a ese modo de actuar, a esas costumbres se requiere una conciencia acerca de ello, requiere además una identificación para que esa identificación pueda generar acción, pueda generar organización, acción, propósito, demandas y también discurso, argumentos en torno a este sujeto así identificado. Los antropólogos, y a su modo también los arqueólogos, hemos desde hace más de una década colaborado activamente en esta discusión desde un punto de vista académico, porque eso es lo que nos concierne, para eso estamos preparados, ese es el rol que nos cabe, no suplantar a nadie, ciertamente.

Somos responsables en buena medida, de parte al menos, de que el mundo político de este país haya a finales de la década de los ochenta identificado algo como atacameño, en circunstancias de que era ampliamente desconocido para el mundo político. Somos responsables, en parte al menos, de que este país conozca lo atacameño, en circunstancia de que no existían hace al menos una década atrás canales para hacer esto posible autónomamente; esta situación sin duda hoy día ha cambiado y los atacameños tienen portavoces y dirigentes para realizar esto y hay instituciones a partir de las cuales lo pueden hacer, no obstante, en su momento jugamos un papel importante en esto, hacia el mundo político, hacia la sociedad nacional.

Algo que no se ha mencionado, pero que se mencionó a propósito de lo atacameño, los arqueólogos, Le Paige en particular abrió una ventana al mundo. El turismo, sin duda, es controversial, tiene parte de agraz y de dulce, como se dice, de bueno y de malo, pero como sea, uno de los que efectuaron un aporte fundamental para el conocimiento de lo atacameño no sólo a nivel nacional, sino a nivel mundial, fue Le Paige, lo que explica en parte al menos la afluencia de gente que hoy existe, esto es materia de controversia sin duda, pero ahí está ese hecho.

Por último, yo quisiera también destacar otro aporte de los antropólogos, la capacidad y el interés de romper con los sentidos comunes, de romper con las verdades establecidas, de romper con los mitos; nos anima, a mí me anima por lo menos, como profesional, como investigador, el propósito de conocer más, de no tragarme simplemente el cuento, no tragarme simplemente cualquier argumento, de uno o de otro lado, quiero siempre tener una actitud de escrutinio, de conocimiento, de problematización y eso ha ayudado mucho; esta actitud permanente ha ayudado mucho a efectuar aportes como los que les he señalado. Hay otras cosas más que se podrían consignar, pero obviamente me alargaría en exceso. Gracias.

\section{Presentaciones y opiniones de la tarde}

Donato Gabrieli: La verdad de las cosas este seminario para nosotros, para la comunidad quechua ha sido muy importante, porque, no es cierto, todos los dirigentes de comunidades que llegaron acá, de alguna manera ellos han expresado sobre el proceso de aprendizaje de cómo cuidar su cultura, y en este caso la antropología. Entonces a nosotros nos sirve mucho para aprender, para poder resguardar más nuestros restos arqueológicos, porque de cierta manera, desde el punto de vista turístico nuestra cultura está vista, para nosotros es muy importante que eso se haya visto acá porque nosotros estamos aprendien- do y empezar así con un pie bien puesto en la tierra para proteger nuestra antropología.

Ahora, además yo también quiero decir que aquí, a pesar que como dije recién, que está virgen desde el punto de vista turístico, aquí hubo un saqueo que pese aquí la parte arqueológica nunca se ha visitado en forma masiva por el turista o por el visitante. Fueron años atrás en el sector de Cohasa un comunero de acá se topó con una momia que, de acuerdo a ese tiempo estaba muy bien conservado, entonces de alguna manera llegó a oídos del alcalde de ese entonces y de un curita que estaba acá; entonces el lugareño al principio se resistió a dar la información, pero al final lo convencieron. Así que cuando fueron empezaron a sacar, este caballero, don Jorge Condori de aquí de la comuna, y sacaron tres cajas de esas de plátano que ustedes conocen, con utensilios de la momia, una caja completamente llena de quipus y dicen que había una flecha también y otras cosas; dentro de estas cosas habían chuspas que son unas bolsitas de colores bonitos, incluso a pesar de tanto tiempo, habían maíces, choclitos así en las bolsitas. Entonces para nosotros, si bien es cierto, tenemos en este momento un museo, con el nombre del pionero que es don Leandro Bravo Valdebenito, imagínense ustedes si esa momia, si esa riqueza se hubiera conservado hasta este momento, yo creo que esa hubiera sido una pieza muy importante para nuestro museo. Eso es lo que nosotros sentimos, eso es lo que yo quiero decir a toda la comunidad incluso a los visitantes, que queremos proteger, por eso decía antes que para nosotros es muy importante [...] lo que ustedes dijeron, aprendemos bastante, al menos yo, personalmente, porque desde ese punto de vista nos nace la idea y la fuerza de proteger nuestro patrimonio cultural en el campo arqueológico. Eso no más, gracias.

Sandra Velásquez (profesora, Escuela San Antonio de Padua, Ollagüe): Llevo trabajando cinco años en esta unidad educativa y para mí realmente es una bendición de Dios el poder haber llegado acá como profesora y haberme podido desarrollar en términos profesionales en este tema que es la Educación Intercultural Bilingüe (EIB). La presentación que nosotros hacemos es sobre el trabajo sistemático que ha realizado la escuela a partir del año 1997 hasta la fecha. El tema desarrollado es la EIB en la Escuela San Antonio de Padua de la comuna de Ollagüe.

Para situarnos primero vamos a hablar del contexto geográfico donde está inserta nuestra escuela y nuestra comuna también. Ollagüe es una comuna creada en el año 1980 con un carácter geopolítico. Se ubica a $3.700 \mathrm{msm}$ a 220 kilómetros de la ciudad de Calama y 440 kilómetros de la capital regional Antofagasta. Ollagüe es uno de los tres pasos fronterizos en la región y nosotros estamos conectados por una vía donde pasa el tren internacional Antofagasta-Bolivia. El entorno característico del poblado son los volcanes y salares eternos. En cuanto a sus características climáticas, en términos generales, podemos decir que el clima es adverso por cuanto hay una marcada oscilación térmica que en el invierno estacional va de los $25^{\circ}$ bajo cero como mínima y $\operatorname{los} 15^{\circ} \mathrm{C}$. Presenta dos estaciones invernales, el invierno altiplánico con fuertes lluvias y granizos que van desde el mes de diciembre a marzo prácticamente, y el invierno estacional con bajísimas temperaturas. Las altas cumbres, que sobrepasan los seis mil metros en algunos casos, como el Aucalquincha, presentan nieve durante la mayor parte del año y esporádicamente en nuestra localidad nos vemos afectados por tormentas de arena.

Ahora bien, cómo se ha desarrollado y cómo se ha sustentado la propuesta EIB dentro de nuestra escuela. El contexto sociocultural y patrimonio cultural que presenta la comunidad es difícil por cuanto está la presencia y uso de la lengua vernácula que es la quechua, además hay un montón de tradiciones y cos- 
tumbres que contienen elementos simbólicos y rituales. El uso de la lengua es propio de adultos mayores, cuya variante es el Cuzco-Collao y de características aglutinantes y sufijantes. Esta variante dialectal fue estudiada en el año 1998 por el sociolingüista, don Porfirio Enrique Salas. La actividad más relevante que tienen en el poblado es la fiesta de San Antonio de Padua, ella expresa y contiene el proceso del sincretismo cultural, puesto que este San Antonio de Padua es el patrono del pueblo y muestra la conjunción de dos mundos. Por un lado, el mundo cristiano-occidental y por otro lado la ritualidad del mundo andino. ¿Qué elementos están presentes del mundo cristiano-occidental?: La misa, la procesión, el altar y la celebración de diversos sacramentos; la noche de las almas, el día de la vela, la mesa de once, de mayordomos y alféreces, las lianas, la contabilidad, forman parte de la tradición andina. La fuerte identificación que existe con el folclore hace que diversas manifestaciones aún sigan vigentes. Los bailes no solamente expresan fervor religioso, sino que también están presentes la riqueza del vínculo afectivo que tienen con los elementos simbólicos como la pacha mama el tata Inti y los mallku. Sobre todo en las actividades como el floreo, el carnaval, la siembra y la cosecha. Estas actividades son la expresión más clara de la herencia cultural de esta sociedad de tradición oral.

Cuándo se consolida el quechua en Ollagüe, existen tres etapas históricas que fueron clasificadas en los manuscritos de Leandro Bravo, la etapa de los cazadores-recolectores, la etapa de los pastores del altiplano y la etapa de los mineros de altura, época en que efectivamente se consolida el quechua en Ollagüe, puesto que esa época, que va de la década 1930 a 1950, con la explotación de las minas de azufre, mucha gente del sector de Bolivia cercano a esta frontera viene a trabajar a estas minas y ahí se consolida el uso de las lenguas vernáculas junto a las manifestaciones y las costumbres.

La propuesta de EIB en nuestra escuela hace mención y rescata todo lo que anteriormente hemos visto, y la sistematiza dentro de la unidad educativa. Primero, se sustenta en diversos lineamientos políticos y jurídicos como son la Declaración Universal de los Derechos Humanos, la Constitución Política del Estado, la Ley 19.253 del año 1993 de Pueblos Indígenas, la Ley Orgánica Constitucional de Enseñanza, o LOCE, y el Programa de Educación Intercultural Bilingüe del Ministerio de Educación que nace el año 1996. Los objetivos generales que nosotros tenemos a largo plazo dentro de nuestra escuela son: Primero, legitimar y validar los conocimientos, saberes y valores que tiene la comunidad en la institución que es la escuela; segundo, incorporar paulatinamente el uso de la lengua vernácula como segunda lengua a través de la elaboración de planes y programas de estudio en los diversos niveles educativos, desde primero hasta octavo año básico; fortalecer la identidad cultural a través de la práctica de las diversas manifestaciones culturales.

¿Cómo vamos a llevar a cabo esto? Dentro de los objetivos específicos, para nosotros es sumamente importante incorporar a los agentes culturales, que son las personas de la comunidad, al proceso educativo, por cuanto ellos poseen en propiedad la experiencia y el saber del mundo andino. El segundo, elaborar material didáctico como textos, software, láminas, rompecabezas que van a complementar el trabajo en el aula. El tercero es evaluar el proceso de EIB al interior de la unidad educativa. Evaluar significa hoy día ver si efectivamente todo lo que hemos hecho tiene logros, si ha cumplido con los objetivos y las metas que nos hemos propuesto.

La red de apoyo que ha sustentado nuestro trabajo; son en primer lugar las autoridades locales, desde la administración anterior siendo alcaldesa Patricia Mujica Silva se ha sistematizado un trabajo y siempre el municipio ha estado abierto a apoyarnos en todo lo que la escuela tome como iniciativa dentro de su propuesta educativa. La administración actual también lo hace. La CONADI también nos ha apoyado en el financiamiento de la elaboración de nuestro primer texto. La escuela, con el compromiso de todos los profesionales, sean docentes y paradocentes para efectuar este trabajo. La comunidad con el aporte de los agentes culturales, ya sean como personas de la comunidad, o bien como apoderados. El Ministerio de Educación tanto a nivel central, regional y provincial. Y en los otros, mencionamos el aporte que nos han hecho precisamente quienes están organizando este evento, que son Sergio Avendaño, Patricia Ayala y Ulises Cárdenas, quienes a través de su disciplina nos ayudaron a reorientar nuestro trabajo y a dar un sustento histórico del porqué es necesario profundizar aún más el tema de la EIB.

¿Qué fortalezas tenemos nosotros como unidad educativa? Nosotros funcionamos como un microcentro el que se llama Puka-Sonko, que en quechua significa corazón rojo; desde el año 1997 nuestra unidad educativa, dado el gran espacio físico que tiene, la poca cantidad de alumnos, funciona con jornada escolar completa diurna, esto significa que de las treinta horas que establece el Ministerio de Educación para trabajar semanalmente, nosotros disponemos de ocho horas más de libre disposición para complementarlo con talleres que tengan relación con la cultura. El año 1999, como decía anteriormente, ya funcionábamos como microcentro autónomo porque anteriormente pertenecíamos al microcentro Alto Loa; demás está decirlo que nuestra escuela cuenta con infraestructura adecuada para desarrollar el trabajo. Diversos talleres pretenden orientar el quehacer educativo en áreas científicas, como cultivo de peces y el invernadero. Aquí hay un acuario atrás en unas salas para llevar el conocimiento de los niños no sólo a la valoración de su identidad, sino también para prepararlos para este mundo dinámico, global e insertarlos ahí con esas habilidades y destrezas que este mundo de hoy día requiere. En el área informática, nosotros tenemos una sala de talleres de computación con seis equipos conectados a Internet vía satelital. También el área artística, con el funcionamiento de talleres como folclor, artesanía y teatro, junto con el aspecto valórico que tiene relación con el fortalecimiento de la identidad cultural.

¿Qué hemos hecho en acciones concretas desde el año 1997 hasta ahora? El año 1997 se contextualizan todas las instituciones y escuela, así la Municipalidad tiene su nombre, Carabineros, etc. además ese mismo año la Municipalidad en una iniciativa propia contrata profesionales ecuatorianos de origen quechua para que vengan a capacitarnos. El año 1998 en el verano la comunidad recibe asesoría de parte de profesionales de Bolivia especialmente de Cochabamba, ya que la Universidad Católica del Norte se interesa en trabajar y sistematizar la propuesta de EIB y realiza un diagnóstico de la realidad local. Además se cuenta con la asesoría de profesionales peruanos, como los señores Porfirio Díaz Salas y Dimas Cori, quienes fueron los que definieron la variante lingüística. En 1999 la Universidad Católica del Norte elabora los planes y programas para el nivel básico uno que corresponde a primero y segundo año básico con la asesoría del sociolingüista Porfirio Salas. El año 2000 se publica nuestro primer texto "Esta Es Mi Tierra" que es un texto intercultural bilingüe de características o de orientación medioambiental, esto financiado por el Grupo de Investigaciones Agrarias; el mismo año la CONADI financia la elaboración del libro "Aprendiendo en mi Lengua" que es para complementar la propuesta del Primer Nivel Básico y que abarca cuatro subsectores del aprendizaje. Esto lo hicimos acá en la escuela, participamos todos los docentes en la elaboración de este trabajo. El mismo año la Municipalidad financia la elaboración de un software hipermedial para complementar la propuesta de EIB y para incorporar la informática en el aprendizaje de los alumnos, puesto que ellos interactúan y además es con sonido, lo que favorece la pronunciación, porque recordemos que la lengua quechua es de característica áspera, el uso del 
aparato fonológico difiere radicalmente de cómo nosotros hablamos en español. Este mismo año la Universidad Católica del Norte en convenio con el Ministerio de Educación edita y publica el texto "El Saber de mi Pueblo", que también es para el Primer Nivel Básico.

Las acciones concretas que esperamos lograr de aquí a que termine el año 2001 son: Primero, la aplicación de los planes y programas del Primero Nivel Básico que para el Ministerio de Educación fueron aprobados como planes especiales; elaboración de planes y programas para el Segundo Nivel Básico, ahí trabajaron mucho Patricia, Sergio y Ulises como mencionaba antes, en esta propuesta, porque ahora esta escuela está trabajando directamente con el Ministerio de Educación, ya no hay intermediarios, ya no trabajamos con la Universidad Católica del Norte; otro objetivo es elaborar la continuación del libro, pero para tercer y cuarto año básico, la elaboración de material didáctico, la elaboración de otro software educativo. Finalmente nuestra propuesta, que como proceso educativo interminable es perfectible, quiere ir construyendo desde las realidades locales, lealtades crecientes e identidades conscientes con el fin de internalizar el principio de la diversidad, valorizando lo propio para así valorar los otros mundos. $\mathrm{Mu}-$ chas gracias.

Victoria Castro: En primer lugar un agradecimiento a la comunidad runasimi quechuaparlante de Ollagüe que gentilmente nos ha acogido. También quisiera especialmente agradecer a quien inspiró de alguna manera esta orientación que hoy día comparte toda la comunidad, nuestro colega Leandro Bravo y además a su señora que impulsó detrás este proyecto que continúa todavía; por último agradecer a los organizadores del evento y el apoyo por supuesto de CONADI, y si alguien por favor olvido me disculpan. La verdad es que hace poco más de treinta años somos nosotros parte de la prehistoria, con mi compañero acá presente Carlos Aldunate y muchos estudiantes que hoy día son colegas iniciamos nuestros estudios principalmente de las comunidades del Loa Superior, en la subregión del Río Salado. Quizás con una forma un poco distinta de hacer arqueología, porque nuestras profesiones de origen, un leguleyo como mi compañero Carlos y una profesora de filosofía primero antes de ser arqueóloga como soy yo, nos dio una mirada que tal vez la arqueología en esta zona había que estudiarla de manera diferente y por eso nosotros hicimos muchos proyectos de investigación bajo una orientación que la arqueología llama la etnoarqueología, pero que en realidad es nada más que el antiguo y viejo método histórico-comparativo que inspira al arqueólogo en el conocimiento que ofrecen los herederos de la tradición cultural prehispánica, para orientar hipótesis sobre los restos arqueológicos que encuentra.

Pero como les decía, en este interés un poco más amplio de la arqueología, nosotros también nos dimos cuenta que nuestros colegas, los antropólogos sociales, con excepciones, trabajaban en forma mayor ciertos problemas de parentesco que no los podemos ver en los objetos materiales, en problemas de la sociedad contemporánea y que habían saberes, conocimientos necesarios para entender mejor el pasado, que provenían de cómo la gente bota su basura, de cómo la gente hace su techo, de cómo la gente construye sus adobes, de cómo la gente talla su piedra, etcétera, la lista es larga. Así fueron nuestros trabajos, nosotros adquirimos casi un compromiso más allá de ir a una comunidad como pedir los permisos, explicar lo que hacíamos, de amistad con una comunidad en especial porque pasamos muchos años de la vida estudiando ahí y participando con las personas en sus trabajos, en sus ceremonias también, esto con la comunidad de Toconce. Por eso que tanto la "Asociación Indígena Atacameña Puri Linzor" de los jóvenes como la "Asociación de Costumbres y Tradiciones del Loa" ha recibido un conjunto de las publicaciones de los resultados de nuestros es- tudios, cuestión que también han hecho otros colegas como el caso de Mauricio Uribe. Me gustaría sin embargo, muy brevemente, puesto que hemos hecho muchos trabajos, mostrar un ejemplito de un proyecto que fue un poco más amplio, más allá de las comunidades del Loa Superior.

Entre medio les cuento que, y un poco contestando a Carlos [Aguilar], un poquito no más porque queda mucho más que conversar sobre eso. Una experiencia concreta fue elaborar un libro sobre la limpia de acequias en Toconce y Ayquina hace unos años, en donde participamos como ayudantes de cocina las mujeres y los hombres como peones. Bueno, conseguir los fondos no fue fácil, porque la imprenta es cara cuando un libro es a color, hicimos un libro descriptivo porque pensamos que uno de los temas complicados de la memoria histórica es que si se fija en un escrito lleva como un ejemplo de cómo las cosas eran en este momento y puede ser ampliado, modificado, etcétera, pero las imágenes visuales ayudan mucho también a ver lo que se usaba, el vestuario que se usaba, los instrumentos musicales, la forma de organizar el espacio, etcétera. Ese libro se entregó en asamblea comunal a cada comunero de estas dos comunidades y se aclaró a través de una carta escrita que el pago a la persona que diseñó el libro, puesto que no había plata de por medio, se hacía entregándole a esa persona cincuenta libros para la venta que en realidad vendió a menos del precio de costo porque no estaba en ese espectro de cosas y el resto fue de donación. Es un libro del que tengo un ejemplar para dejar a la comunidad de Ollagüe, a la presidenta y que de todas maneras aquellas comunidades que no lo tienen se les puede enviar.

Ese es un aporte concreto que la gente de los pueblos valoró porque es su libro, o sea es de ellos y esta hecho un poco para que quede dentro de las posibilidades que tienen de organizar espacios con textos escritos. Este proyecto más amplio se llamó Ciencia Indígena en los Andes de Sudamérica, etnobotánica de las tierras altas del norte grande de Chile y tomó, hace muchos años con Carlos también, pero con unos botánicos hicimos un trabajo en la comunidad de Toconce en donde nos pareció importante comparar el conocimiento que la ciencia universitaria tiene de la flora silvestre de la zona y el conocimiento que tienen los pueblos indígenas específicos de su flora, de todo lo que existe, de la rica-rica, del pingo-pingo, etcétera, tantas otras plantas y ver cómo cada ciencia organizaba este conocimiento.

La idea de este trabajo fue que al terminarlo, con ciertas dificultades que son largas en el tiempo por problemas de financiamiento, era bueno producir por un lado escritos muy científicos y otros escritos con láminas y muy serios, con los dos aportes de conocimiento para que cada comunidad donde se hizo el estudio tuviera un libro con un ejemplar de este material y pudiera plantearlo para sus proyectos o para lo que quieran hacer, además de un libro que lo acompaña donde hay una identificación de la palabra como es nombrada la planta y su significado en las lenguas de los Andes del sur que, aparte de aquellas lenguas que en el siglo diecinueve se llaman kunza para la región atacameña, existe la lengua quechua, la lengua aymara, la lengua puquina, varias lenguas que se mezclaron, para ver en cuántas de estas lenguas tenían su significado.

Todo esto pensamos que puede ser útil a futuro, este libro está hecho en maqueta todavía, hay que buscarle financiamiento, pero creemos que es otra forma de aportar. Ahora, ese libro tomó comunidades mucho más allá del Loa Superior, algunas de aquí también como es el caso de la comunidad de Caspana, otra comunidad más de acá entre los dos mundos del Salar de Atacama y del Loa Superior, como es el caso de la comunidad de Río Grande y toda una serie de comunidades del altiplano de la primera región y creemos que con eso, un estudio previo, hecho en el año 1981, por parte de las mismas botánicas pero con otra colega antropóloga en la primera región, quedó orde- 
nado de alguna manera en el escrito. La cosa escrita tiene virtudes aunque también tenga defectos. Toda la información sobre la flora natural, toda la flora no sólo de las plantas medicinales, no sólo las alimenticias, no sólo las forrajeras, no sólo las coas, perdón las plantas sagradas, en fin, quedó lista para ser utilizada por las comunidades en términos de que también hay una forma de ver la naturaleza, que sencillamente muestra dos formas de conocimiento y de organización en donde la parte indígena tiene una parte que involucra más la ciencia que la taxonomía o la forma de clasificar de la ciencia universitaria, porque incorpora la dimensión, como debe ser además de la forma de ver el mundo de lo que se considera lo sagrado. Creemos que estas han sido experiencias que pueden aportar a través del tiempo y yo creo que estoy en el tiempo, así es que muchísimas gracias.

Carole Sinclaire (arqueóloga, Museo Chileno de Arte Precolombino): Quiero reiterar el agradecimiento por haberme invitado a participar de esta reunión; para mí es muy importante poder estar aquí y poder verle los rostros a todas las personas que de alguna manera están involucradas ya sea en el trabajo científico o aquellos representantes de las comunidades que habitan este enorme territorio. Creo que, como bien decía Carlos [Aldunate] esta reunión va a tener un efecto multiplicador y espero que puedan seguir haciéndose muchas más de manera de poder ir desarrollando cada vez un diálogo mejor entre nosotros como científicos y las comunidades indígenas.

Me presento, yo soy arqueóloga, vivo en Santiago, pero llevo más de veinte años viniendo a esta zona y parte de mis gestores y maestros están aquí presentes y a ellos les debo el que yo esté aquí y que esté desarrollando mi trabajo, mi profesión, de la manera en que lo hago y con el gusto que lo hago también. Voy hablar a título personal, pero también voy a hablar en nombre del equipo de trabajo que yo conformo, vengo un poco en representación también de ese equipo, que también es un equipo de profesionales que derivó de este primer equipo que formó Carlos y Vicky [Castro] y José Berenguer trabajando en la zona, en el área de Toconce y somos un poco la generación que siguió a la de Mauricio Uribe, o sea, entremedio de Mauricio Uribe y de la Leonor Adán estábamos nosotros; ellos son como la tercera generación, nosotros somos como la segunda generación. Uno podría hacer una historia muy interesante de lo que es la formación del arqueólogo siguiendo este tipo de ideas.

Voy a leer un par de párrafos y como les decía es algo bastante personal, de hecho está escrito, en primera persona, me comprometo mucho con lo que estoy diciendo y creo que lo más importante que yo estoy hablando acá, es más que como arqueóloga como ser humano, como persona que desarrolla un trabajo y una profesión aquí, que es parte esencial.

Primero que nada, he llegado aquí como representante de un equipo de personas que hemos hecho de nuestra estadía acá en esta región una manera de vivir y de concebir la vida. Un aporte esencial de ella es nuestro trabajo, la profesión que ejercemos como arqueólogos y elegimos hace mucho tiempo atrás, que queríamos desarrollarla en este lugar del país, pudiendo haber elegido cualquier lugar o región. Cuando nos abríamos al mundo profesional nos invitaron a participar justamente acá en la cuenca del Río Salado, ya no estamos en la cuenca del Salado, sino que estamos bastante más arriba, donde yo y varios de mis colegas dimos nuestros primeros pasos en nuestra profesión buscando las huellas del pasado del hombre. Han pasado más de veinte años y todavía sigo en este lugar, viniendo una vez al año o cada vez que nuestros recursos lo permiten, recursos que entrega el Estado o los centros universitarios para desarrollar proyectos de investigación.

Si me preguntan por qué venimos a este lugar tan lejano, lejos de donde solemos vivir, les contesto con el corazón, por- que amamos este lugar y porque nos sentimos parte de él, aunque la población que aquí habita pueda pensar diferente. Para mí este lugar, marcado por una geografía hermosa, cambiante, a veces demasiado amplia, con sus planicies, grandes alturas y profundas quebradas, que para mi persona que viene de un valle estrecho, contaminado que es la capital de este país, aquí descanso y me cargo de energías para seguir existiendo. Como bien dijo una amiga de Turi alguna vez: "ustedes vienen para acá porque allá no les gusta vivir", y eso es muy cierto, cuando venimos a trabajar, entre comillas, en arqueología en estos lugares, venimos buscando vivir un poquito acá, venir significa un gran esfuerzo, pero lo hacemos con gusto. Tanto es el tiempo que estamos viniendo que hemos visto convertirse en adultos a los niños que alguna vez nos acompañaron en nuestras incursiones y estudios por este vasto territorio.

Mi experiencia me dice que desde siempre hemos sido bien acogidos por la gente que vive acá. Estando en Toconce por años y en estos últimos diez años habitando en la casa comunal de la comunidad de Turi cada vez que venimos a trabajar, nunca se nos cuestionó nuestro trabajo, si se nos preguntaba qué veníamos a hacer desde tan lejos, nosotros contestábamos a conocer como vivían las gentes de estos lugares en el pasado, a conocer y estudiar sus testimonios, porque estamos ávidos siempre de conocer, es parte de nuestra condición como seres humanos. Una labor que en particular hice con mucho respeto por las personas que aún viven en estos lugares, siempre de cara a ellos, nunca escondiendo lo que hacíamos, porque no pretendíamos sacar provecho ni beneficio alguno con nuestra actividad.

Al trabajar en arqueología en esta región no busco el hallazgo que me haga famosa profesionalmente ni tampoco un provecho económico, porque esta actividad lo que menos produce es dinero. Trabajo en arqueología porque es mi principal actividad como ser humano, me permite conocer cómo vivimos en el pasado, investigando e ideando las maneras y métodos para descubrir todo aquello que el hombre antiguo no dejó por escrito en estos lugares, sino en los restos de sus viviendas, en los dibujos y pinturas de las paredes de las quebradas, en sus basuras y monumentos arquitectónicos. Para relevar estos testimonios y comprenderlos, la arqueología tiene muchos y variados métodos, como el registro, el dibujo, las excavaciones, el estudio de los objetos que hacían, la cultura material, el análisis de sus restos de comida. Métodos científicos para fechar estos acontecimientos del pasado y ordenarlos en el tiempo. En estos últimos diez años, hemos venido realizando con mi equipo de trabajo diferentes estudios concentrados en una de las expresiones humanas más nobles, como es el arte rupestre, que se encuentra instalado y disperso en las múltiples quebradas de este vasto territorio. Siempre nos llamó la atención la gran cantidad de lugares que presentaban este tipo de manifestaciones y luego de varios años de estar estudiándolos hemos llegado a la conclusión que este lugar tiene un arte rupestre que es único y propio de acá.

Jerónimo Anza: Soy presidente de la Comunidad Atacameña de Caspana. En primer lugar me siento contento de las personas que me invitaron a mí a esta reunión. Ollagüe no lo conocía y eso que estamos tan cerca, me siento feliz en este minuto de estar con Donato Gabrieli, a él si lo conocía. Bueno, nosotros como caspaneños lo único que tenemos es un poco de avance en un proyecto en la parte del turismo y ahora estamos proyectando un albergue turístico en Caspana, el problema es que no podemos obtener el título de ese terreno, lo único que más adelante quisiéramos nosotros tener, así como lo tienen Río Grande, son los derechos territoriales, por qué, porque siempre todos los pueblos que como nosotros no tienen los derechos territoriales no se respetan, no hay respeto, entonces la gente, no todos, vienen y nos tratan como si no existiéramos en nuestro pueblo. 
Ustedes ven que los pueblos están estudiados y recontra estudiados, pero es repoco lo que queda para los pueblos como este caso para la parte turística. Por ejemplo ahí el museo que tenemos ahora en Caspana toda la plata que llega va a parar a Calama, a la Corporación de Cultura y Turismo. La CONADI nos ha apoyado, no nos ha discriminado, INDAP y la Gobernación también nos ha apoyado bastante en los últimos tiempos.

También yo quería mostrar un video de otra obra que se quería crear en Caspana, y eso a nosotros no nos conviene como caspaneños. Porque primero se hacen las cosas y después nosotros somos los últimos en saber, los de los pueblos, eso es verdad, en el video nosotros mostramos que hay muchas partes ceremoniales. En este caso nosotros celebramos en grande la limpia de canales, entonces ahí estaría quedando dentro del parque y eso no puede ser, pero eso después se los voy a mostrar en el video, cuando tengamos un lugar. Y eso no más sería, muchas gracias.

Wilson Galleguillos: [Hace un saludo en su lengua originaria]. Buenas tardes hermanas y hermanos, soy un hombre del desierto de Chiu-Chiu, de la comunidad de Chiu-Chiu. Bueno, en realidad mis hermanos y dirigentes de otras comunidades, hay muchas cosas que tienen relación, en parte, con la misma temática, yo he propuesto una alternativa económica para Chiu-Chiu, generalmente porque es un turismo indígena comunitario, en la cual yo veo ventajas y desventajas.

Las ventajas son, primero, absorción de mano de obra local, como también el regreso de familias que antes habían emigrado, están retornando a nuestro pueblo porque la situación en Calama no está muy bien económicamente. En segundo lugar, tenemos inversión por parte del Estado, así es que la CONADI y otros organismos públicos como el INDAP están invirtiendo dineros estatales para la construcción de albergues y restauración de sitios arqueológicos, como es el caso del Pukara y el Museo. En tercer lugar, tenemos el reconocimiento legal, cosa que antes no estaba contemplada, entre comillas se puede decir que es una concesión momentánea durante cinco años, esto tiene ciertos parámetros de regla, es decir si la comunidad no invierte durante ese período de cinco años prácticamente el Ministerio de Bienes Nacionales se reserva el derecho de retirar esa concesión. Cuarto, creo que el turismo puede crear sensibilidad en la gente que nos visite, en cuanto a proteger el medio ambiente, la flora y la fauna originaria.

También otro punto importante es el fortalecimiento de la identidad porque el turista, he observado últimamente, es gente que viene preparada, sabe mucho más que los atacameños, inclusive, en la parte cultural, viene muy informado. Por lo tanto eso también nos da lugar a que nosotros comencemos la artesanía tradicional típica del lugar, el patrimonio arquitectónico, el patrimonio paisajístico inclusive. El pueblo va tener que sufrir cambios para el bien de los turistas, como también para recuperar nuestra identidad.

Esos más o menos son a grandes rasgos las ventajas, pero sabemos que como no puede existir el bien sin el mal también existen desventajas, como es el caso de que se nos pueden aproximar grandes consorcios turísticos, como empresas que manejan mucho capital que para ellos es fácil instalarse en el lugar, de esa manera nosotros pasaríamos a un segundo plano, eso yo lo veo que es muy peligroso. Lo otro también es el aspecto social, ahí prácticamente ingresa, se quiera o no se quiera reconocer, el alcohol, la droga y la prostitución, eso yo creo que también hay que considerarlo.

El impacto ambiental es también muchas veces terrible porque muchos turistas no tienen conciencia ecológica, suben de repente a hacer ceremonias en lugares que son sagrados y llevan pura chatarra y ni siquiera llevan cosas orgánicas, dejan basura, eso me parece que es una falta de respeto muy grande. En cuanto a Monumentos Nacionales, vemos por una parte de que tiene las intenciones, pero por otro lado también nos pone muchas trabas burocráticas; es así que se aprobó un proyecto en Chiu-Chiu para el cierre perimetral, sin embargo tiene que pasar todo por el consentimiento de Monumentos Nacionales, muchas veces, nuestros ancestros los grandes maestros en piedra son arquitectos tradicionales por decirlo de alguna manera, ellos conocen la piedra mejor que nadie, saben trabajar la piedra, la greda, el barro, ellos saben, aquí no es preciso tener un conocimiento científico-técnico para hacer una pared, entonces ahí veo que hay un poco de trabas.

Lo otro también, en que concuerdo plenamente con el hermano de Caspana, es que se efectúan, o se están efectuando algunos proyectos o se van a llevar a cabo algunos proyectos a futuro, en consecuencia que las comunidades están dialogando con el Ministerio de Bienes Nacionales para delimitar los límites comunitarios. Así es que tienen que tener mucho cuidado en qué comunidad van a penetrar, particularmente Chiu-Chiu es una comunidad que va a tener mucha atención con la gente que va a ingresar al sector. Esto porque hemos visto que se han hecho muchos estudios que han dejado la cosa al libre albedrío, han dejado así al aire, no han comunicado los resultados oficiales, no sabemos de qué años son, por qué los hicieron, con qué recursos, para qué fin; entonces muchas veces se hacen las cosas y después quedan en el aire, la comunidad en definitiva queda sin información. Y lo otro que es más preocupante es la parte ambiental, quiero tocar un tema que va a salir pronto al tapete, como es el caso de la minera San Cristóbal, la que pretende transportar 62 camiones diarios, cada uno con 30 toneladas, pasando por los sitios sagrados como son los cementerios indígenas que existen en Chiu-Chiu; más aún hace pocos meses descubrimos una aldea que para mí tengo entendido que probablemente sea más antigua que Tulor, muy cerca de Chiu-Chiu, entonces yo creo que aquí hay una tarea no sólo para la comunidad, sino que para el mundo científico como son ustedes cierto, los sociólogos, antropólogos, arqueólogos, por nombrar algunos.

Así es que yo les invito a reflexionar en este tema, porque no es posible que la economía que se aplica hoy en día, que es injusta, inhumana y depredadora, acabe con nuestros hermanos, con nuestro pueblo, con nuestra cultura, que nosotros no estamos de ayer, son más de doce mil años de historia, por lo tanto la historia es historia y pesa en el tiempo, y yo les invito a ustedes a reflexionar, porque nosotros hicimos las observaciones pertinentes, dentro de los plazos legales, a este estudio de impacto ambiental felizmente a tiempo; ahora está paralizado y ahí precisamente nosotros la única manera para desviar esa ruta es con un estudio arqueológico que demuestre con casos concretos la veracidad de que allí sí existe un cementerio, de hecho existe, yo no sé cómo se les pasó esto a CONAMA cuando hizo el estudio la Minera El Abra. A mí me da mucha pena porque estoy seguro, no voy a nombrar la persona, pero habían arqueólogos que tenían conocimiento que allí existían cementerios indígenas y sin embargo no levantaron la voz, menos Monumentos Nacionales; entonces ahora yo pienso que tiene una deuda muy grande con nosotros y ahí debieran restituir y desviar definitivamente a través de un bypass que nosotros propusimos en su oportunidad, antes de llegar a Lasana retomar un camino antiguo que empalma con el camino de la cañería para llegar a Calama y ahí no estaría afectando lo que es el cementerio indígena; le propusimos también a la empresa que por qué no utilizaba el ferrocarril, es mucho más fácil, y más económico quizás, pero yo veo aquí que el estudio que se hizo lo hizo una empresa favoreciendo a la empresa San Cristóbal. Porque sabemos bien que la Ley de Impacto Ambiental generalmente faculta a una empresa particular, o a una ONG, que haga el estudio y hacen los estudios, los libracos, cosa que para la gente que tiene CONAMA se le hace insuficiente ni para hacer la revisión correspondiente; qué pasa, se cumplen los plazos y ellos optan por lo más fácil que es aprobar el proyecto, así de simple. 
Yo creo que aquí ustedes, el mundo científico, son los llamados a reflexionar y hacer un pare a esta situación, esto no puede existir, genera mucha pena, mucha pena y ojalá nunca más ocurra como en San Pedro de Atacama que se construyó un hotel arriba de un cementerio con el visto bueno de un arqueólogo, que según él tiene mucho prestigio, no lo voy a nombrar pero ustedes saben quién es. Entonces me da mucha pena, yo llamo al señor de la Sociedad Arqueológica para que tome cartas en el asunto y esa persona que dio el visto bueno allá en San Pedro de Atacama, con un compromiso ético, no sé, hacerle un llamado, porque lo que pasa es una cosa muy grave. Construir sobre vidas humanas yo creo que es ya un delito terrible. En Chiu-Chiu nosotros no vamos aceptar ese tipo de cosas, nosotros estamos dispuestos a permanecer, pero con un turismo con identidad, como una segunda alternativa económica, sin abandonar nuestra agricultura, nuestras tierras, porque las tierras van a permanecer por siempre y el turismo es sólo un fenómeno pasajero, nosotros estamos claros que el turismo no es eterno, la tierra es eterna como lo es todo lo que brinda la naturaleza, así es que por lo tanto, yo le doy las gracias muy particularmente a las personas que invitaron a la comunidad de Chiu-Chiu como también a los anfitriones como es la Comunidad Quechua de Ollagüe; insisto, les invito a que nunca más seamos intrusos de nuestra propia tierra. Por último, quiero finalizar diciendo que la continuidad de la humanidad está precisamente en la sabiduría de los pueblos indígenas. Muchas gracias.

Cristián Pérez (Comunidad Atacameña de Lasana): [Hace un saludo en su lengua nativa] Saludos a todos los hermanos y hermanas. Bueno, que les puedo decir, Lasana es un valle de aproximadamente diez kilómetros de largo, tenemos ahí el gran "Pukara" de Lasana, Monumento Nacional. Tenemos como todos los pueblos carnavales y nuestras fiestas patronales.

Quisiera hacer un comentario ahora, ahora que tenemos la oportunidad de estar con ustedes, al mundo arqueológicoantropológico de lo que se ha hecho en la zona, donde se han estudiado tres cementerios indígenas, actualmente saqueados, no se si por personas con fines de lucro o por arqueólogos, o no sé qué, lo cierto es que estamos tratando de recuperar Lasana que sufrió una gran destrucción, y ahora ya estamos recuperando eso, estamos recuperando nuestro patrimonio, lo que no hicimos antes lo estamos haciendo ahora. Y quisiéramos hacer hincapié los hermanos de Lasana que toda la información que sacan de nuestros antepasados que vuelva al pueblo, es algo que toman de nosotros y lo tienen que devolver. Eso es lo que ha sucedido y me gustaría que ahora se formen los canales de comunicación para que toda esa información que ustedes traen vuelva al pueblo. Ahora Ricardo les va a exponer sobre el gran proyecto de puesta en valor del Pukara de Lasana. Gracias.

Ricardo Bautista (Comunidad Atacameña de Lasana): Bueno, yo les voy a hablar del proyecto del Pukará de Lasana. Hay un arqueólogo que ha estado en el Museo, que nosotros estamos recuperando, que se llevó varias cosas de nuestros locales. Estamos haciendo los baños.

Gran parte de nosotros esto lo hicimos pero para fomentar el trabajo, sin dejar de lado la agricultura, un poco de trabajo para que la gente, los jóvenes que visiten a Atacama, para que vayan al Pukará y los podamos atender.

Cristián Pérez: Quisiera darles gracias a los organizadores, la comunidad de Ollagüe, a los hermanos que vinieron. Es bonito Ollagüe, harto frío. Bueno eso sería todo. Muchas gracias.
Hans Gundermann: [Primero lee carta enviada por el director del Instituto de Investigaciones Arqueológicas del Museo de San Pedro de Atacama, a los organizadores del encuentro]. Cuando me propuse participar en esta reunión pensé hablar brevemente acerca de cultura y globalización, es decir, qué tipo de fenómenos, qué cosas pasan cuando las culturas, comunidades étnicas se encuentran en una situación de apertura drástica, de una apertura profunda, de una dinámica de un conjunto de presiones, de un conjunto de mensajes, signos de ideas, etc., muy profusas. No obstante me parece de mayor interés hablar para ustedes acerca del tema de cultura andina y cultura-patrimonio, ex profeso no hablo de patrimonio cultural, sino que quisiera presentar algunas ideas acerca de lo que pudiéramos denominar cultura-patrimonio.

En mi oficio me han enseñado que cualquier conversación razonablemente consistente empieza por las definiciones de conceptos, de qué estamos hablando, y quiero un poco hacer profesión de ello en este momento y tratar entonces no la idea de patrimonio cultural como algo dado, sino que más bien problematizar la idea de patrimonio cultural a través de la noción de cultura-patrimonio. El concepto de cultura es un concepto que define a los antropólogos, pero es también bastante escurridizo. Quiero proponer tres acepciones al concepto de cultura, tres acepciones relacionadas.

El significado más general del concepto de cultura sería el de estilo de vida, modo de vida, patrones de comportamiento, sistema mental, etc. Esto tiene una expresión materializada, una expresión objetiva, en cosas, en objetos, en patrones de conducta, en modos de comportamiento, pero también en cuestiones subjetivas o mentales, es decir, en esquemas mentales, en representaciones, en disposiciones a actuar, en valores, valoraciones e identificaciones, formas de apreciación, juicios, opiniones, etc. En relación con esto, si esto en su sentido más amplio es cultura, modo de vida, estilo de vida, formas de comportamiento que son características de los grupos sociales, en donde normalmente es bien difícil ver los límites, donde termina algo y donde empieza otra cosa, pero, salvando ese asunto cabe preguntarse, entonces, si esto es cultura; de qué cultura andina, atacameña, aymara o colla, de reciente aparición, estamos hablando.

Hay dos constataciones que me parece que son ineludibles cuando uno habla de cultura en el mundo andino del norte de Chile. La primera constatación es que estos estilos de vida, estos modos o manera de comportamiento han estado sometidos, sobre todo en los últimos dos siglos, pero en especial durante los últimos cincuenta a sesenta años, a procesos de modernización, que tienen que ver con el tema de la educación, que tienen que ver con los mercados de trabajo, que tienen que ver con el aumento de las comunicaciones, la urbanización, las migraciones, el aprendizaje del castellano en el caso aymara, toda una serie de fenómenos que genéricamente se les llama procesos de modernización. Lo que la cultura andina es hoy, bajo esta definición, es una cultura modernizada o sujeta a procesos de modernización. Muchos de estos patrones o esquemas mentales dependen o tributan de estos procesos sociales que acabo de esbozar.

Una imagen posible para visualizar esto es la idea de que en la cultura en los sujetos en la sociedad andina, existen varios ámbitos o planos culturales, lo que le da a la cultura, en realidad, gran complejidad. Las culturas tradicionales -eso es si es que acaso fueron alguna vez relativamente simples, integradas y sencillas- hoy en día bajo estas condiciones de modernización, las culturas andinas son complejas, heterogéneas, contradictorias, con muchas tensiones internas. ¿A qué tipo de plano me refiero con esto? Sin duda hay una veta o un aspecto tradicional que tiene que ver con la continuidad de ciertos esquemas de pensamiento, la continuidad de ciertos modos de actuar, la continuidad de una serie de costumbres, de ritos, etc., pero hay también muchos otros. 
La cultura atacameña, por ejemplo, es una cultura hoy que tiene mucho que ver en un plano político con las tradiciones sindicales originadas -o que han incorporado en una relación más que centenaria- con el mundo minero y con el despertar político del mundo minero en el norte de Chile, de lo cual ellos no han sido ajenos. Los atacameños son también, por citar otro ejemplo, activos consumidores y gustan mucho de músicas muy actuales, por ejemplo la música chicha o cumbia andina, que dependen como hechos culturales del ámbito atacameño, dependen más bien de un ámbito subregional andino de amplia extensión, retroalimentado ahora último por una activa presencia argentina en esto de la música chicha. La música predilecta del mundo atacameño hoy en día es lejos el sound, pero no es tradicional, es algo que se origina, se expande como industria cultural, ya no es la música de una localidad donde algunas personas la sabían, la mantenían y la enseñaban a otros. Hoy en día es una música que se ha incorporado y que es sentida como propia y de la cual se gusta mucho, pero que esa difusión y esa producción dependen de industrias culturales. Bueno todo el mundo toma ya Coca-Cola, estamos sometidos al imperio de las transnacionales, etc., es decir, doy ejemplos sencillos de una cuestión que en realidad es mucho más compleja y es que la cultura andina -y la cultura mapuche también- son culturas más complejas, mucho más heterogéneas, mucho más tensionadas internamente de lo que estamos dispuestos a reconocer. Esa es una de las implicaciones de ver de un concepto de cultura que es puesto en perspectiva histórica, no podemos obviar el hecho de esta multiplicidad, heterogeneidad y complejidad. No me pronuncio si es bueno o si es malo, me pronuncio por lo que un conjunto de evidencias aportan en este sentido, no obstante hay otra manera todavía en que es posible considerar la idea, la noción o el concepto de cultura.

Cultura uno también la puede entender como aquello que la gente declara que es cultura, es decir, como un comportamiento declarativo, lo que la gente dice que es cultura: "cultura es esto". En las poblaciones andinas el surgimiento de este concepto es una cuestión reciente, es cosa de una década, quizá un poquito más en que empieza a concebirse la idea de cultura. Hay algunos conceptos que son más vernáculos, son propios de la gente que pudiera asociarse a esta cuestión, la gente aymara hablaba de "la costumbre", los mapuches hablan del admapu, hay también conceptos propios que señalan, pero esos conceptos vernáculos alimentan, más bien se incorporan a esta noción nueva.

Esta noción nueva, entonces, es posible cuando se plantea una reflexión, cuando hay agentes, cuando hay gente ahí, andina o no andina, que plantea el tema de la cultura y esto es elaborado o es incorporado por los miembros de una población étnicamente definida. Esta idea de cultura es clave, es una premisa, es un supuesto, sin eso no es posible hablar de grupo étnico si no hay una identificación de algo como cultura que además pueda ser retroalimentado por nociones como admapu, o nociones como la costumbre, en el caso aymara, no es posible pensar la identidad étnica, la etnicidad y fundar un principio de identificación étnica, se necesita entonces un concepto de cultura como el que acabo de señalar, pero este concepto de cultura es nuevo, tiene sus antecedentes pero es algo básicamente nuevo de los últimos diez a quince años.

En tercer lugar propongo un concepto de cultura ya con un adjetivo, cultura patrimonial, cultura patrimonial a un cierto número de comportamientos, de símbolos, de objetos a los que se les otorga un valor especial, en términos más específicos cultura patrimonial es aquello que se define como patrimonio. El discurso del patrimonio, el argumento de lo patrimonial tampoco es algo andino, tiene básicamente tres fuentes. La primera es el Estado, la CONADI y el Consejo de Monumentos Nacionales son organismo que tienen como un elemento central la idea y la noción de patrimonio y por lo tanto de cultura patri- monial. Pero también se origina en ciertos agentes como los arqueólogos. Los arqueólogos son especialistas en generar conocimiento, pero de una manera acrítica. Por lo general asumen, sin una reflexión mayor, que lo que ellos generan, los objetos que ellos levantan o el conocimiento que ellos generan son automáticamente patrimonio. Este paso es un paso desde mi punto de vista problemático, no es automático y no es normalmente objeto de reflexión.

Por otra parte, sin duda, la idea de patrimonio encuentra también eco en acepciones que parecen estar presentes en algunas culturas indígenas, como ciertos sitios sagrados asociados a lo religioso, que son considerados formando parte de aquello que se concibe como el admapu, pero que además ocupan una posición central, puede ser pensado quizás como el corazón del аdтари. Versiones con mayor o menor fuerza también existen en el mundo andino y tienen que ver precisamente con el tema de lo religioso.

Ahora, esta idea de cultura patrimonial o patrimonio así constituida es nueva, también es una cuestión de la que se empieza a hablar. Se empieza a reflexionar, se empieza a definir en el ámbito atacameño o aymara, se empieza a hablar muy reciente, quizás sólo en los últimos años a partir en buena medida de la actividad de la CONADI; es un tema que empieza ahí a plantearse y ahí empieza a definirse lo que es patrimonio. El tipo de cosas que les estoy señalando apuntan a lo siguiente, intento mostrarles cosas que para ustedes son obvias de una manera no obvia. Es decir, intento mostrarles que mucho de aquello con lo que trabajamos son construcciones sociales, son elaboraciones sociales que tienen complejos procesos de constitución y que normalmente les damos una condición esencial, les damos una condición antigua, los planteamos como algo dado, como algo que no necesita ser reflexionado, como algo que no necesita ser cuestionado.

Están atribuidos a los procesos de etnogénesis o etnificación de la última década y la idea de patrimonio también, pero tendemos a asumir este tipo de cosas como esenciales. Yo he escuchado aquí frases como decir, bueno nosotros tenemos diez mil años, doce mil años, es decir, eso no es nada de simple y no es nada de fácil justificarlo adecuadamente de un modo que no sea arbitrario, de un modo que no sea simplemente porque yo creo, porque yo pienso o porque en algún texto de divulgación lo he leído. Uno de los riesgos y uno de los problemas por no reflexionar en torno a este tipo de conceptos que los estamos usando con fuerza y le estamos dando peso político y a partir de las cuales estamos moviendo gente y organizando gente, uno de los problemas al no tener una actitud crítica es que tendemos a esencializar, tendemos a perder de vista que se trata de ideas, de realidades que son muy recientes. ¿Por qué esta discusión sobre patrimonio? Aquí se ha llegado ha hablar sobre patrimonio, pero quiero plantear otra pregunta que es anterior: ¿por qué patrimonio?, ¿por qué patrimonio en relación a lo étnico?

Una última idea, la idea de patrimonio como cultura-patrimonio es una modalidad de pensarse a sí mismo de la burguesía en los países capitalistas en el siglo XIX, en lo que es el marco de la construcción de los estados nacionales, allí surge entre comillas la cultura occidental, surge la noción de patrimonio en un sentido moderno, está íntimamente ligado al éxito de una clase social, burguesía industrial, Europa, EE.UU., por lo menos, y a la necesidad de una construcción de la nación que es el diseño político del estado-nación de esta modernidad de la cual se hace cargo esta burguesía. ¿La noción de patrimonio que acá usamos tiene algo que ver con esto?, ¿sociológicamente qué es?, ¿sociopolíticamente qué es este concepto en nuestro medio?, ¿qué tiene que ver en Chile hoy hablar de patrimonio indígena? Esta es una jornada de reflexión; yo quise reflexionar un poco especialmente sobre el concepto que funda esta jornada. 
Victoria Castro: Sergio Avendaño, Patricia Ayala, Ulises Cárdenas y yo mostramos mucho de lo que señalaban varios expositores aquí. Y es que los profesionales de las ciencias sociales somos, en el conjunto de la población urbana, gente más bien de clase media económica. Tenemos más menos apellidos distintos, pero no es gente de recursos, es de andar más o menos al tres y al cuatro. Por lo tanto aquí, y eso es un ofrecimiento a las comunidades, hay un tema de vocación, de vocación y amor por el trabajo que se haga, tanto en el terreno como para la enseñanza. Esto también puede contribuir a borrar o aminorar un mito histórico que existe en algunas comunidades, en algunas personas, y es natural que exista, de que los arqueólogos o los antropólogos o cualquiera que viene y que se interesa en el conocimiento, venimos para hacernos ricos y buscar oro; digamos si fuéramos buenos pirquineros y no cientistas sociales sí, podríamos a lo mejor lograr eso, es una cuestión que hay que discutir, aclarar más, analizar, pero creo que más o menos ha quedado demostrada la entrega y amor en lo que hacemos. En ese sentido me parece que Carole (Sinclair) lo expresó con mucho sentimiento.

Otro aspecto que me gustaría agregar del colega Mauricio Uribe, es que Mauricio ha sido bien humilde en presentar los resultados de su trabajo, ya que ha habido un aporte muy concreto y me consta porque fui parte también de los grupos de trabajo de Mauricio hasta ahora último, en lo que puede ser catalogación, limpieza y ordenamiento de los materiales para el Museo de Caspana, que estaban en mal estado antes de que Patty Ayala, Varinia Varela, Mauricio Uribe, Leonor Adán, en fin, pusieran un orden, limpiaran y se preocuparan por que quedaran bien para la comunidad, como una actividad fuera del horario de trabajo. Hay varios ejemplos también de esa naturaleza, un poco también en el sentido de los aportes.

Respecto a la exposición de Caspana, a mí me sugiere una pregunta que me gustaría que profundizaran las autoridades de Caspana, por qué ellos señalan que no tienen sus derechos saneados, sus derechos tradicionales saneados, sería importante saber por qué eso pasa en algunos lugares con tanto tiempo, cómo que no resulta el asunto.

Con respecto a la exposición de Quillagua, la exposición de Carlos (Carrasco) que fue muy clara, la gente no se siente indígena, se siente de Quillagua. Quillagua estuvo a punto de desaparecer, naturalmente por el problema del agua, pasa el río Loa por ahí, pero sería ridículo contarles a ustedes que pasa con el agua de la Segunda Región. Hay algunos estudios que quedan guardados en las universidades y que a veces es bueno que lo conozcan distintos colegas, y por otro lado las comunidades. De hecho hay una práctica profesional de un antropólogo social que trabajó con la gente de Quillagua que quedaba, y la gente de Quillagua tiene orígenes en las familias antiguas que son de tierras a veces del Salar de Atacama. En fin, es bueno a lo mejor dárselo para que lo conozcan, no para que se conviertan en indígenas, eso es asunto de ellos, pero que se note que son poblaciones más de tierras altas.

Un tema que vamos a tener que discutir es el tema de los impactos ambientales y algunos desconocidos para el Consejo como el de la minera San Cristóbal que decía Wilson porque son graves, pero además las cosas son tremendamente burocráticas en Santiago y eso a lo mejor está en la CONAMA, porque no ha aparecido por el Consejo, es algo que vamos a averiguar. Pero no es solamente ese caso el problemático, los jóvenes de la comunidad de Lasana, que son del valle de Lasana, han presentado un tema bien importante en términos de todos los proyecto que tienen y yo creo que todos los que estamos aquí nos podemos ofrecer para, si nos necesitan, ayudarlos, apoyarlos en cualquiera de las cosas que quieran hacer, en términos del tema de la construcción de identidad que es tan complejo y que hay que reflexionar. Por ejemplo, una de las personas que habló es hijo de una de las personas que viene de las tierras altas y hay varios pobladores de Lasana que vienen de las tierras altas y a lo mejor ustedes mismos podrían hacer un estudio de cada uno de los parientes de donde vienen y a lo mejor conocer que hay mucho más riquezas y diversidad como lo planteaba el colega Gundermann. Esto porque la mayoría de la gente que llegó a Lasana de arriba es quechuaparlante, o fueron sus abuelos quechuaparlantes y hay varios encuentros culturales en Lasana, es bonito como en el fondo se está formando ese poblamiento del valle.

Creo que la exposición de Hans Gundermann ha sido muy profunda y a pesar del poco tiempo que tuvo ha dado unos buenos raspacachos a los arqueólogos, y me parece bien que podríamos incluso ver la conveniencia de juntarnos para analizar una serie de conceptos, porque todos sabemos que ninguno de los que estamos aquí pertenezcamos a la comunidad, sea indígena, mestizo, es un objeto estático de museo. Hay esa dinámica de construcción de identidades permanentes, es un proyecto, ir cambiando. Entonces creo que lo que dijo da para profundizar, analizar, que sé yo, incluso con los temas que tienen que ver con nuestro mestizaje. Muchos de los que conforman las comunidades indígenas algunos son de raíz más indígena, algunos tienen más mezcla y entre nosotros sucede lo mismo, no es por nada que al Álvaro Romero y a mí -y ninguno de los dos tiene ningún problema, al revés- nos preguntan de qué comunidad venimos, somos más evidentes, porque nuestro físico es más cercano, pero hay muchas otras personas que tienen el tema del mestizaje, entonces también tienen una situación de ambivalencia a veces con todo este tema de la cultura y el patrimonio, hay tanto que reflexionar.

Y por último quisiera señalar antes de dar acuerdo a la discusión, que hay un tema que se evidencia urgente, y no sé como lo vamos a poder hacer, pero es el tema de la agilización y nexos de las comunidades y comunicación con el Consejo de Monumentos Nacionales. Eso es una cuestión más que clara, así es que ese es uno de los temas que sería bueno discutir. Entonces puede que esta síntesis de preguntas sugerencias, etc., por favor podemos entrar a la discusión de lo que se ha escuchado. Se ofrece la palabra.

Donald Jackson: [Respondiendo a lo que dijo Hans Gundermann] No es el patrimonio lo central, es lo cultural y cómo definimos lo cultural. Yo creo que la gran mayoría somos bastante críticos, pienso que cuando nosotros definimos lo cultural recién podemos definir ese patrimonio. Doy un ejemplo: yo trabajo en la costa, trabajo sitios arqueológicos en la costa y la gran mayoría de mi evidencia cultural son conchas del mar, los moluscos que antes se botaban y hoy se estudian. En la medida que hemos construido que esas evidencias, son evidencias culturales, entonces se constituye como patrimonio, como patrimonio de los arqueólogos.

Yo creo además que el patrimonio es una construcción social como el mismo Hans lo dijo, y en ese sentido cualquier comunidad sea indígena o no indígena o la misma comunidad de los científicos, arqueólogos o antropólogos o de cualquier otro tipo, ellos construyen su patrimonio, construyen su identidad, y la pueden construir con quiebres históricos o sin quiebre históricos, lo importante es que exista. No la podemos valorar, creo que las construcciones sociales son paradigmáticas, esas construcciones son lo que la comunidad es y la comunidad es lo que dice ese paradigma y en ese sentido yo estaría en desacuerdo en esos puntos con mi amigo Hans y ese punto no más quisiera aclarar.

Y para terminar también quisiera abordar otro punto, aquí algunos presentes han hecho denuncias contra los arqueólogos y yo quisiera aclarar que como presidente de la Sociedad Chilena de Arqueología, que no todos los arqueólogos chilenos están en la Sociedad, en primer lugar. En segundo lugar, como presidente yo estoy dispuesto a buscar la información y hacer las 
gestiones de todas aquellas situaciones inadecuadas que se han presentado; pero para hacer eso yo necesito documentos escritos, es decir, denuncias escritas, nosotros como cultura occidental no funcionamos con la oralidad, funcionamos más con el documento escrito. Yo no puedo ir al Consejo de Monumentos Nacionales y decir, mira sucede esto que fue mal hecho porque me lo dijo tal persona, yo necesito llevar un documento que me respalde y precise las situaciones que se han presentado. Les puedo pasar a los miembros de las comunidades una tarjeta como presidente de la Sociedad para que tengan la dirección y me puedan escribir y me puedan mandar los documentos que sean pertinentes.

Un tercer punto, y perdón que me extienda, también se han planteado de manera tangencial y también de manera directa, que los arqueólogos, somos en general los responsables de la destrucción o el deterioro del patrimonio cultural o de gestiones mal hechas, yo reconozco que históricamente ha ocurrido así, pero se ha ido mejorando muchos aspectos; pero también quiero señalar que el patrimonio arqueológico más bien ha sido sometido a deterioro o destrucción por mucha otra gente que no se ha mencionado aquí, incluso por las propias comunidades porque a veces por una falta de conocimiento, porque yo puedo entender a veces, la visibilidad de un sitio arqueológico a veces no es evidente, se puede identificar, tal vez, fácilmente una construcción, pero no así un taller lítico o evidencias mucho más sutiles. Yo antes de venir aquí a Ollagüe pasé por Chiu-Chiu y me topé con varios sitios que se habían convertido en potreros. Yo creo que, y no quiero echarles la culpa a las personas individuales, la protección del patrimonio arqueológico es un deber de todos los ciudadanos, nadie puede estar excluido. Con eso termino.

Pablo Moreno: Mi nombre es Pablo, soy estudiante de la Universidad de Chile, no estoy invitado pero vine igual, yo quería hablar de un tema que no se ha tocado, que es el tema de la dominación a la que están sometidas las comunidades, o sea es un tema importante, recordemos que Diego de Almagro fue recibido a flechazos en el Pukara de Quitor, entonces esa historia de resistencia yo creo que la deben rescatar las comunidades e independizarse un poco del yugo de Santiago; el señor de la CONADI planteaba la ley, pero creo en una independencia política de las comunidades y que ellas elijan su destino en lo que debería suceder y no estarse sometiendo a leyes que son impuestas desde afuera; eso no más, gracias.

Roberto Mamani (Comunidad Atacameña de Larache): Soy atacameño por adopción. Soy estudioso de los ancestros de la altitud por devoción y quisiera hacer un comentario con respecto a la intervención de Hans Gundermann, en general me parece que tú intervención como te lo dije personalmente, me parece más controversial que estimulante. Quiero señalar por ejemplo que en los conceptos de cómo idear una cultura Hans no mencionó una posibilidad que es la que yo entiendo corresponde a la cultura andina, que es una cultura que obedece a principios cosmogónicos en sitios que fueron concebidos hace ya miles de años y que han servido para estructurar el mundo político, religioso, económico, incluso métrico de lo que conocemos hoy día como la Cultura Panandina. Me parece que esa idea de la cultura no fue mencionada y que es importante.

No creo que la cultura pueda ser por consenso, no creo que la cultura pueda ser simplemente por costumbre, tampoco creo que la cultura pueda ser el resultado de una ley que en algún momento pudiera ser creada. De tal suerte que yo quisiera plantear esta posibilidad de que la cultura tal cual se concibe es una cultura que tiene sus orígenes en principios cosmogónicos. Ahora este paradigma me permitiría por ejemplo decir que evidentemente la comunidad de Lasana tiene su origen en el mundo andino, prueba de ello por ejemplo es la fiesta de la Cruz de Mayo, que evidentemente lo que se está celebrando es que la cruz del sur en esa fecha alcanza su mayor cenit, justamente en esa fecha la comunidad de Lasana está celebrando la fiesta de la Cruz de Mayo, y cuando nosotros nos vamos hacia el Pukará de Lasana nos encontramos que una de las construcciones más interesantes, que era la construcción donde se supone estaba el jefe, el sacerdote, que era la persona que dirigía la comunidad, esa pieza estaba adornada con el símbolo típico que corresponde a la cosmogonía del mundo andino que es la cruz del sur y es precisamente de este juego de luces y de sombras por el cual nuestros antiguos podían establecer la ciclicidad del año y establecer cuándo había que cosechar, en fin una serie de hitos muy importantes, eso.

Hans Gundermann: Muy breve en honor al tiempo. Creo que la controversia es estimulante, por lo menos para mí es muy estimulante, quise hacer un planteamiento controversial, precisamente, para estimular la conversación y eso es bueno, grato y aunque parezca mal o alguien se desquite, no hay problema.

Verónica Moreno (Programa Orígenes): Estaba recordando cuáles serían algunos canales como para participar, para personas que han trabajado en comunidades y que por lo que se ve, especialmente los jóvenes o los más mayores tienen una disposición al cambio, a tener una disposición nueva, diferente de trabajar. Yo quería decir que uno de esos canales que funciona ahora, por lo menos sirve para juntarse y para poder coordinar algunos trabajos, son las reuniones que tiene el Área de Desarrollo Indígena Atacama la Grande. Como ustedes saben se creó hace un año y esas reuniones se hacen una vez al mes y bueno, nosotros podemos ponernos de acuerdo y yo sé que esas invitaciones llegan a museos, en el caso de San Pedro. En el caso del Alto Loa todavía no existe pero está la propuesta que se cree un área de desarrollo y las personas que tengan interés estén bien acogidas y parece que eso funciona, algo y eso también ayudaría a la coordinación. Otra cosa, yo creo que sería un buen ejercicio práctico.

Ángel Bravo: Voy a ser bien concreto, Donald (Jackson) habló acá de algunas situaciones de denuncia del patrimonio, yo dije en la mañana que venía representando a la municipalidad y nosotros estamos muy preocupados con lo que pasa con el patrimonio al interior de la comuna y voy a puntualizar algunas cosas necesarias. Por ejemplo el grupo de Carolina Jiménez mencionó las colecciones que trabajaron ellos en el Museo de Calama con Topater. Yo el año 1987 fui conservador de los museos del Loa y a mí me tocó ingresar precisamente las colecciones que estaban en la ex casona municipal, allá en el edificio consistorial en la bodega del parque El Loa. Las colecciones que ustedes vieron son la mitad de lo que había en aquella época y hay que rescatar las cosas que hizo George Serracino, que fue el arqueólogo que estuvo trabajando en el cementerio Topater, que después retomó Carlos Thomas en Santiago. Yo no sé cómo va ese cuento. Yo quiero llamar la atención sobre ese punto porque sería importante ver qué pasa. Una cosa.

Después los hermanos de Lasana entre todas las destrucciones que allí mencionaron, no mencionaron cuando se ensanchó la vía que une Chiu-Chiu con Lasana y allí había una cantidad de petroglifos que estaban casi cayéndose y hoy día no están. Entonces yo quiero hacer la pregunta: dónde están esas colecciones, quién es el responsable, qué paso con ese material porque no es novedad que haya gente inescrupulosa que a veces agarre verdaderos peñascos y los venda, qué sé yo.

El tercer punto de atención. Yo dije que San Pedro de Atacama está pasando por una situación complicada, porque la excavación que se está haciendo por el alcantarillado no están cumpliendo los requisitos que deberían existir en todas las excavaciones arqueológicas, voy a hacer llegar a Donald perti- 
nentemente los informes que estoy realizando, porque allí siendo la capital arqueológica de este país, la gente está viendo cómo se excava, y se excava de mala manera. Yo insisto acá, no son los ayudantes del museo, a quienes yo considero amigos, los responsables de esto, sino que creo que son los investigadores que deberían estar a cargo de la excavación de rescate que se está haciendo allí, eso yo creo y soy bien enfático.

Cuarto. En San Pedro de Atacama también hay un problema grave y que se refiere no solamente a que tal vez el Hotel Explora se construyó [...] sobre un yacimiento arqueológico, sino que hay ahí una cosa mucho mayor. Se habla hoy en día que los museos deben ser entidades que organizan comunidades, gente especializada; qué pasa con ese museo que está en el sótano del Hotel Explora, quién ha autorizado eso, qué pasa con esas colecciones, eso es otro cuento que yo lo voy a hacer llegar como asesor cultural de la municipalidad de San Pedro a Donald en este sentido.

Hay dos elementos más allá que son gravísimos, hay gente atacameña que huaquea piezas y que vende piezas, vende puntas de flecha, vende una serie de cosas a los turistas que llegan a San Pedro de Atacama, yo respeto a las comunidades pero no he escuchado de parte de las comunidades un punto de atención sobre eso. Y por último, y con esto termino, en el mismo paseo peatonal que hay en San Pedro de Atacama que une la plaza con la calle Licancabur, hay muchas veces en que los artesanos que allí están, yo tengo mucho respeto por ese oficio, venden artículos que están protegidos por la Ley de Monumentos, por ejemplo todo lo que es el elemento paleontológico, allí los venden tranquilamente, y alegremente diría yo; he visto cómo venden elementos de la colonia elementos históricos; es muy fácil en San Pedro ir a los yacimientos y desenterrar llaves, desenterrar candados y venderlos alegremente, yo ya me he cansado de discutir sobre esa situación y la verdad es que yo sin tener arte ni parte en el cuento, sino más bien como investigador, termino a veces enemistado con la gente, o sea quién es aquí el que tiene que dar la voz de alerta; yo creo que en San Pedro de Atacama hay visitadores, hay gente que tiene que cuidar el patrimonio, yo esto lo estoy diciendo con mucha responsabilidad porque, insisto, cuando yo vine acá, la municipalidad me encargo de que velara por el patrimonio cultural. Eso, gracias.

Carlos Aguilar: Cuando partí en la mañana diciendo la importancia que para nosotros, la comunidad de San Pedro de Atacama, tenía participar en este encuentro al momento de hacer preguntas, creo que ha habido respuestas y ha habido respuestas de diferente tipo, independiente de lo que quisiera conocer yo más en la cosa personal como respuesta. Se ha mencionado que ha habido publicaciones, estoy hablando de los aportes que han hecho sobre los trabajos de arqueología, antropología. Eso es una cosa y que no tiene que ver con las excavaciones, con la recopilación, con el rescate, de algunas partes de enterramientos, sino que también tiene que ver con la información que tienen los miembros de las comunidades indígenas, la información que tenemos los jefes, y, bueno todo lo demás, en función de eso también hice la pregunta en cuanto a los aportes.

A la vez, volver a decir que esta intención de llegar aquí ya es un gran paso otra vez, tener la paciencia de poder convivir con este tipo de trabajo arqueológico, y todos los "lógicos". Otra pregunta más, quisiera saber si lo que está en territorio del pueblo lican-antai, ¿a quién le pertenece según la concepción de ustedes? Le pertenece a los dueños, ya sabemos que la costumbre constituye derecho. Bueno, hemos venido aquí para reflexionar sobre el tema, independiente que tomemos Coca-Cola o bailemos el sound. Bueno eso, gracias.

Victoria Castro: Antes de darle la palabra a Cristián quisiera comentar algo en forma personal que me preocupa, porque en- cuentro que es una cosa dialógica, una cosa natural que se establece entre seres humanos que es conversar sobre los conocimientos que tienen unos y otros. O sea yo puedo conversar sobre qué hay en la historia, qué conozco del lugar en que vivo, y la otra persona similarmente, y puedo devolverle la mano a la comunidad en el sentido de entregar algo que alguien me dijo y que alguien me contó y que yo se lo entrego para que se lo cuente después a personas que se van a criar en Calama, a lo mejor, podría ser.

Pero además Hans dijo el tema del aporte de la oralidad en el sentido de la construcción del discurso étnico, en el sentido de la construcción de la identidad y yo creo que eso es valioso, y yo creo que de alguna manera es algo que salió y que estaba guardado, que se conocía pero que ustedes retomaron, eso me parece que es lo que hay que hacer, pero es muy constructivo, no tiene por qué ser la verdad.

En cambio sí me preocupa mucho y lamentablemente creo que no hay ningún especialista de esa área aquí y es un tema tan delicado que en lo que se llama Consejo Nacional de Ciencia y Tecnología, el CONICYT, se está exigiendo a cada proyecto que tiene que ver con los bioantropólogos y estamos siendo mal mirados en ese sentido, por esos especialistas, pero es algo que hay que hacer, cartas de ética, de las instituciones, de las comunidades donde teóricamente se van a hacer los estudios, donde prácticamente se van a hacer los estudios o se van a usar datos que están guardados, se les está exigiendo que las comunidades sepan, porque ya todos estamos cansados y una cosa muy limítrofe con el tema de la ética, o sea no es una cuestión menor, es una cosa que está en el ambiente con mucha preocupación y en el ambiente nacional.

Por lo tanto es muy importante que si a alguna comunidad viene un grupo o de médicos, o de antropólogos físicos, es gente que estudia esto de los genes, se comuniquen rápidamente con cualquier nivel de autoridad para pedir, si existe el consentimiento de la comunidad primero, de qué se trata, para dónde va, etc., porque es algo demasiado delicado y perdón que haya tomado este tiempo para decirlo pero quiero decir que es un tema que nos preocupa a todos.

Y lo otro, yo reconozco que es probable que a cualquier persona que esté en su casa le cueste convivir y tener paciencia con los "lógicos", por otro lado esto es parte de la dinámica de un país, o sea algo que existe y ustedes a lo mejor tienen que tener, a lo mejor, igual paciencia, menos paciencia, más paciencia con toda la gente que ha venido foránea a hacer su comercio; ese es otro tema, entonces es una cuestión que pasa, es una cuestión que está en el mundo que vivimos, esa es mi forma de ver.

Carlos Aguilar: Lo que he dicho sobre esta información genética tiene que ver sobre este simposio que se hizo hace algunos años atrás y que tuvo que ver con antropología, arqueología, medicina y ahí ya hubo un trabajo en el cual la gente del pueblo lican-antai fue usada porque ¿de dónde han sacado esa información de los vivos que están clonados ¿no? Es de gente que vive en los pueblos, entonces ahí hay una atención bien importante que hacer. Bueno, como estamos en la reflexión, en la conversación y con la disposición de poder seguir conversando sobre este tema, sobre muchos temas más, también tenemos el efecto del turismo sobre el pueblo, cada vez hay una mayor influencia como lo decía en la mañana con muchos trabajos que así entre comillas llegan a poner valor o revalorizar, eso.

Cristián Catricura: Con respecto a genes humanos nosotros como CONADI estamos muy preocupados, inclusive denunciamos a un antropólogo a la Comisión de Ética de la Universidad de Chile, ante el rector de la Universidad de Chile, por el proyecto vampiro. Nosotros le llamábamos así en la zona 
Huilliche porque se sacaba sangre y se llevó a estudiar a una universidad de Estados Unidos, lo denunciamos y está en investigación todavía. O sea, la preocupación nuestra está.

Ahora, nuevamente Chile como Estado no ha ratificado esta convención internacional, sí los pueblos indígenas de América lo tienen ratificado, la convención que se dio con el pueblo Cuna. Con respecto a lo que planteaba acá el hermano de San Pedro, la Ley de Monumentos Nacionales dice claro que cualquier persona puede denunciar, yo di un caso de la reforma procesal donde nosotros recuperamos todo un sinnúmero de patrimonio cultural, o de restos arqueológicos, paleontológicos, etnográficos. Ustedes tienen la reforma procesal, tienen que hacerlo ahora, para eso están los fiscales, si ustedes quieren la pauta tienen que ir a Consejo de Monumentos Nacionales, o el mismo consejo puede hacerlo, ya lo hizo, ya ellos fueron los que denunciaron y se hizo toda esta escalada de recuperación del patrimonio cultural mapuche.

Y tomando en cuenta también otra aseveración que me dolió, aquí participó mucha gente, no estaríamos aquí, porque fuimos los mismos indígenas que luchamos por esta ley y porque estuviéramos acá. Nada se nos dio gratis, aquí atacameños, quechuas, mapuches, aymaras, kaweskar, huilliches, rapanui lucharon para que saliera una ley, esto fue una lucha política, el Estado no te lo dio. Aquí hermanos mapuches fueron relegados, aquí entonces hay que tomar en consideración toda una raigambre histórica, nadie nos dio nada a nosotros los indígenas, eso estamos claro, pero algunos tenemos la institucionalidad en el Estado, en el Gobierno, pero igual estamos creando una política, si no se hubiera creado todo esto debido a la presión de las comunidades indígenas, de las asociaciones y de aquellos que fueron encarcelados por esta lucha, no estaríamos acá

Yo te lo digo, aquí Wilson (Galleguillos) sabe muy bien cuántas personas cayeron aquí del pueblo atacameño, entonces duele que esto no se diga, a lo mejor el hermano lo hizo sin intención, pero estos reconocimientos de los pueblos para nosotros es importante. Vienen pasos mucho más importantes como el convenio 169 , el reconocimiento constitucional y un montón de cosas que nosotros queremos pactar con el Estado. Pero si no hay una ley de por medio, como lo decía muy bien el hermano, si no hay una Ley de Estado Chileno, entre comillas, no podemos establecerla.

La relación ellos no la hacen, las culturas que están presentes y que antiguamente eran precolombinas y que están hasta el día de hoy, fue por la lucha de ellos, y la lucha que ustedes ven constante que nosotros tenemos, que el pueblo mapuche lleva, no es gratis, ustedes ven los altos costos que ellos tienen. El pueblo lican-antai está en su lucha por salvar el patrimonio, va a ser un camino arduo, el pueblo mapuche está por la recuperación del territorio, acá pueden ser otras reivindicaciones, pero cada pueblo está llamado a decir su historia. Nosotros no podemos imponer la cultura superior, la cultura occidental que es lo que quiere hacerse en cada pueblo, pero esto es un proceso que es histórico, en el cual nosotros podemos plantear al Estado, llamar aquí a las sociedades científicas, llamar a entes de gobierno y decirles en su cara lo que se podía hacer.

Hace quince años atrás no fue así, y así es como encarcelaron a una cantidad de dirigentes indígenas que inclusive llegamos a estar de igual a igual en la alianza democrática, cosa que las personas mayores pueden recordar quiénes eran esos dirigentes, fue una lucha de años; y todos los que están luchando ahora, que cuando ellos hablan del etnoturismo, de administrar los sitios, eso no se los están dando, no esta papá Estado diciendo toma, ahí tenis el sitio te lo damos; están luchando, están negociando, entonces esa negociación no es gratis.

Yo encuentro que todo lo que están haciendo es bueno, hay que tomar los instrumentos del Estado, las leyes que están presentes el día de hoy, respetarlas de acuerdo a la conveniencia de nosotros como indígenas, ¿cierto?, quién nos va a decir a nosotros, a lo mejor hay hermanos indígenas que están muy bien por la causa nuestra, y quieren ayudar y cooperar, pero somos nosotros los llamados a que esa causa se encamine y por los deseos que nosotros queremos. Aquí es administración de sitios arqueológicos, en otros lugares otras cosas, aquí derechos de agua, allá es derecho territorial. Ahora ustedes de acuerdo a su visión, de acuerdo a su estado de relación, es lo que tienen que implementar, costó mucho implementarlo nuevamente.

Hay que mejorar, si hay que criticar critiquemos, pero todo esto no se podría llevar a cabo sin un sinnúmero de gente que no hubiera dado la cara y no hubiera estado y no hubiera sufrido muchos colapsos que se dieron. A veces uno se olvida de la memoria histórica, no está, pero eso pasó, ahora hay que tenerlo presente, no agotarnos con el pasado, sigamos adelante, pero el pueblo lican-antai, el pueblo quechua, los hermanos aymara, todos los indígenas van a trabajar de acuerdo a lo que ellos estimen conveniente, cierto, y esa conveniencia va a ser la relación que tienen que hacer con el Estado, tomar los instrumentos legales, insisto, tratar de interpretarlos, presionar en algunos sentidos, para que todo lo que ustedes quieran se pueda lograr. Ustedes ven que en todo este proceso de años se ha avanzado una enormidad, se podría avanzar mucho más pero va en cómo las comunidades indígenas dialogan con los diferentes entes, tanto privados como de gobierno, para poder desarrollar su proyecto, y cada pueblo tiene su proyecto, eso.

Wilson Galleguillos: Hermanos, yo no creo que un pueblo pueda vivir aisladamente, yo creo que necesita convivir con otros, somos seres humanos, nosotros no estamos en contra de las ciencias sociales, queremos trabajar juntos, bajo ciertos parámetros de confiabilidad, de respeto. Nosotros creemos firmemente que vamos a llegar a un buen término para que de esa manera el pueblo lican-antai permanezca por mucho tiempo más. Es cierto que a muchos de ustedes sin ser atacameños les gusta la cultura atacameña, vibran con la cultura atacameña, y me atrevo, incluso, a decir que algunos han encontrado mucha paz, mucha espiritualidad en el mundo andino. Yo insto, invito a que se respete la Ley Indígena que en uno de sus articulados dice claramente y expresa que cualquier tipo de intervención, llámese patrimonio cultural arqueológico, debiera contar con el previo consentimiento de la comunidad involucrada, yo espero que eso se cumpla.

Por otro lado también sería conveniente a través del organismo, no sé si algún colegio, universidad o el mismo rector, se gestionen o llegue a un acuerdo con las comunidades, que exista un interlocutor válido para nosotros, porque muchas veces llega un arqueólogo, un antropólogo y no sabemos de qué lugar es. Entonces creo que sería interesante formalizar un conducto regular, pertinente.

Y por otro lado también voy a decir con respecto al hermano de San Pedro de Atacama, porque creo que para mí hay buenos profesionales, como hay malos profesionales, hay doctores malos y doctores buenos, doctores que matan y otros que sanan, en todos los campos existen. Entonces yo quisiera tomar el tema nuevamente porque yo vi personalmente, lo vi con mis ojos, yo penetré en el Hotel Explora y con otro hermano que está aquí presente, vimos cosas que son de San Pedro de Atacama y no como ellos dicen o dijeron que eran de otro lugar, es mentira, esas piezas son de aquí; por eso insisto nuevamente, en que hay que seguir una investigación para llegar a feliz término. Y es más, me atrevo a decir que en aquel directorio hay profesionales que tienen mucho que decir y que están involucrados, estoy seguro de aquello, pero a lo mejor el hombre no lo va a castigar porque el hombre no castiga como corresponde; sin embargo la naturaleza, la patahoiri, la madre 
tierra que es sagrada, ella le dará a cada cual lo que es justo, y por eso es que a mí me da mucha pena muchas veces cuando veo grandes hombres, estudiosos, que, por lo menos, la madre tierra no les va a cobrar en plata, les va a cobrar su vida, por último les va a quitar la vida, porque a la madre tierra se le paga con sangre. Quisiera finalizar diciendo que el que hiere a hierro a hierro muere, muchas gracias.

Victoria Castro: Yo sugiero Wilson que como una persona importante dentro de la comunidad indígena y con las otras personas que puedan acompañarte hagas la denuncia al Consejo de Monumentos Nacionales, por escrito, se pueden mandar fax y cartas, documentando todo esto en forma clara para que se proceda a un estudio, un análisis de la situación, yo creo que vale la pena el trámite. Tomo este ejemplo, pero tantas veces como sea necesario, cuando hay tanto este tema de los estudios de impacto ambiental a veces tomar conocimiento de cómo se esta haciendo, qué se yo, y si hay algún reparo hacer las consultas pertinentes, porque la única forma de aclarar las cosas y de llegar a una certeza de que las cosas son de buenos doctores o de malos doctores, diciéndolo en tus términos, o si es correcto o no, es a través de las consultas, las preguntas, qué se yo, que un organismo estatal tiene que responder, en este caso, al menos en lo que atañe al Consejo de Monumentos, yo creo que hay que hacerlo igual.

Sara Plaza: Yo sólo quisiera hacer una pregunta, porque nosotros, como le contaba, tenemos sitios arqueológicos bien importantes, que ya un circuito hemos cerrado. Es una pregunta ya que acá hay arqueólogos, bueno, distintos estudiosos, también Monumentos Nacionales, nosotros queremos cerrar las Pinturas de Peine para poder velar, porque cada día lo vemos desgastado, borrado, a veces los turistas llegan, sacan los pedazos o quizá qué personas le sacan otro pedazo y al final se está yendo en pedacitos, nosotros no podemos cerrarlo porque está declarado Monumento Nacional y tenemos un cierre que tiene la puerta abierta que todo el que llega entra. Eso era una pregunta, ¿qué podemos hacer nosotros?

Igual que Peine Viejo cualquiera llega no más y se puede quedar, hay muchas excavaciones y ahora nosotros no tenemos una persona estable que cuide esa parte, así es que estamos donde mismo, pienso, en el aire, ni siquiera nosotros sabemos quién ha ido y quién ha excavado. Esa es mi pregunta, qué podemos hacer nosotros, si no podemos cerrar, cuál es la instancia más fácil que llegue luego a Monumentos Nacionales.

Victoria Castro: Perdón, yo creo que en ese caso, que es tan concreto respecto de dos situaciones, ya que lo han escuchado aquí más de cuarenta personas, podríamos presentar con María Teresa Planella, o llegando a Santiago una carta para mandarles sí existe una normativa que ustedes puedan emplear. O si es necesario todavía que ustedes manden la carta, etc., para este tipo de consultas. Nosotras agilizarles el trámite, mandándoles de allá a la comunidad de Peine un instructivo de qué hacer y de qué pasos seguir. Me parece lo más sencillo, no sé si respondo la pregunta... muchas gracias. Cristián por favor de Lasana.

Cristián Pérez: Quería a usted responderle de los petroglifos de Lasana. Creo que esta situación ocurrió hace dos años atrás, yo aun no estaba participando activamente en la comunidad, era menor de edad no estuve al tanto, pero sí creo que hubo una investigación al presidente de la comunidad en ese tiempo, bueno por este motivo y por otros más, tuvo que dimitir su cargo, tuvo que irse. Pero yo personalmente aún no estoy muy claro en eso, pero sí me comprometo a investigar lo que pasó, no sé, conversar en otra ocasión.

En cuanto al segundo punto, lo que decías tú, Pablo Moreno, que decías por qué no nos liberábamos de tantas trabas, bueno recordemos, él mismo lo dijo, cuando llegó Diego de Almagro acá, lo recibimos a flecha y nos cortaron las cabezas, luego nuestro gran líder, Tomás Paniri, en 1781, ahí lo ahorcaron. Si nosotros queremos liberarnos de todo esto tendríamos que liderar una fuerte lucha, tal cual lo hacen los hermanos mapuches en el sur, tal como lo hicieron en México, creo que es una lucha que aun, personalmente creo, no podemos hacerla, pero sí tener la idea de que algún día el Estado chileno nos pague la deuda histórica que tiene, porque desde que Colón llegó a América hemos estado perdiendo nuestra identidad poco a poco, nos han matado, esto ha sido un etnocidio con nuestra cultura. Y otro punto que tocó acá Wilson, el asunto del Hotel Explora, yo estuve también con él mirando en el subterráneo que tienen ellos los objetos arqueológicos, me parece que sí se debieran tomar cartas en ese asunto, de que esas cosas deberían volver adonde estaban.

Y otro punto, un asunto muy personal, me gustaría preguntárselos a los arqueólogos que ellos trabajan mucho con nuestros ancestros, desenterrando momias. Yo visitaba el Museo de San Pedro me daba pena ver un cráneo en la vitrina, yo creo que a nadie le gustaría que cuando se muera después le profanen sus tumbas, que sea mostrado en una vitrina, en un museo, creo que podemos mostrar artefactos líticos, textiles, herramientas que fueron de nuestros antepasados, pero no a ellos, yo me opongo terminantemente a aquellos arqueólogos que exhiben esto en museos, que exhiben cráneos, que exhiben cuerpos, creo que eso no debería ser. Eso sería todo.

Ricardo Vilca: Bueno, para finalizar yo creo que hemos estado en una larga jornada, pero aquí tenemos que agilizar procesos, o sea cuando en la comuna de San Pedro de Atacama se ha dado énfasis en el turismo, para poder administrar a través de CONAF, las lagunas, los sitios arqueológicos, nosotros queremos que Monumentos Nacionales no sea burocrático con nosotros. Si nosotros hacemos la solicitud para construir una oficina, que eso, como dijo el Presidente Lagos, en siete días esté la respuesta, y de esa manera a través de cualquier servicio público de gobierno o proyecto de hacer oficina, hacer cierres, construir determinados centros turísticos, que primero esté CONAF con sus funcionarios para decir hagámoslo de esta manera, cierto, para que no exista burocracia. Como hoy día están todos los arqueólogos, todos los estudiosos, lleguemos a un acuerdo con una circular que sea clara y precisa, para que no haya burocracia en la comuna de San Pedro de Atacama.

\section{4 de Noviembre}

Carola Condarco (antropóloga, Universidad Técnica de Oruro): El trabajo que a continuación voy a presentar es acerca de una excavación que realizamos entre el 2000 y 2001 y que culminamos con la ampliación del Museo de la Cuenca de Paria. Es decir, teníamos dos fases dentro de este proyecto. En Bolivia, como dijo ayer Álvaro (Romero), más o menos parecido; se estaba optando por políticas de dar a los comuneros la oportunidad de acceder y llevar turistas a los sitios arqueológicos, como patrimonio de ellos. Un poco nosotros aceptamos cuando vino la convocatoria para este proyecto financiado por el ANDESES que trata de convocatorias regionales, es decir, por departamentos en Bolivia.

En la convocatoria decía: "mapeos de sitios turísticos, zonas turísticas, circuitos turísticos y restauración”. Esos trabajos ya se habían realizado por algunos arqueólogos en Bolivia, y digamos, no han sido muy acertados por la manera en cómo han sido refaccionadas las chullpa, no tienen un buen trabajo de conservación, les han puesto el techo de paja, han hecho aceras alrededor y les han puesto barro con mallas de alambre. Entonces, a mí me parece, es hasta más lindo ver las ruinas, las chullpas, al trenzado del adobe, pero se han hecho 
esas cosas, no sé con que criterio, además que en todas partes esto está también supeditado por la política, por partidos políticos.

A mí me llamó mucho la atención la convocatoria del Programa de Investigación Estratégica en Bolivia (PIEB), y yo me atreví a lanzar un proyecto, hacer una investigación arqueológica y paralelamente hacer un museo con los restos arqueológicos que se pudieran lograr en la excavación. Y bueno, sacamos el proyecto, de 168 proyectos que participaron, salieron ocho proyectos. Ahora quieren apuntar a eso, a proyectos de desarrollo, trabajos alternativos en las comunidades.

Yo tenía que vender mi proyecto, teníamos solamente seis meses para hacer el museo, hacer excavaciones, todo en seis meses. Había tenido entrevistas previas con los comuneros antes de presentar el proyecto para hacer el museo, les dije que quería hacer este proyecto, que también quería hacer el museo y que también podíamos vender artesanía. Allá hay mucha arcilla, podíamos hacer, ellos son agricultores y perciben ingresos temporales. Debimos combinar las fechas en que ellos no tenían ocupación para hacer artesanía y venderla en el museo. También hemos realizado un video sobre la excavación, nos falta la edición para poder venderlo también en el museo; y tienen otros proyectos más a partir de este proyecto que hemos iniciado.

Les voy a contar a grandes rasgos de qué trataba, sobre las comunidades y el patrimonio. La investigación arqueológica era acerca de la hipótesis de John Murra del control vertical de pisos ecológicos. Esta idea fue anterior a que Murra trabajara con Danilo Condarco, anteriormente fue Murra, y yo la retomé porque en excavaciones que he realizado he encontrado elementos foráneos, mucha concha marina, lapislázuli, y eso me llevó a hacer este proyecto.

La cuenca de Paria es un altivalle, contrario hacia al valle cochabambino, ahí estaba el Tambo Inka de Paria que creo que lo he ubicado. John Hyslop dijo ya en el año 1969 que estaba 5 km más abajo del asentamiento que vamos a ver, yo creo que lo he ubicado porque tiene estructuras muy importantes. Es un asentamiento, el más grande del siglo XIV en Oruro, $5 \mathrm{~km}$ más abajo que Tambo Caril. Con todos estos asentamientos, el Wankarani del período Formativo, que ya había trabajado, y el Inca, que era nuevo para mí, pero que no podía dejar de excavarlo. Con siete arqueólogos nacionales, bolivianos y extranjeros y como le decía ayer a don Carlos, no se ve nada, sólo piedras, ¿Cómo he logrado ver yo las 50 hectáreas?

Parecía un asentamiento importante, tenía el financiamiento, podía aprovechar para hacer algunos estudios para llamar la atención de los investigadores que quieran seguir trabajando aquí. Entonces en el período Formativo y en el asentamiento incaico hemos encontrado una serie de elementos foráneos, conchas marinas de mucha variedad, visiblemente utilizadas como elementos ornamentales, rituales y lo mismo en Paria. Con esto tenemos una secuencia hasta el incaico, además que la cuenca de Paria es un enclave estratégico por el paso valle-costa hacia el Pacífico, y eso fue reutilizado por los Soras, posiblemente en Paria, por esas características geográficas, después fue como un centro, un enclave ecológico.

Después de los Soras llegaron los Incas, después de los Incas llegaron los españoles, entonces tenemos esa hipótesis con la que estamos trabajando, que es un enclave ecológico, que está seguida por la situación geográfica. Por eso también fue fundada Paria, en el pueblo histórico de Paria los españoles tenían víveres, ropas, facilidad para moverse por los caminos incaicos y se fundo Paria en 1585. Ese es el trabajo de la investigación arqueológica

Hemos hecho un levantamiento topográfico a partir de los montículos de piedras que teníamos, el panorama en Paria la India, que así se le conoce en el documento etnohistórico, o Paria la Vieja, tenía construcciones de piedra, morteros de barro, todo se derrumbó antes de levantar el montículo, por eso es que a simple vista parece que no hubiera nada. Pero al excavar en los montículos más pequeños hemos encontrado estructuras incaicas, en los más altos tenemos una superposición de estructuras, lo incaico y lo colonial.

El museo se pensó hacer en la comunidad donde tenemos el balneario de Obrajes de aguas termales. Se adecuó este lugar para que sea museo y tiene 14 por $10 \mathrm{~m}$. El museo está pensado para los alumnos, tanto de las carreras Antropología como de Arqueología, a los alumnos para enseñar a los alumnos un fragmento de la historia local. Gracias.

Justino Cancina: Buenos días a todos, primeramente ya me presentó Axel y voy a volver a presentarme. Mi nombre es Justino Calcina soy de la Comunidad de Santiago K, distante, bueno en kilómetros no lo puedo decir de acá de Ollagüe, pero estamos como a dos horas de camino. Se está llevando a cabo un proyecto denominado Altiplano Sur entre las comunidades de Santiago K y Santiago Chuvica, de mi compañero Bernardino Quispe. Bueno, la afluencia de turistas ha llegado a la ciudad de Uyuni con miras a conocer el Salar de Uyuni, los salares y las lagunas. Prácticamente se ha iniciado por propio interés de los comuneros este trabajo, como Axel explicaba, no hubo presencia de arqueólogos.

Nosotros estamos soñando a partir de los años noventa para poder insertarnos en el circuito turístico. A pocos kilómetros de nuestra localidad pasa una carretera que hace una jornada desde Uyuni a la Isla del Pescado, a la Isla Incaguasi, en el salar de Uyuni, bueno, pasando a descansar en la comunidad de San Juan, solamente el turista viene a ver el salar, la isla, los cactus, etc. y no ve otra cosa más. Entonces en este sentido mi persona más que todo ha ido gestionando, tramitando, yendo a la Universidad Mayor San Andrés de La Paz, yendo a la ALPES, al Instituto Nacional de Antropología y Arqueología, ahora Unidad Nacional de Antropología y Arqueología, y me pareció que no había proyectos.

Tampoco de la comunidad se podía viajar porque demanda mucho recurso, de manera que nos topamos con Axel justamente cuando él llegó a mi comunidad y la desesperación que tal vez nosotros tuvimos de ya no más, nosotros tuvimos la necesidad de revalorizar las chullpa, el patrimonio que tenemos de nuestra tierra. Pero sin embargo, cuando se gestiona ante las autoridades gubernamentales el caso no es de trabajar en forma clandestina, tiene que tener sus específicas funciones en cuanto a que es el trabajo, la excavación arqueológica. Posterior a eso hemos pedido hacer que se firmara un convenio con los voluntarios argentinos con los que vienen a trabajar con la supervisión y con la contraparte boliviana como codirector.

Trabajando en el año 1998 donde han trabajado diez arqueólogos y un fotógrafo; entonces de manera que ahora lo que nosotros estamos esperando es el trabajo llevar adelante para insertarnos en el circuito turístico, ya tenemos los senderos, ya hemos habilitado un poco pero son bien exactos. Aún todavía nos falta la capacitación de los guías turísticos y la verdad es que un poco ya Axel ha explicado que cada año viene aumentando la llegada de turistas. Por otro lado, también mencionarles que los trámites son algo burocráticos, pero sí avanzan, lento pero seguro.

Hace rato los compañeros de Oruro han mostrado donde dice un turismo planificado y nosotros queremos estar insertos en un turismo planificado. Yo también soy un chofer o guía de turismo, yo trabajo en una de las agencias de Uyuni, conozco la zona, he ido hasta San Pedro de Atacama, entonces también he captado ideas, la inquietud que tienen los turistas. Por decir, el año 1999 a Uyuni han llegado algo más de 22 mil turistas, el año 2000 han sobrepasado los 24 mil turistas, tanto los que llegan a Uyuni como también los que salen de San Pedro de Atacama por la Reserva Avaroa, por Laguna Colorada hasta Uyuni. Simplemente es contarles y también mencionarles de 
hacer un turismo coordinado tanto con Bolivia y Chile, que se podría planificar de la mejor forma posible haciendo este tipo de encuentros.

Este encuentro a mí me parece muy bonito y muy interesante que nos estamos llevando buenos recuerdos y también buenas experiencias que han tenido otras comunidades y por otro lado también mencionarles siempre preservar la parte ecológica, esa es una parte muy peligrosa para las comunidades. Por supuesto que nosotros estamos en una zona donde producimos, no será a mayor escala y somos productores de quínoa, la quínoa real que me gustó mucho anoche que hayamos comido. Yo no soy de mucha palabra, pero sí estamos en esto de tratar de llevar adelante para mejorar el nivel de vida de cada poblador en nuestras comunidades, ofrecer nuestros sitios arqueológicos, ofrecer nuestra propia artesanía, ofrecer nuestra propia comida. Yo creo que eso es lo mejor, el turista quiere ver una cosa que el no ha visto en su país, que nunca ha visto. El turista quiere informarse qué es lo que ha pasado hace doscientos, trescientos o mil años atrás, entonces eso es la experiencia que yo he vivido en muchos viajes y para terminar, muchas gracias.

Bernardino Quispe (Comunidad Santiago Chuvica, Bolivia): Hermanos, buenos días, ustedes ya conocen mi nombre, yo soy Bernardino Quispe, yo no soy ningún profesional. Nosotros somos solamente comuneros que hemos venido a sacar experiencia de estos encuentros. Bueno, a pesar de que tenemos poco tiempo vamos a relatarles de qué vivimos en el sector.

Nosotros somos agricultores de la quínoa, un poco de papa y ganado solamente. Al principio para usar el terreno imploramos a la Virgen y la pacha mama. Nosotros realizamos las costumbres tradicionales que seguimos manteniendo. En un principio damos una coa para que nos dé el producto correspondiente para nuestro sustento diario, producto de esto ya una vez cosechado, o ya cerca de la cosecha, el agradecimiento que le damos ofertando la fiesta del carnaval que justamente son los primeros productos que llegan en el año en los días de carnaval, entonces ese es un producto como de agradecimiento, una fiesta tradicional de carnaval con anatas, con flores, con todo lo que se siembra en el sector.

También siempre estamos manteniendo todas las costumbres que nos han dejado nuestros antepasados. Por ejemplo para recordarlos, las chullpa, siempre ellos han tenido ese respeto a las chullpa de saludar con un quelchi, eso justamente Axel lo ha mostrado, se da este quelchi como un aviso a las chullpa quienes también han sido poderosos, entonces de esta manera seguimos manteniendo estas tradiciones antiguas que nos han dejado. Evidentemente ha mermado en estos últimos años, un poco con la juventud, pero seguimos, nosotros tratando de mantener toda esta situación. Aparte de eso, como Justino ha hablado de nuestras riquezas en el sector, evidentemente que se está planificando ya a nivel comunal, ya no a nivel individual, entonces esa es la experiencia que estamos llevando. Ojalá esto ya lo tengamos muy pronto y como podemos poner en marcha ya la publicidad, esa es nuestra esperanza que sinceramente en nuestra región tenemos intactas todas estas riquezas. Entonces como Axel decía, antes ni arqueólogos, ni había tránsito de movilidades, nada. Era un lugar bastante desierto pero hoy en día está la riqueza como para vivir, pero lo peor es que no tenemos bastante ayuda, eso es lo que nos perjudica. $\mathrm{Y}$ eso sería para terminar una pequeña historia que les hago, muchas gracias.

\section{Discusión}

Mauricio Uribe: Realmente yo creo que lo que han hecho los colegas bolivianos es valiosísimo, en términos de que han sido unas de las pocas reflexiones teóricas desde la arqueología, para enfrentar la disciplina con una propuesta para las comunidades étnicas y lo que son los procesos de reconocimiento del lugar de las poblaciones étnicas. Aunque estas palabras tal vez suenen como no muy adecuadas, son importantísimas las reconstrucciones, las revaloraciones son importantes, especialmente las que vienen de los que están haciendo esta exploración.

Me parece que, sin duda, la experiencia de vivir en Bolivia, un país que tiene la mayor parte de su población indígena, que tienen civilizaciones tan importantes como la de Tiwanaku, que corresponde a una historia distinta a la que tiene Chile, es una historia muy distinta a la que se nos ha enseñado a desconocer nuestro pasado. Por lo tanto, de la misma manera en ambos casos, se ha utilizado la arqueología ideológicamente para construir los sistemas en los cuales se sustentan nuestras sociedades, y destacar que la arqueología, como otras ciencias, está siendo utilizada ideológicamente. Porque son parte de un proceso social en el cual se insertan los investigadores y las mismas comunidades, por tanto la historia de la arqueología es importante, es importante entenderla desde una perspectiva crítica, en una reflexión crítica y teórica, un poco también como lo manifestaba aquí Hans (Gundermann), para pensar que esta reflexión crítica ayude a no desconocer la diversidad cultural, que no nos homogeneicemos en términos o en grandes conceptos o conceptualizaciones étnicas que de repente van a ir en contra del mismo desarrollo indígena.

En ese sentido, destacar que los investigadores están insertos en un contexto social y tienen un rol en el proceso de la reconstrucción étnica, en la construcción de una identidad como son los procesos que se viven hoy día en Latinoamérica en general, por lo tanto, la experiencia boliviana tanto de los representantes indígenas como de los mismos estudiantes y profesionales bolivianos, es darse cuenta de la utilidad que tiene la disciplina y converger en algún diálogo, porque vemos que la arqueología es necesaria y tiene una actividad en la cual se va configurando una perspectiva, y una perspectiva que tal vez hay que darle a la arqueología en la Academia, en la Universidad.

Deberíamos pensar en cómo enseñar arqueología ahora, porque sabemos que es el momento en que reconozcamos que la arqueología es una ciencia necesaria, porque es un estudio de la construcción de la sociedad no solamente indígena, sino en la construcción de una sociedad compleja como es el caso de la sociedad boliviana que utilizó la arqueología en la construcción nacionalista, para construirse como nación, o en nuestro caso que se mal utilizó para ir desconociendo lo indígena y no reconocerlo hasta que se pudo obtener una Ley Indígena que reconociera a la diversidad étnica que hay en Chile. En ese sentido me parece fundamental la conciencia y la claridad que tienen los arqueólogos bolivianos y sus comunidades étnicas, o por lo menos las que han dado su experiencia acá, de no desconocer el rol y la importancia de la arqueología, de la antropología y ver en qué medida son utilizadas para la conveniencia de estos procesos. Esto de reconocer que la identidad étnica se construye a partir de un pasado, que el medio de acercarse a este pasado cuando se nos ha quitado, se nos ha negado, es la arqueología el medio metodológicamente adecuado, porque como hemos visto las críticas a la arqueología no son de que se digan mentiras, sino que de las prácticas, de cómo se ha hecho la arqueología.

La arqueología trata de encontrar una verdad o varias verdades y en ese sentido ajustarse a métodos que le puedan ser conocibles, discutibles, etc. En ese sentido el reconocimiento a esta disciplina, a la conciencia de recuperar ese pasado, de cómo hacerlo, hay que llevarlo también a la discusión final en el sentido de cómo queremos que sea la arqueología, no desconocerla, no evitarla, no negarla, o sea está, hay que utilizarla porque la sociedad se construye históricamente, el pasado queda depositado, está ahí, está presente, y en eso contribuimos todos; por 
lo tanto, finalmente, sinceramente decirles a los colegas bolivianos muchas gracias por este aporte y por esta reflexión teórica que realmente fue excelente. Muchas gracias.

Victoria Castro: Bueno, me sumo al agradecimiento y quisiera señalar algunos puntos concretos que unen una historia común sin negar esta unidad en la diversidad que es ese mundo que llamamos, a lo mejor no correctamente, los mundos andinos, pero que se insertan en un espacio y territorio geográfico de los Andes, definido por nuestra cordillera y nuestro mar Pacífico y la selva en aquellos países que la tienen y cuya historia colonial todavía no borraba esa unidad y ese flujo de relaciones, aunque después nos implantan en nuestras cabezas las fronteras geopolíticas de las repúblicas. Esto es un punto olvidado, pero un punto muy importante de tener presente a la hora de la necesidad del diálogo que debemos establecer, que necesitamos establecer con tanto las comunidades de la vertiente oriental andina en estos sectores, como con los profesionales de allá. No nos podemos olvidar que lo que era Chile era una Capitanía General, era algo menor dentro del gran Virreinato del Perú y de la Audiencia de Charcas que tocaba todos estos territorios de los que han hablado los colegas bolivianos, más Atacama la Alta y Atacama la Baja. En ese sentido es bueno reflexionar que durante siglos hubo fronteras blandas, flujo entre las poblaciones, hermandad entre las poblaciones, también desencuentro entre las poblaciones y no obstante eso hay una historia compartida, desde época prehispánica muy temprana hasta los tiempos coloniales. Pareciera que la república es uno de los efectos más fuertes, aun más que el proceso de evangelización y extirpación de idolatrías de los curas ibéricos.

Yo creo que hay tanto que aprender mutuamente; hay comunidades como esta, por ejemplo, quechuaparlantes, otras comunidades quechuaparlantes como la de Toconce, que reconocen a sus abuelos en un sentido genérico, puede ser el abuelo consanguíneo o puede ser un poco más atrás en el tiempo, con su origen en Alota, Soniquera, Quetena, que reconocen abuelos en Cochabamba, consanguíneos, y que, por lo tanto, hay una historia común y hay formas que pueden ser diferentes, pero otras complementarias para afrontar esta forma que nos toca vivir a todos en este año 2001. Entonces, yo creo que francamente es necesario que nunca más nos olvidemos de compartir estos espacios con nuestros hermanos bolivianos, cuzqueños, de la Quiaca, en fin, de este territorio surandino. Muchas gracias.

Ángel Bravo: Estuve anotando cosas interesantes, creo que anoche lo comentaba con don Carlos (Aldunate) en la mesa, en la cena, y que lo tocaron las ponencias de los colegas bolivianos, en el sentido, por ejemplo, lo que decía una ponencia que la historia universal se opone a la historia local. Hoy en día la reforma educativa chilena, especialmente en el área ciencias sociales, está privilegiando partir toda la secuencia histórica desde la comunidad, desde la historia local; entonces más que nunca toma importancia el hecho de que la arqueología se inserte en la práctica como decía Mauricio, porque acá la discusión sobre métodos y técnica está afuera de esto. Es decir, cómo la arqueología tiene que insertarse prácticamente en el desarrollo de las comunidades y en eso le cabe un papel fundamental en lo que viene.

Me llamaba la atención además, y también lo oí en una ponencia, sobre cómo el uso del pasado se utiliza para reafirmar la identidad. Bueno, recordemos el caso de Israel, precisamente ellos utilizan la arqueología como forma de entender su pasado y proyectarse como nación, de reafirmar allí en Medio Oriente todos sus enredos que tienen. Por otro lado, es importante saber cómo Bolivia tiene una gran población originaria que le han dado el carácter pluriétnico en la Constitución, cosa que acá en Chile nosotros no tenemos, el artículo uno de la
Constitución dice que nosotros somos una comunidad unicultural en consecuencia que la práctica está diciendo lo contrario, y mucho más todavía la Ley Indígena. Creo que también a modo de conclusión hay varios elementos acá.

La ponencia de Axel tocaba el hecho de que hay algunas comunidades, decía él, que están fuera de los circuitos turísticos, están fuera de estos intereses turísticos. En San Pedro de Atacama se está dando el caso de que, bueno hemos hablado de las comunidades que sí tienen acceso a los sitios arqueológicos, tienen acceso al turismo, pero hay otras comunidades, por ejemplo, la comunidad de Solor, me recuerdo en estos momentos, Larache, bueno está allí, pero que están reclamando, no es cierto, alguna participación dentro de esta oferta turística y creo yo que allí es necesario de alguna manera que cuando se planifique el turismo insertar estas comunidades ya sea elaborando un producto turístico o ya sea haciéndolos partícipes de sus beneficios económicos. Y bueno también el hecho que reclamaban los comuneros de estas comunidades vecinas. Yo recuerdo que hace dos semanas atrás en la Laguna Colorada, precisamente en Bolivia, concurrieron comunidades de San Pedro de Atacama para ver cómo hacen caso de esto, yo ya me estaba imaginando, cierto, como es posible integrar efectivamente en este circuito que va desde San Pedro a Uyuni a comunidades y meter por ejemplo el caso del Pukara (de Quitor), sitio que se ubica en el período Intermedio Tardío que es muy significativo por lo que se está haciendo en la arqueología o en los circuitos arqueológicos de San Pedro.

Donald Jackson: En lo personal, no me gusta pensar en una arqueología utilitarista. Pienso también que los usos de la arqueología no son asépticos, son también bastantes complejos. $\mathrm{La}$ arqueología produce conocimiento y el conocimiento se puede usar de distinta forma y ahí entramos en un plano valórico. Estoy pensando en un ejemplo lejano al de nosotros, es el ejemplo de la arqueología oficial mexicana. En la arqueología oficial mexicana básicamente se planteó la excavación principalmente de los grandes templos mexicas. ¿Y por qué eso? Para reivindicar una identidad, pero resulta que esa identidad era una sociedad estatal, una sociedad explotadora de las comunidades que tenían que tributar forzosamente al estado mexica. Entonces, ojo, el conocimiento arqueológico como cualquier otro conocimiento tienen usos y usos que implican valorizaciones distintas, entonces tenemos que tener cuidado en esos puntos. Ese es mi comentario.

Ulises Cárdenas (arquéologo, Proyecto Ollagüe): Yo quería agradecerles la gentileza a los hermanos bolivianos y algunos concurrentes el hecho de haber llegado a Ollagüe por sus propios medios ya que nosotros no auspiciamos su traslado desde sus lugares de origen. También considero que Bolivia está a diez mil años luz, en una metáfora, en relación a Chile en temas como los que han sido tratados en la relación de comunidades indígenas con los arqueólogos. En ese contexto yo creo que el primer grupo de Chile que enfatizó la necesidad de participar activamente con las comunidades en donde se realizaban investigaciones lo constituyó el grupo Toconce que acá los dos coordinadores Carlos Aldunate y doña Victoria Castro, junto a José Berenguer, los forjadores desde que iniciaron sus investigaciones, dieron este cambio de visión a la arqueología que se estaba desarrollando.

Por otra parte también quiero señalar en relación a lo que hablaba Axel Nielsen, esa experiencia podría ser tomada como un paradigma para la zona de San Pedro de Atacama donde se están desarrollando y se están implementando rutas turísticas y en donde, positivamente, ahora recién se está tomando en cuenta la participación de las comunidades indígenas. Finalmente darles las gracias de nuevo a los colegas bolivianos por haber hecho el sacrificio y proponer en otras jornadas el desarrollo de 
talleres binacionales, así como se hizo el taller de Costa-Selva en Argentina, hacer un taller de altiplano. Muchas gracias.

Patricia Ayala: Bueno yo quería presentar la idea en este encuentro de invitar a los colegas bolivianos y argentinos a contar su experiencia, fue precisamente la de enriquecer este evento ya que las experiencias que nos cuentan de lo que está pasando en Bolivia desde el punto de vista teórico y también desde un punto de vista práctico -así como, quizás más adelante, podríamos escuchar la experiencia de Axel sobre la postura argentina- van a enriquecer no sólo a nosotros como profesionales, sino sobre todo a las comunidades. También para que vean cómo en otros ámbitos se están trabajando temáticas como las que estamos tratando en este encuentro.

Sin duda, sobre lo que dice Donald, que la arqueología puede tener distintos usos. Quería hacer la acotación de que existimos algunos investigadores que hemos tenido como razón, o como parte de nuestro desarrollo profesional, la necesidad de encontrar una utilidad más social a esta disciplina. Yo muchas veces me he enfrentado a artículos e informes arqueológicos o frente al mismo trabajo del arqueólogo, y preguntarme de qué sirve en concreto, cuál es mi aporte en corto plazo a la sociedad en general con el trabajo que estoy realizando. En este sentido, yo me adhiero mucho a los planteamientos de los colegas bolivianos, tanto como a otros de los colegas chilenos, ya que para mí es fundamental verle esta utilidad a la arqueología y entiendo y respeto completamente las posiciones de otros investigadores de las cuales en su perspectiva no vayan directamente a buscarle una función social a nuestra carrera.

Creo también que es muy relevante considerar si la arqueología en estos momentos está difundiendo su conocimiento a las comunidades, también es importante que difunda su saber hacia otras disciplinas como por ejemplo la educación. O sea, en qué medida nosotros como arqueólogos podemos apoyar y apostar en este proyecto educativo o en proyectos de otro tipo que se escapan de mi memoria en estos momentos, pero creo que nosotros como arqueólogos, fundamentalmente somos cientistas sociales y desde mi perspectiva tenemos que tener un rol que sea más activo. Les agradezco mucho que hayan llegado a mis colegas, alumnos y también a los representantes de los Lipes. Muchas gracias por haber venido.

Carlos Aguilar: Yo quería referirme, al haber escuchado esta forma, otra forma quizás de hacer arqueología, otro trabajo, sin duda de que todos los trabajos en alguna medida tienen aportes; efectivamente, fuimos a Quetena algunos dirigentes del pueblo de San Pedro de Atacama y los demás pueblos ayllus, en función de un acercamiento entre el trabajo que se está haciendo en Chile con la CONAF y en Bolivia con las áreas silvestres. Y lo hemos hecho no solamente con el interés económico como se ve en un principio, sino más bien en cómo regulamos el turismo, y creo que ahí hay que ponerle bastante énfasis sobre todo las comunidades con el trabajo turístico, si no los invito a conocer San Pedro de Atacama no más. Y no solamente las consecuencias físicas que se ven, o las materiales, sino otras muchas. Ya que lo que estamos ofreciendo hoy día, mañana no lo vamos a poder ofrecer, ni siquiera lo vamos a poder disfrutar y el aporte que hagamos en el futuro para nuestra, así decirlo, sociedad o nuestra forma de vida que tenemos, creo que los aportes no van a ser muy significativos. Entonces, creo que rescatar parte de este trabajo arqueológico, antropológico, bueno y todas las disciplinas que tienen que ver con los trabajos antiguos o con la vida antigua; y ver cómo hacemos para hacer un trabajo para la vida futura también, o sea para tratar de generar una vida en que podamos ser un poco más, o podamos disfrutar de esta libertad, de la libertad esa que tenemos.

Así es que, bueno, este acercamiento ya lo estamos haciendo dentro de las comunidades, pero no piensen que es sola- mente por ese valor económico, es también con el valor de regular algunas cosas y que creo que con toda esta tremenda máquina no es fácil regularlo. Entonces por eso también, al venir acá, es importante, como hemos dicho ayer, la importancia de poder generar un trabajo distinto con quienes trabajan en esta área. Eso era, gracias.

Donald Jackson: Patricia, yo te quería dar a ti una respuesta en lo personal. Yo me eduqué en una escuela donde se hacía énfasis en una arqueología social y yo creo que la arqueología tiene que tener un sentido social. Pero yo apunto a que, como científicos sociales tengamos nuestras antenitas muy atentas a qué es lo que se hace, no olvidemos que el estado nazista utilizó a los arqueólogos, y muchas dictaduras latinoamericanas han reivindicado símbolos indígenas para legitimarse. Entonces en ese sentido los científicos sociales tenemos que ser tremendamente responsables, cuidadosos con nuestras proposiciones. Aquí no se pueden vender recetas porque hoy en día podemos plantear algo que a mediano plazo puede ser muy rentable económicamente, pero en un plazo más prolongado a lo mejor destruimos una sociedad.

Roxana Seguel: Yo quería felicitar a los colegas bolivianos el trabajo que han hecho porque yo creo que nos han dejado bien impresionados, sobre todo por lo que decía Mauricio, la profundidad de su reflexión y cómo eso se ha transformado en una praxis en su quehacer profesional. Y quería referirme un poco a lo que decía Carlos (Aguilar) y también lo que señalaba Donald recientemente. Yo creo que una de las razones por las cuales estamos aquí es justamente para presentar cuidados sobre lo que ustedes están diciendo. O sea, yo creo que nadie quiere, sobre todo ustedes, tener un nuevo San Pedro de Atacama, o lo que contaba Axel sobre la comunidad que estaba cerca del área en que ustedes estaban trabajando. Tampoco tenemos que tenerle miedo a hacer un uso económico de nuestro patrimonio, porque finalmente vivimos en una sociedad de mercado donde los bienes se transan y el tema que no tenemos que tenerle miedo a eso, el tema es el cómo. Y yo creo que Donald puso ahí un punto de atención, sobre la manera cómo se está haciendo. Aquí quiero tomar una frase que dijo una colega boliviana, que lo mejor es trabajar en el diálogo horizontal, o sea el tema de la información, que se genera, sea una información venida de la tradición oral, sea una información científica que se materialice a través de la escritura, la forma que tenemos de algún modo de avanzar en el trabajo tienen que ver con el diálogo horizontal. El diálogo horizontal que yo creo que estamos desarrollando en esta reunión y que tiene que ser planificado y organizado.

Lo que pasó con comunidades o localidades no necesariamente indígenas con respecto al turismo donde han sido avasalladas sus formas de vida y donde llega la industria turística, porque aquí no estamos hablando de pequeños grupos, son transnacionales turísticas o industrias turísticas donde muchas veces la sociedad o la localidad no puede tener una relación de igualdad. La manera de fortalecernos a quienes nos interesa esta área es justamente a través de este diálogo horizontal y el aprender a trabajar juntos y el aprender a trabajar juntos significa el mirar, como decía Carlos Aguilar, a largo plazo, o sea el poder mirar hacia mañana y que todavía mañana y nuestros hijos también tengan un mañana mejor. Nosotros somos responsables del mundo que vamos a entregar a futuro y el mundo nos lo jugamos hoy, lo que pase hoy va a ser el resultado de que nuestros hijos tengan el día mañana, yo creo que eso es importante, de hacer un compromiso de trabajo de diálogo horizontal de planificación y de mirada no inmediatista; creo que fue Cristián el que dijo que no le importaba la cosa de la burocracia, a veces la burocracia es lenta pero segura. Creo que fue Axel o uno de los colegas bolivianos; la burocracia es lenta pero segura, bueno ocupemos los instrumentos legales que te- 
nemos, aun cuando sea una burocracia lenta pero segura para hacer un trabajo de mejor calidad del cual no nos arrepintamos mañana y nuestros hijos nos saquen en cara de cómo les estamos entregando finalmente el mundo a que ellos les va tocar vivir, por el cual se van a responsabilizar.

Patricia Cepeda (Lic. en estética, Universidad Católica): Bueno, yo tuve la oportunidad y la suerte de crecer en el trópico, Venezuela. Cuando llegué a Chile me encontré con una sociedad altamente compartimentada, diferente a la sociedad que yo había conocido en Venezuela, que era una sociedad que se basaba en la valoración de lo popular, de la raíz indígena, de la raíz africana y, digamos, del manejo de toda esta modernidad que había llegado. Entonces al llegar a Chile, la verdad es que para mí fue un choque encontrarse con gente que se movía en su circulo, así como burbuja, cada uno. Entonces habría que pensar que en el fondo, como política nacional, en Chile todos sufrimos, por así decirlo, estímulos, que no sé muy bien de dónde vengan, pueden ser de las telenovelas, de la educación, pueden ser de los militares, pueden ser de nosotros mismos, que nos llevan a separarnos como grupos diferentes. Eso digamos como experiencia, comparándolo con otros países, como en el caso de Venezuela donde tuve que estar viviendo. Entonces en este sentido creo que hay algo como que es superior a todo lo que nosotros defendemos como pequeñitas cosas, arqueólogos, comunidades -no digo pequeñitas en términos peyorativos, sino que pequeños núcleos que son-que todos sufrimos del mismo mal, que es el mal de la compartimentación que está en Chile, de la separación entre los grupos.

Yo creo que habría que reflexionar un poco eso, que por ejemplo oyendo a la gente que venía de Bolivia y otros países que también han sufrido dictaduras, por qué en esos países con dictadura han podido sacar adelante igual un intercambio entre las diferencias, o sea hay algo en Chile, no sé que será, verdad, que un poco favorece, la separación entre los grupos. Porque en Venezuela yo he visto obras maravillosas en las cuales gentes muy diversas está colaborando, lugares, pensando en el Museo de San Pedro de Atacama, en general los espacios públicos la gente los asume y los usa como propios, y por qué aquí no, por qué aquí hay esa sensación de tanto permiso, verdad, o tanta carta o tanta burocracia, o para qué, para poner barreras. Entonces a quién le interesan las barreras, a lo mejor a todos nosotros y hay que preguntarse cada uno cuál es su punto de vista, qué es lo que tanto quiero yo defender y de quién, porque quizás ni siquiera nos conocemos bien. Eso nada más.

José Capriles (arqueólogo, Universidad Mayor de San Andrés, Bolivia): Yo quería también a nombre de mis compañeros, colegas bolivianos agradecer a Patricia [Ayala], a sus colegas y a las comunidades locales por la organización y el habernos invitado a participar de este evento. Nosotros en Bolivia teníamos la sensación que iba a ser un encuentro un poco más pequeño, más modesto; la verdad nos sorprendió mucho la cantidad de gente que esta aquí, dirigentes de otras comunidades y la verdad estamos sorprendidos de Chile. Tanto avance en Chile en arqueología y nosotros nos sentimos un poco menos que su arqueología, porque recién estamos empezando, pero es sorprendente que todavía este tipo de temas recién se estén empezando a reflexionar. Obviamente hay un proceso histórico, no es la primera vez que se están tocando estos temas aquí en Chile, pero de todas maneras en Bolivia esto ha sido más incentivado por las comunidades. Los arqueólogos, la mayoría de nosotros respondemos a las demandas que tienen ellos, los dirigentes locales, ahí son muy fuertes, en el mismo Tiwanaku actualmente, desde el año pasado ha habido una toma en las ruinas bastante simbólica, todos los ingresos que ahora llegan a Tiwanaku, el principal sitio turístico-arqueológico que hay en Bolivia ahora va directamente a las comunidades como iniciativa suya
Entonces consideramos que podemos entablar un diálogo un poco más provechoso a través de talleres con los colegas chilenos entonces a ver si nos enseñan un poco más de metodología, técnicas de investigación, nosotros podemos aportarles un poco ese relacionamiento con la comunidad que ya está bastante bien establecido, ya son varios años que se viene trabajando con las comunidades los resultados son alentadores en ese sentido. Queremos nuevamente agradecer a Patricia por la invitación. Gracias.

Carola Condarco: Bueno, yo hablo muy rápido a veces me olvido cosas. Quería agradecer también a los organizadores y a la oportunidad de darnos de hablar con renombrados arqueólogos, para mí especialmente es un honor estar aquí.

Yo me iba al trabajo con la comunidad, ya hemos realizado un texto informativo para los niños, los núcleos escolares de la zona, los profesores; hay un orfanato en la zona de Paria, dan como tarea ir a recoger, prácticamente a huaquear cosas para ellos, entonces los niños van, huaquean tranquilos y llevan su tarea a los profesores. Entonces estamos empezando una campaña para crear un comité de antropólogos; en Oruro no hay arqueología yo prácticamente soy una de las orureñas que está trabajando allá, hay muchos paceños, mucha gente de otras partes que está trabajando allá y yo quisiera crear un comité para ir a hablar a comunidades, porque en arqueología en Bolivia sí se está trabajando con las comunidades. En Pisiga fuimos con Patricia Ayala a visitar, ellos tienen muchos restos de tumbas, ellos quieren hacer un museo y esto está muy de moda ahora hacer museos regionales y el gobierno y las autoridades tiran por ese lado: "ya, vayan, lleven turistas tienen platas, tienen ingresos", pero ojo, en Bolivia es poca la arqueología que se está llevando a cabo, hay muchas ideas, muchos proyectos pero no hay plata, no hay financiamiento. Lo que yo voy a plantear es que, primero se deben hacer investigaciones arqueológicas, manejar un turismo planificado, crear museos regionales y no todos los yacimientos arqueológicos pueden ser visitados, no turismo masivo, hay que tener mucho cuidado. Nos falta también en Bolivia la conservación, preservación. Se están haciendo cosas como las chullpa que refaccionaron, ahora están echando ojo a las chullpa pintadas. Hay que tener cuidado, estar prestos a que las autoridades no hagan estupideces.

También es muy importante el trabajo con las comunidades, es muy lindo lo que nos trae Axel, es una propuesta muy linda, me ha encantado y también los comuneros que lo acompañan. Es muy rica la tradición oral y las historias. Muchos son los de los pueblos los que nos guían a los lugares arqueológicos, a los pukara, a los sitios y a mí me da un poquito de rabia porque cuando uno pregunta qué es eso, "chullpa", todo es chullpa. Es muy rica la tradición, la historia del sol, las chullpa, las casitas, las tumbas que para ellos son casas en muchos lados. Pero yo creo que también tenemos la obligación, como arqueólogos, de enseñar, ser profesores en las comunidades, ir a los núcleos escolares; muchas veces no se habla de esto, se lleva una historia lineal, no se pueden cambiar los libros, se sigue investigando, siguen encontrando cosas nuevas y no se toca esto, los historiadores muchas veces en muchos casos los textos son iguales, repetitivos.

Nosotros dimos un curso allá con proyector multimedia para enseñarles esto, qué nos dice un fragmento, quiénes estaban antes, quiénes estaban después y que éstas chullpa, que ellos conocen, también son del período Formativo, cuántos años estaban y el desarrollo del hombre en el lugar. A mí me parece importante que sepan los arqueólogos somos los que ponemos tiempo y espacio, pero ellos tienen que aparte de conocer su tradición oral, tienen que también conocer la historia y el suceso que ha sufrido cada lugar y eso es lo que nosotros hemos hecho y hemos trabajado con las comunidades. Muchas gracias. 
Roberto Martínez: Sabes que yo quisiera hacer un comentario respecto al uso del conocimiento obtenido por la arqueología en relación a esta alerta que deben tener los profesionales en el área, el tratar de no caer en este tipo de juegos políticos, hacer un uso político de esto y quisiera ampliar esta alerta no solamente a los científicos, sino que también esta alerta debe llegar a los representantes de las comunidades originarias, porque no solamente son las dictaduras las que tratan de aprovecharse del discurso de la necesidad de tener una representación étnica en el quehacer nacional, sino que incluso los así llamados regímenes democráticos utilizan, por no decir manosean, los intereses de estas comunidades en su propio beneficio, por lo tanto, yo creo que es algo que debe mantenerse en alerta. Gracias.

\section{Mesa Redonda Final}

Carlos Aldunate: En nombre de esta mesa queremos dar en primer lugar, un afectuoso agradecimiento a la Comunidad Quechua de Ollagüe, quien nos abrió las puestas de su pueblo y nos atendió con gran solicitud. Gracias también a los organizadores de esta reunión que tuvieron esta novedosa idea de reunir a las comunidades étnicas con los investigadores, cuyos resultados excedieron nuestras mejores expectativas.

La conclusión más importante de esta reunión, sin duda, está relacionada con el exitoso compartir de experiencias, dudas, preocupaciones, entre las comunidades y los investigadores. Esta reunión ha hecho posible que nos comuniquemos positivamente y cara a cara, cosa que con la lejanía en que vivimos es casi imposible, y por esto mismo, esta situación no puede ser un evento único y será preocupación especial de esta mesa el tratar de repetir este evento y convertirlo en una reunión periódica que se podría realizar eventualmente en diferentes localidades, creemos que un plazo prudente para que estas cosas sean posibles y no sean totalmente utópicas sería alrededor de tres años.

Se ha debatido en esta reunión acerca de la relación entre patrimonio cultural y turismo, se han visto los efectos positivos y negativos para las comunidades. En este contexto algunos de los representes de las comunidades han solicitado apoyo de los arqueólogos para contextualizar los sitios arqueológicos que tienen en los sectores que manejan. Se han debatido y se han expuesto dificultades de las comunidades con diversas autoridades e instituciones nacionales tales como el Consejo de Monumentos Nacionales, CONAF, etc., y algunos museos regionales. Hay sin duda problemas de comunicación, hay falta de información y algunos de ellos son bastante fáciles de solucionar y ya hemos conversado acerca de este punto. Por su especial relevancia y gravedad queremos resaltar la posible declaración de parque nacional de tierras pertenecientes a la comunidad de Caspana, proceso que se ha hecho hasta ahora sin consultar a los comuneros y que podría limitar sus derechos en las fuentes de agua, sitios ceremoniales, etc. Se ha decidido comunicar a CONAF esta preocupación y urgirles un pronto contacto con la comunidad para aclarar estos problemas.

Una especial felicitación de la mesa para el proyecto de educación bilingüe que se está desarrollando en la comunidad de Ollagüe, hemos quedado gratamente impresionados con esta experiencia y con la vocación de sus gestores que es crucial para su éxito, y que ha contado con el apoyo decisivo del equipo de antropología y de arqueología que los ha asesorado.

Otra mención especial para resaltar la presencia de los miembros de comunidades e investigadores de Bolivia, que nos han mostrado un verdadero modelo de relación entre la arqueología y las comunidades étnicas, en la cual se ve enriquecida tanto la comunidad como la interpretación arqueológica.

La mesa quiere interpretar también ante las autoridades pertinentes la preocupación de las comunidades indígenas y las comunidades científicas para la pronta suscripción por parte del Estado de Chile de la Declaración de la Organización Internacional del Trabajo Sobre Pueblos Indígenas y Tribales, sobre la pronta suscripción por el Gobierno de Chile del Convenio sobre Protección y Tráfico Ilícito de Bienes Culturales de la UNESCO y también el apoyo de esta mesa y de esta reunión a la proposición de declarar Área de Desarrollo Indígena a las comunidades del Alto Loa tal como fue ya declarada en Atacama la Grande.

Pensamos estimular más todavía a CONADI a continuar apoyando estas reuniones y le sugerimos establecer convenios con universidades chilenas para que prácticas profesionales o memorias de título de estudiantes de ciencias sociales se orienten hacia los problemas que interesan a los pueblos indígenas del país.

Hay otras proposiciones bastante más específicas y concretas. Hemos conversado con la mayoría de los arqueólogos y antropólogos que estaban aquí presentes en esta reunión, los que están dispuestos a preparar material escrito a las comunidades, especialmente hecho para que ellos lo puedan utilizar de la manera que les parezca, ya sea para turismo, ya sea para información muy personal, propia de los pueblos, para su proceso étnico etcétera, o lo que ellos decidan. Estos documentos se podrían entregar a las comunidades a las que se les ofrecería además jornadas de capacitación al respecto. Esta actividad sin embargo no podría ser en un plazo corto, porque serán necesarios algunos años para preparar estos materiales y que lleguen buenos resultados. Probablemente no se necesitarán más de dos o tres años, se incluiría dentro de esta cartilla y capacitación un manual para que las comunidades conozcan elementos administrativos y legales, para que no se produzcan malos entendidos respecto de la administración de los monumentos nacionales y el patrimonio cultural que se ha entregado en custodia a las comunidades, la normativa legal, la manera de acceder a las instituciones, Consejo de Monumentos Nacionales, a museos y otras autoridades. También se incluiría un sistema de contacto entre las comunidades y los sistemas académicos, los profesionales de ciencias sociales que trabajan en las comunidades.

Se ha expuesto que hay una preocupación de las comunidades respecto de los antropólogos, arqueólogos o sociólogos que los visitan y pensamos que podemos conversar con las sociedades científicas y las sociedades profesionales para que ellas presenten a los profesionales ante las comunidades, a los profesionales que van a actuar dentro de ellas y así exista una especie de acreditación de estos profesionales ante las comunidades. Toda esta proposición específica naturalmente necesita de un financiamiento y pensamos que podemos gestionar juntos con las comunidades un financiamiento para estas actividades ante fundaciones, la Fundación Andes, los mismos que cooperaron en esta reunión, CONADI, etc. y las comunidades también podrían aportar financiamiento tal como lo hizo la comunidad quechua dándonos las facilidades de sus instalaciones, etc. y poniendo a nuestra disposición todas las comodidades y el servicio que la comunidad quechua nos dio en esta oportunidad, podría ser como un pequeño modelo a repetir.

Otro interesante aporte a la relación fructífera entre comunidades y científicos, será la realización de las Escuelas Andinas el próximo año 2002 en el Instituto de Investigaciones Arqueológicas y Museo R. P. Gustavo Le Paige de San Pedro de Atacama que cuenta con el apoyo de CONADI, en esta oportunidad guías y administradores de sitios arqueológicos de las comunidades podrán tener acceso a una capacitación sobre el patrimonio que administran; este curso durará un año y su cupo será de 20 a 25 personas.

Estas son las conclusiones de esta reunión, pero como no podemos tener la pretensión de haber englobado y de haber dicho y resumido todo lo que aquí se dijo que obviamente fue 
mucho más rico que esto, pensamos que los miembros de esta reunión pueden hacer llegar a la mesa, pero no más allá que dentro de este día, a través de los organizadores, proposiciones concretas y por escrito por favor para que sean incorporadas a estas conclusiones. Ahora pensaba yo dar la palabra a los organizadores de este evento porque este evento forma parte, no sé si todos ustedes lo saben, pero forma parte de un proyecto de investigación que está a cargo de la Patricia, de Ulises y de Sergio, entonces ellos son los organizadores y pensaba darles la palabra ahora a ellos.

Patricia Ayala: Bueno, como les había mencionado en otras ocasiones este proyecto es un proyecto financiado por Fundación Andes y la Municipalidad de Ollagüe y fue patrocinado específicamente por la CONADI. El proyecto que nosotros realizamos está en su etapa final, esta es la tercera etapa y nosotros ya efectuamos otras dos, una de habilitación museográfica y otra de talleres de capacitación, cuyo fin fue específicamente buscar el mecanismo por el cual nosotros como investigadores pudiéramos acceder a un vínculo más cercano con la Comunidad Quechua de Ollagüe, y me atrevería a decir que después de estas diferentes etapas sí hemos logrado ese objetivo ya que hemos estado mucho más cerca de la comunidad en diferentes aspectos, la misma comunidad ha participado también de este encuentro de distintas maneras, ustedes lo han visto.

Yo quería decirles que la realización de este proyecto fue una iniciativa que se gestó desde el año pasado; los gestores fueron Ulises Cárdenas con Sergio Avendaño y me invitaron a participar en el proyecto y posteriormente conjuntamente presentamos el proyecto a Fundación Andes y fue ganado y la realización de todo este proyecto a lo largo de este año creemos que ha sido beneficiosa, tanto para la comunidad como para nosotros, porque nosotros hemos aprendido enormemente en esta experiencia, particularmente mi persona. He aprendido mucho en este proyecto, como en todos los proyectos, ha tenido momentos de mucha relevancia, momentos también difíciles, momentos de mucha intensidad en el trabajo mismo, pero toda la intención nuestra como investigadores ha sido generar este espacio de mayor relación con la comunidad. También el tener este encuentro para nosotros ha sido muy relevante, porque queríamos que la comunidad de Ollagüe viera como otras comunidades están trabajando el tema del patrimonio cultural y también que pudieran venir otras gentes de otras comunidades, para insertar a Ollagüe en la discusión no sólo de la investigación arqueológica en general, sino también de otros ámbitos del conocimiento.

Queremos resaltar la importancia que han tenido los distintos conocimientos que aquí se han debatido y decir que nosotros la intención de que con este proyecto se haya iniciado una línea de trabajo acá en Ollagüe ya iniciada hace muchos años por Leandro Bravo, pero que recién ahora se está retomando después de el fallecimiento de él y que esperamos que este proyecto a la larga también tenga otro tipo de perspectivas, como proyectos de investigación. Hay varios sitios arqueológicos en la región, también otro tipo de proyectos que podrían seguir la misma línea de trabajo y en lo cual nos sentimos muy contentos es que la municipalidad en todo momento ha apoyado los trabajos e iniciativas de este equipo de trabajo y también queremos resaltar que la comunidad quechua también ha hecho llegar su interés de que también haya una continuidad en el trabajo.

Finalmente quiero decirles que la municipalidad de Ollagüe está haciendo una propuesta que se tienen que evaluar, que el próximo año se pueda generar otro encuentro acá, pero es algo que tenemos que discutir a nivel más macro, general. Igual queremos agradecer mucho la disponibilidad de la municipalidad para generar este tipo de encuentro, y también quiero agradecer mucho a la CONADI, a doña Liliana Cortés que nos ha apoyado muchísimo en la realización de este encuentro en esta etapa final y sin su apoyo habría sido mucho más dificultoso para nosotros haber llegado a buen término con todo esto. Bueno, eso en general, y nosotros tres, Ulises, Sergio y mi persona quieren agradecerles de sobremanera porque esto ha sido una experiencia muy, muy importante.

Axel Nielsen (arqueólogo, Instituto Tilcara): En Argentina, a partir de 1994 se reformó la Constitución argentina y se aceptó la preexistencia cultural y territorial de las comunidades indígenas, y en julio de este año (2001) la Argentina adhirió al Convenio 169 de la OIT, o sea, que ya está todo el macro marco legal para implementar una gestión, o una cogestión, con las comunidades indígenas el patrimonio cultural arqueológico y tangible. A partir de esto, en la Argentina hasta ahora el patrimonio arqueológico pertenece a las provincias, las 22 provincias argentinas tienen su constitución, es un país federal y tiene sus propias legislaciones en relación al patrimonio. A partir de esta reforma macro de la Constitución y la adhesión al convenio de la OIT, entonces todas estas constituciones, todas estas legislaciones provinciales pasan a ser inconstitucionales técnicamente; entonces a partir de 1994, yo vivo en la quebrada de Humahuaca, en Tilcara, en territorio indígena, y cuando yo llegue ahí el año 1992 a vivir casi nadie, no habían comunidades indígenas.

Hoy en día, en Jujuy solamente, hay 160 comunidades indígenas con reconocimiento jurídico; alrededor del año 1995 1996, dos años después de la constitución, todos se declararon como collas, que fue la primera bandera de identidad que tomaron como miembros del collasuyu, esta era la reivindicación y poco a poco, en los últimos cinco años se han ido desgajando en identidades étnicas más locales, entonces ahora hay umahuacos, ocloyas, casavindos, cochinocas. Otros son comunidad indígena San José, por ejemplo, entonces no tiene una adhesión a una etnicidad concreta. Pero en este proceso obviamente la información arqueológica es una de las principales fuentes de información para muchas de estas expresiones, en parte porque esto fue institucionalmente como acelerado, porque había fechas en las cuales tenían que inscribirse para poder constituirse como comunidades indígenas y el móvil para hacer esto era la posibilidad de acceder a las tierras. Se están entregando tierras en forma comunal de lo que eran tierras fiscales y tierras de antiguas haciendas se están entregando en propiedad comunal a comunidades indígenas. Estos eran un poco los móviles por los que las comunidades se organizaron.

A partir de esto empezó un cuestionamiento muy fuerte, que casi explotó en los últimos años, a la acción de los arqueólogos que trabajamos en la región y hasta ahora solamente se expresa en la provincia de Jujuy reclamando que nosotros trabajamos de acuerdo a la legislación que existe. Es el poder ejecutivo provincial que nos da los permisos, previa evaluación de un proyecto para realizar la investigación. Entonces empiezan a cuestionar la legitimidad de la Constitución Provincial, necesitamos la autorización oficial de las comunidades que es el planteamiento, es como que hay un marco legal que está en estado de flujo. Para resolver esto, entonces, hace dos meses creamos una comisión mixta con cinco arqueólogos y cinco representantes del foro de comunidades indígenas de Jujuy, que no es un organismo vinculante sino un foro, es un lugar a donde concurre cada comunidad que es autónoma, independiente y discute problemas, entonces estamos sentados y hemos hecho una comisión para reformar la legislación de arqueología en la provincia de Jujuy.

Lo que surgió primero en esto, mucho de los reclamos y de conceptos que se han contrastado y expuesto en esta reunión han surgido en los dos meses en esta comisión. O sea, hay muchos paralelismos, realmente, entre lo que está pasando en Argentina y lo que yo veo que está pasando aquí; por eso surge la 
idea de que tal vez sería importante aunar experiencias de los dos lados. Es interesante que en un principio estas reuniones giraban en torno a reclamos como este, por ejemplo, no se lleven las cosas, devuélvanos la información en un lenguaje que sea aceptable y que sea accesible y que lo podamos entender; estos son los primeros reclamos. Otro es solicitar ayuda para la puesta en valor de los sitios en función del turismo. Una y otra vez uno escucha esto en las comunidades.

En una segunda instancia paso a un cuestionamiento mucho más profundo, cuál es la legitimidad de los arqueólogos de investigar el pasado sin la autorización de las comunidades indígenas y esto es la clave de la legislación. En principio lo que manejamos era una idea de cogestión, crear un organismo con representantes de la universidad y de las comunidades indígenas que conjuntamente evaluaran todo proyecto y lo autorizaran. Esto es una idea de lo que queremos implementar en la ley. Ahora, qué peso tiene la opinión de esta comisión, por ejemplo si las comunidades indígenas se oponen, los arqueólogos de todos modos pueden trabajar, o no. Acá hay unos sutiles problemas legales pero que van a decidir cómo va a ser la arqueología en las próximas décadas, al menos en la Argentina. Creo que ustedes están transitando un poco hacia el mismo punto, a la misma reflexión.

En alguna medida después empezamos con un discurso un poco fundamentalista y poco a poco nos hemos ido acercando. Actualmente la base de esta comisión es respetar una interculturalidad básica, reconocer que existen dos perspectivas que son legítimas, una perspectiva de los pueblos originarios que se vinculan con este patrimonio como descendientes directos de su historia, y una perspectiva científica que representa al resto de la sociedad que también construye su entendimiento de la historia, del universo, de su identidad, pero no como descendientes directos de este patrimonio. Son dos perspectivas legítimas, una la representamos los arqueólogos, como minúsculo sector de la sociedad, sino en tanto que la sociedad nos contrata, nos da trabajo y nos financia para llevar adelante este tipo de preguntas, estas inquietudes de la sociedad mayor. Entonces un poco esta es la base de trabajo.

Y lo segundo que surgió es que pronto empezamos a darnos cuenta que en realidad tanto indígenas como arqueólogos somos un minúsculo sector de la sociedad frente al resto de la sociedad que en el fondo no le importa nuestro patrimonio muchas veces. Esto surgió en relación a las obras de ampliación del paso a Jama que no tenía ningún tipo de impacto arqueológico, sabiendo que hay sitios que están siendo destruidos por esta obra. Entonces en un momento en estas profundas discusiones sobre lo dialógico y las diferencias culturales, dijimos bueno, mientras estamos entonces charlando allá afuera están destruyendo el patrimonio y nosotros somos los únicos que lo vamos a defender. Entonces ahí hubo una cosa catártica, hicimos una nota y paramos la obra al paso Jama. Entonces fuimos, hicimos un diagnóstico juntos y ahora implementamos para hacer los rescates equipos mixtos de arqueólogos con personas de las comunidades, con la idea de crear una reserva de técnicos arqueológicos en todas las comunidades que en el futuro participen en toda intervención sobre el patrimonio arqueológico en comunidades. Dar la formación técnica para que todos los equipos sean mixtos, compartan ellos, entiendan de dónde sale nuestro conocimiento, y nosotros podamos familiarizarnos con las formas y los valores que ellos ven en ese patrimonio. Bueno y a partir de esto entonces estamos como tomando cartas en el asunto, todavía no hemos podido hacer la legislación, todavía no hemos firmado el acta de matrimonio, pero estamos como en un sirviñacu, trabajando juntos y haciendo cosas desde el entendimiento cara a cara y de palabra y esto ha sido muy fuerte porque nos ha permitido proporcionar las pequeñas diferencias que tenemos entre nosotros con relación a lo que está sucediendo en el mundo con el patrimonio y que si noso- tros perdemos demasiado tiempo en estas sutilezas podemos llegar a perder todo tanto para nosotros como para ustedes. Creemos que es la base para una alianza.

Entonces, la propuesta concreta era que tal vez, habría que decidir cuándo se podría hacer una próxima reunión en Tilcara, por ejemplo, no sé si con todos pero con toda la gente que pudiera acudir, tanto de estas comunidades indígenas de Chile como arqueólogos de Chile, que podamos discutir estas ideas allá y en terreno también ver un poco los problemas en común y diferentes, por supuesto también con la gente de Bolivia.

Liliana Cortez (Jefa de Oficina San Pedro de Atacama, Corporación Nacional de Desarrollo Indígena): Bueno, yo lo que quiero decir hoy día es un poco reflexionar con el encuentro que hubo en Cupo, un encuentro muy pequeño donde se tocaron y discutieron estos temas. Qué rico hoy día ver cómo esto crece; yo les digo que estos momentos de reflexión y de encuentro entre profesionales, entre académicos, en que participan instituciones y en que estén las comunidades, digamos, es tremendamente enriquecedor para todos, yo les digo uno aprende mucho, de hecho hoy día hemos escuchado a la gente de Bolivia, a la persona que acaba de hablar que vienen de Argentina y que ha hecho una invitación. Yo creo que es rico ver cómo crece, pero creo una sola preocupación, yo creo que es importante cómo se van desarrollando las cosas con tanta velocidad en todos los ámbitos es importante, a lo mejor ir concretando y comprometiendo un poco esto para la mesa, me preocupa, yo sé que están las conclusiones, los acuerdos, pero me gustaría eso un poco, a lo mejor entre las instituciones, no sé si formar hoy día, pero sí, a lo mejor comunicación más directa para concretar algo, una coordinación formal y empezar a concretar cosas, a mí me preocupa mucho ya que vemos, se tocaba acá el tema del turismo y la relación con lo que es la protección del patrimonio cultural, eso es tremendamente urgente de tomar medidas, yo creo que es bueno reflexionar, vemos que hay compromiso, que está la conciencia, pero yo creo que es como el momento ya de sentarnos a concretar cosas, esa es la única preocupación, pero muy contenta y creo que la CONADI ha hecho lo que tiene que hacer, no más, estando presente acá. Eso, gracias.

Carlos Araya (Secretario Municipalidad de Ollagüe): Creo que durante estos dos días ha sucedido un hecho que puede dárseles las connotaciones de hito histórico, no solamente en lo que significa, por la calidad de las personas; estoy refiriéndome a todos y cada uno de los participantes en este encuentro, sino que también por el hecho de encontrarse al otro lado de la cresta del mundo para conversar respecto de cómo sentamos las bases, o cómo sientan las bases para poder efectivamente llegar a aunar criterios respecto de los temas que hoy día son importantísimos para el desarrollo de esta región y este país y esta zona andina tan importante. Así entonces el ver cómo un proyecto, que si bien es cierto fue muy modesto en términos de aportes económicos, si se quiere, con una duración más o menos importante en el tiempo, que tienen algunos parámetros con los cuales se puede medir efectivamente el impacto de este proyecto, en tanto su relación efectiva con la comunidad, si esta fue lograda, en tanto lo que hoy día queda en Ollagüe después que ustedes se vayan. Porque esto para Ollagüe también es importante como comuna, en tanto se sentaron a conversar las personas que efectivamente tienen que ver con los temas arqueológicos, antropológicos, cruzados por el desarrollo necesario de la gente de este país, en la cual está involucrado el tema del turismo, ver cómo efectivamente y retrotrayéndome a mis palabras de bienvenida, cómo efectivamente podemos buscar un desarrollo con sustentabilidad en el tiempo para estas comunidades muchas de ellas olvidadas, con una riqueza cul- 
tural inmensa, con una riqueza arqueológica inmensa, con una riqueza paisajística inmensa, que en definitiva debe ser también aprovechada, por qué no; lo que sí debe quedar claro, meridianamente claro, es cual es la forma de intervención que debe llevarse a cabo.

Creo que si bien es cierto quedaron muchas preguntas sin responder, es cierto también que quedaron opiniones contrapuestas que no han sido suficientemente analizadas; es un primer paso para que el trabajo futuro sea un trabajo efectivo, como lo decía la señora Liliana hace un momento, para que las organizaciones, asociaciones y todos aquellos entes que de alguna manera están involucrados en el tema en general puedan efectivamente tener canales efectivos de comunicación en forma tal que todos podamos trabajar unidos.

Para despedirme me gustaría reafirmar lo que en algún momento planteó la señorita Patricia, en tanto, una invitación, es cierto debemos analizarlo, debemos buscar los recursos, pero me encantaría que el próximo año, en una fecha quizás aproximada a esta, pudiera darse un nuevo, el segundo encuentro para que habláramos de patrimonio cultural, para que habláramos de arqueología y para que habláramos de comunidades y su relación. Es ya una invitación creo que hay algunas cosas que afinar, pero sería de sumo importante que pudiésemos ver, evaluar qué fue lo que sucedió desde este día 4 de noviembre del año 2001, a una fecha aproximada en el año 2002; quiero desearles un feliz retorno a sus lugares de origen y agradecerles por haber estado acá, haber aportado con su conocimiento y sus saberes para que este gran tema del patrimonio cultural siga madurando, gracias.

Cristián Catricura: Quiero agradecer a la comunidad quechua por habernos recibido acá, a las autoridades comunales, en sí a los organizadores. Me voy gratamente satisfecho de tan espléndido evento, creo que prioridad de la macrozona norte es específicamente su patrimonio y la relación con la arqueología. Nosotros como corporación estaremos atentos a toda esta relación que se tiene que ir dando de cautelar el patrimonio de los pueblos indígenas. También con la comunidad, que la comunidad es nuestro primer usuario y quien tiene que plantearnos sus problemas para resolverlos. Me voy con un compromiso alto de poder conversar con nuestro director nacional estos temas y también hago un desafío a la Sociedad Chilena de Arqueología de conversar también estos temas con la macrozona sur, de la Octava Región hasta la duodécima región, y también es importante conversar con las demás comunidades indígenas, los demás pueblos que no están presentes acá, el pueblo rapa nui, el pueblo mapuche, mapuche-huilliche, kawaskar y yagán.

Fundamental es la relación que ha tenido el pueblo quechua, atacameño y aymara y colla con la arqueología, esta relación que la han llevado de años y que perdurará en la medida en que sepan proteger y velar por él. El turismo es algo de añadidura, el desafío futuro es la coordinación que tenemos que tener los organismos del Estado para llevar a buen término lo que están solicitando las comunidades y la coordinación que tenemos que tener con las sociedades científicas para una intervención acorde como lo plantearon nuestros hermanos bolivianos y como lo están planteando también en Argentina.

Tenemos que antecedernos a ciertos pasos que están a nivel mundial como en la comisión mundial de patrimonio cultural y esta relación que tenemos que tener nosotros como Estado con las comunidades. Agradezco muy adentro de mi corazón, de mi piuque, muy gratamente sorprendido también con el proyecto de educación intercultural de la municipalidad. Creo que era necesario venir acá y estar acá en la zona para que uno pueda comprender cuál es la relación que uno tiene con su entorno, y esa es la relación que tiene el indígena y si uno no lo ve en terreno es difícil poder establecerlo en un escrito, en una fotografía o quizás por Internet. Muchas gracias y me voy gratamente satisfecho.

Donald Jackson: En nombre del directorio de la Sociedad Chilena de Arqueología quisiera agradecer a los organizadores esta invitación, a la comunidad quechua y pienso que me voy digamos, feliz, contento, y también preocupado.

En primer lugar hemos aprendido a tener un interlocutor válido, creo, y en la medida en que nosotros nos veamos como interlocutores válidos podemos empezar a conversar, a discutir los problemas y dar vías de solución. Yo creo que eso es lo importante, no vernos como comunidades contrapuestas, como entidades confrontacionales, entonces pienso que de esta reunión lo más valioso que ha tenido es eso, por lo menos conocernos a nosotros mismos en la diversidad, saber que nuestro país es diverso y está constituido por grupos de personas, por comunidades de distinto origen, de distinta cultura. En esa medida y en la medida que nos hemos reconocido, creo yo, como interlocutores válidos, podemos empezar a construir un futuro mejor, gracias.

Ricardo Vilca: Bueno yo quiero dar las gracias en nombre de todas las comunidades, de todos los arqueólogos y de todas las personas que vinimos acá, que fue una experiencia muy enriquecedora. Es un hecho inédito que nos hayamos juntado tantas personas, ver el entusiasmo que tienen ustedes es muy grande, porque el entusiasmo es el combustible que hace avanzar a las personas, crecer a sus más a gustos cometidos, desabrigador de mentes clausuradas y por eso me siento muy orgulloso y me siento muy complacido con el pueblo quechua de Ollagüe que haya hecho posible la realidad de juntarnos todos nosotros, con los arqueólogos, con los científicos, con los estudiosos que estudian la ciencia. Muchas gracias de todo corazón. 
